\title{
هبدأ الفصل بين السلطات بين التأصيل التاريخى والواقع السياسى
}

\author{
shel \\ د أحمد على ديهوم \\ مدرس فلسفتر القانون وتاريخه \\ كليتالحقوقـ-جامعتمعين شمس
}




\section{هقدهة}

يعد مبلأ الفصل بين السلطات أحد دعامـات النظام اللديمقراطى، فقد مثل ركيزه

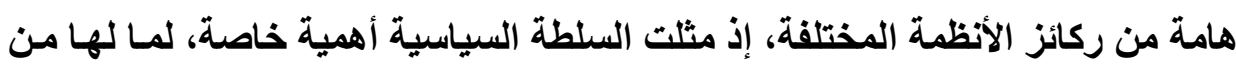

أثر فى تحديد حقوق الإنسان ومقتضياتها'(')

ومبدأ الفصل بين السلطات لم يكتسب أهمية إلا حديثاً، ففى بادئ الامر لم يكن

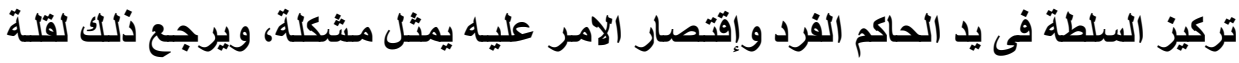

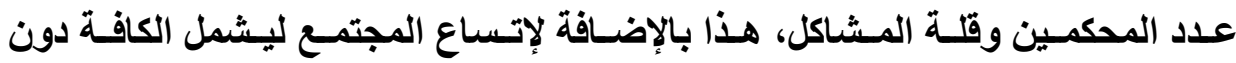

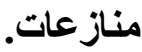

إلا أنه وميع تطور المجتمعات ظهرت الحاجة إلى الفصل بين السلطات، وذلكت ضماناً لحقوق وحريات الأفراد، إذ مثلت السلطة المطلقة مفسده، كمـا أن زيـادة أعباء الهاء الملك المسيطر على مقاليد الامور جعل من الفصل بين السلطات وسيلة لتخفيف عن كاهله (")

ويثور حالياً فى الأوسـاط المحلية فى مصر العليد من التساؤلات حول مبدأ

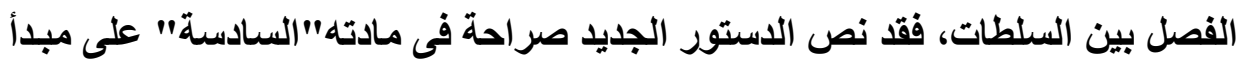
الفصل بين السلطات، إلا أن أحكام المحكمة الاستورية العليا بعدم دستورية العديد من القوانين التى أثارت الجدل، حيث طرحت العليد من الأسئلة حول مفهوم المبدأ وكيفية التئة تطبيقه.

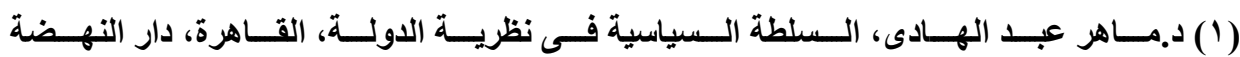

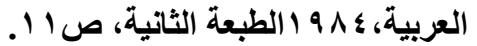
(ץ) د.علاء الدين سعد خطاب، التطور التاريخى لمبدأ الفصل بين السلطات،رسالة دكتوراه، حقوق

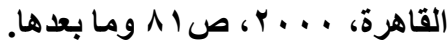

V.r مجلة البحوث القانونيت والإقتصاديت 


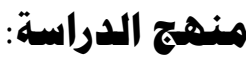

وفى ضوء التعرض لمبدأ الفصل بين السلطات، سوف نتناول المبدأ من الناحية الفلسفية متبعياً المنهج التأصيلى، وذلكت بغيـة الوصسول لأصل المبدأ وبذور نسأته الفكرية، وذلك للوصول للفهم الأمثل له ومن ثم محاولة تطبيقه الأمثل. كما سوف نعتمد على المنهج التحليلى، وذلك بغية الوصول إلى دور المحكمة

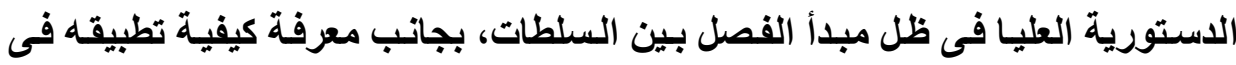
الأنظمة المختلفة.

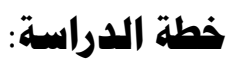

فى ضوء تناولنـا لمبدأ الفصل بين السلطات وأساسـه الفلسفى، بجاتب كيفية

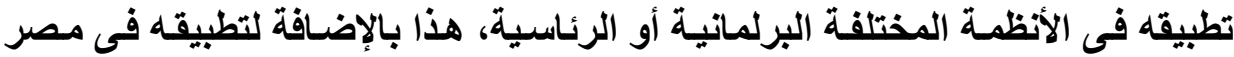
ودور المحكمة الاستورية العليا فى ضوء المبأ.

وسوف نتناول فى فصل أول التأصيل الفلسفى لمبدأ الفصل بين السلطات، لذلك نتنـاول المبدأ فى ظل الفكر الإغريقى رواد الفلسفة من خلال عرض أفكار أفلاطون وأرسطو، كما نتاول المبدأ فى ظل فلاسفة العقد الاجتماعى لوك وروسو ومونتسكيو. ولأن الأفكار الفلسفية لا قيمة لها إلا من خلال تطبيقها، فإنـا نتــاول تطبيق الأساس الفلسفى لمبلأ الفصل بين السلطات فى النظم المختلفة، ولكن لأنتا مجتمع نامى فإنتا نصب إهتمامنا على المجتمعات المتقدمة عسى أن نتطلم منها ونتطور مثلهم، ولكن قبل ذلك نتناول مفهوم مبدأ الفصل بين السلطات. ويناءً على ذلك نتناول المبدا فيما يلى: مبحث تمهيدى: مفهوم مبدأ الفصل بين السلطات. الفصل الأول: الأساس الفلسفى لمبدأ الفصل بين السلطات. 


\section{المبحث التمهيدى \\ هفهوم هبدأ الفصل بين الساطات}

وقد وجد لمفهوم الفصل معنى لغويـاً وأخر إصطلاحياً، أمسا مـن جهـة المعنى اللغوى، فقد عنى الفصل البون ما بين الثيئين، ويقال الفصل هو الحاجز بين الشيئين، فصل بينهما فصلاً فانفصل، وفصلت الشىع فإنفصل، أى قطعه فإنقطع (').

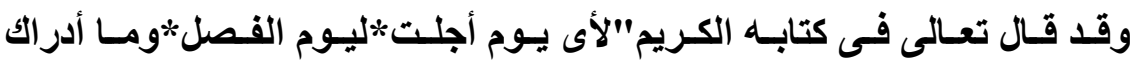
ما يوم الفصل"()، وفى تفسير هذه الأيـات تم توضيح أن يوم الفصل هو يوم التمييز بين المحسن والمسئ أو الفصل بينهمـا، بحيث يجـاز كل بعلـه، ويوم الفصل هو يوم

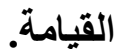

أما المعنى الإصطلاحى للفصل بين السلطات، فقد عنى توزيع سلطات الدولية على هيئات منفصله تستقل كل منها عن الاخرى فى مباشرة وظيفتها، بحيث يكون فى الدولـة ثـلاث سـلطات متمثلـه فـى السلطة التشريعية، والسلطة التنفيذيـة، والسلطة القضائية، وكل منها تقوم بوظيفتها باستقلال عن الاخرى(").

(1) أبن منظور، لسان العرب المحيط، الجزء الرابع، بيروت دار الجليل ودار لسان العرب، 9191 1،

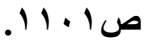

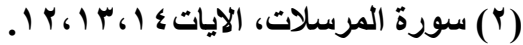

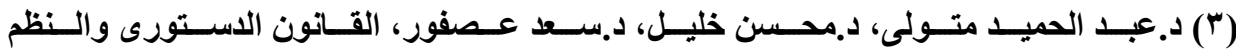

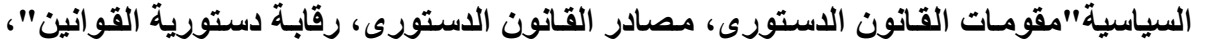

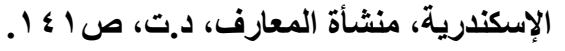


كما عنى أيضا الفصل ذلك المبدأ الذى يقضى بإسناد خصائص السيادة التى يختلف بعضها عن بعض إلى أفراد وهيئات مختلفه ومستقله بعضها عن بعض، بحيث يتم الإسناد من قبل الأمة التى هى مصدر السلطات('). وقد ذهب جاتب أخر من الفقهـ إلى تعريف الفصل بأنهلهـوزيع العمل الحكومى بين جهات ثلاث أخذاً بقاعدة التخصص الوظيفى ومؤداها أن تكون كل جهة متخصصه فى أعمال وظيفه معينة(تشريعية، أو تتفيذية، أو قضائية)، على أن تستقل كل من هذه الهيئات الثلاث فى ممارستها لأعمال وظيفتها عن الجهتين الأخريين بحيث لا تخضع فيه لتدخل أى منهما فى أعمالها و اختصاصاتها"(؟). ومما سبق يمكن القول أن الفصل بين السلطات قد يعنى أحد معنيبين، أولاهمـا سياسى، ويقصد بـه عدم تركيز السلطات فى يـ شخص واحد أو هيئة واحده، بحيث توزع وظائف الدولة على سلطات ثلاث، من تشريعية وتنفيذية وقضائية، بحيث تختص الأولى بإصدار القواعد القانونية المجرده، بينما تلثزم الثانيـة بمهمـة تنفيذها، فى حين تنفرد الثالثة بإنزال كلمة القانون فى المنازعات التى ترفع إليها(").

(1) د. السيد صبرى، السلطات فى النظام البرلمسانى، مجلة القانون والاقتصاد، الأعداد؟، ب، 1، السنة

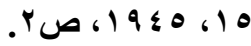

(ץ) سعد حماده، أعمدة الديمقر اطية، المحاماه، العددان r، ا، ، السنة التاسعة والخمسون، يناير-فبراير،

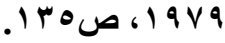

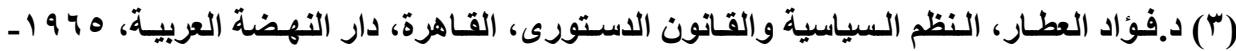

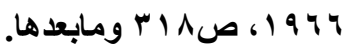

Carre de mabherg:Contribution a la theoriegenerale de 1 etat, paris, 1920, p.38 et.s. 
وثانيهما قانونى، ويقصد به طبيعة العلاقة بين السلطات المختلفة. والفصل وفقاً للمعنى السياسى عد قاعدة من قواعد فن السياسة، إذ أنه ضماناً لحريـات الأفراد ومنعاً للتعسف والإستبداد بالإضـافة للرغبـة فى حسن سير مصالح الاولـة، يجب ألا تركز السلطات فى يـ شخص واحد سواء بطريقة مباشرة أو غير مباثرة، ولـو كان هذا الثخص الشعب أو الهيئة النيابية ذاتهاب('). بينمـا انـصب المعنى القـانونى على توضيح العلاقـة ببين السلطات التى على اساسه برزت النظم السياسية المختلفة من برلمانى ورئاسى، ومجلسى. وقد حدا ذلك بالبعض إلى القول أن مبدأ الفصل بين السلطات لا يعد مبدأ قانونياً بالمعنى الصحيح، إذ أن المعنى القانونى قد أختلف من دولـة إلى أخرى تبعـاً لإختلاف العلماء فى تفسير المبدأ ومن ثم إختلاف الدساتير فى تطبيقها(؟). وقد مثل جوهر مبدأ الفصل بين السلطات دعامتين أساسيتين، أولاهما تتمثل فى تقسيم وظائف الدولة إلى ثلاثة وظائف تثريعية، وتنفيذية، وقضائية، وثثانيهما، تتمثل فى عدم تجميع هذه الوظائف فى هيئة واحده(").

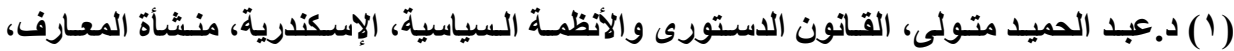

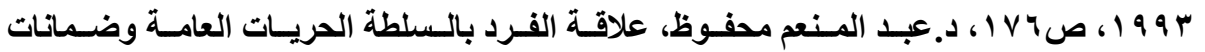

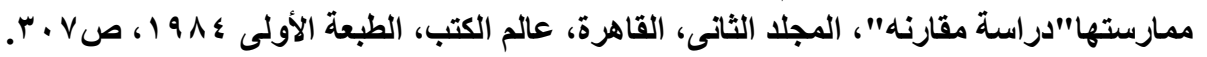

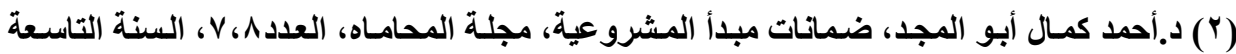

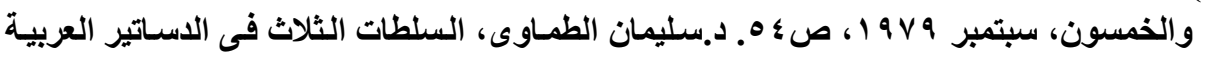

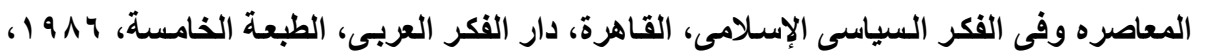

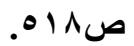

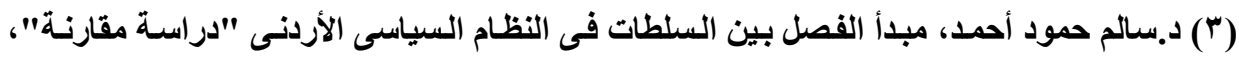

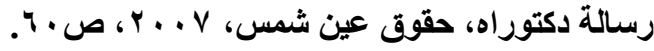


ولما لمبدأ الفصل بين السلطات من أهمية حرص قادة الثورة الفرنسية على

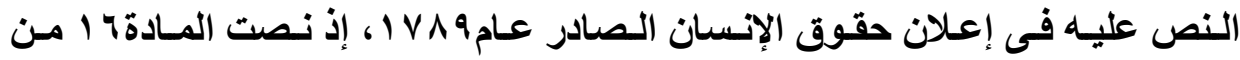
الإعلان على "أن كل جماعـة سياسية لا تؤخذ بمبدأ الفصل بـين السلطات ولاتوفر الضمانات الأساسية للحقوق والحريات العامة هى جماعة بغير دستور". فوفقاً لهذا النص لا يعترف الإعلان بلستور أى دولة لا يتضمن النص على مبدأ

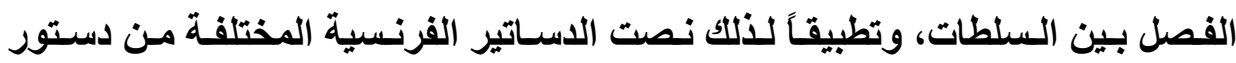

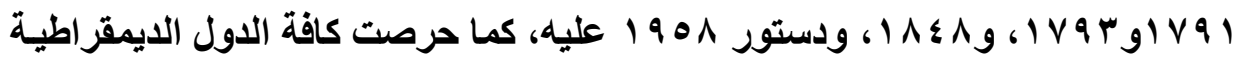
على النص عليه فى دساتيرها('). وبـالرغم مـن الإتفـاق على مفهوم مبـدأ الفصل بـين السلطات وأهميته، إلا أن الفقهاء اختلفوا بشأن تفسيره، فبينما ذهب رأى إلى أن المبدأ يعنى الفصل المطلق بين السلطات، بحيث تمثل كل سلطة من السلطات الثلاث من تنفيذية متمثله في الحكومـة، وتشريعية متمثله فـى البرلمـان، وقضائية متمثلـه فحى القضاء، عضواً فحى الدولـة، ويقتصر دور كل منها على القيام بوظيفتها على استقلال دون تدخل من أحد، ودون وجود أى تعاون بينهم فى أداء هذه الوظائف(").

(1) د. علاء الدين سعد، التطور التاريخى لمبدأ الفصل بين السلطات، رسالة دكتوراه، حقوق القـاهرة،

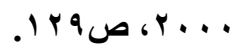

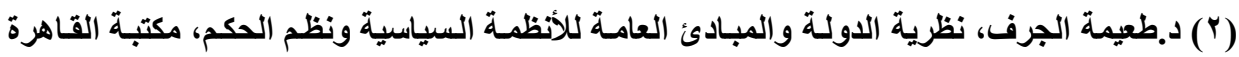

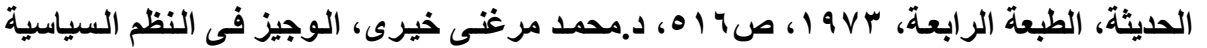

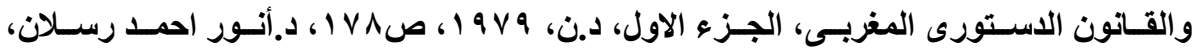

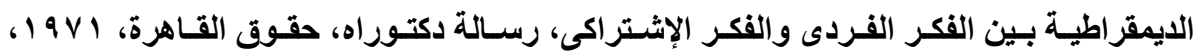

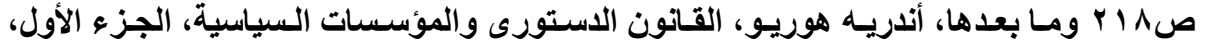

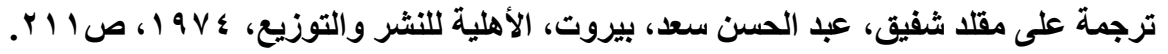


وقـــ أنـتهج هـذا التفسير واضـعى دسـتور الولايـات المتحـده الإمريكيـة عـام

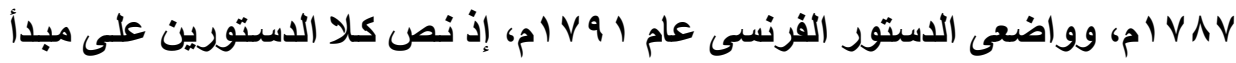
الفصل بين السلطات فى صورته المطلة، وعلى الأخص بين السلطة التنفيذية والسلطة

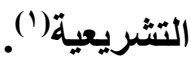

وقد أسس هذا الرأى على أساس أن مبدأ الفصل بين السلطات يعنى التخصص

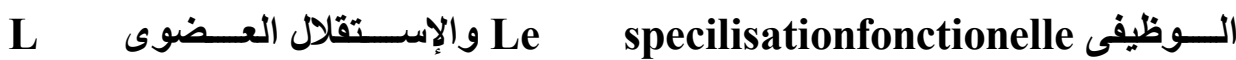
Independence organique لكل اختصاص منفصل عن الأخر، ولا وجود لأى تعاون أو رقابة بينهم(). إلا أن هذا الرأى لم يلق التأييد من قبل العديد من الانصار الذين نـادوا بالفصل

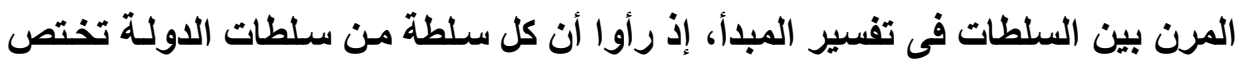
بوظيفة معينة، فى ظل وجود قدر من تعاون بيذهم، وذلك على أساس أنهم ليسوا سوى أعضاء لكيان واحد ألا وهو الدولة. ويتمثل هذا التعاون فى وجود قرر من المشاركة بين هذه السلطات المختلفة فى ممارسـة الإختصاصات هذا مـن جانب، ومـن جاتب اخر في وجود نوعـاً مـن الرقابـة المتبادلة بين السلطات، بحيث إذا تجاوزت إحدى هذه السلطات إختصاصاتها أو تعسفت فى إستعمال حقها أو أساءت إستعماله تصدت لها السلطات الأخرى("). (1) د.سـعاد الشرقاوى، النظم السياسية فى العـالم المعاصـر، الجزء الأول، القـاهرة، دار النهضة

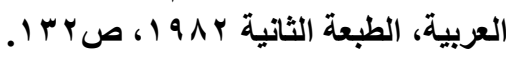

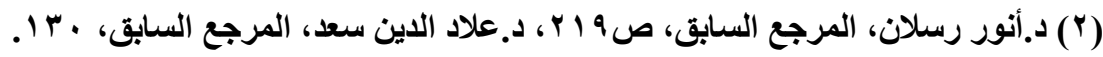

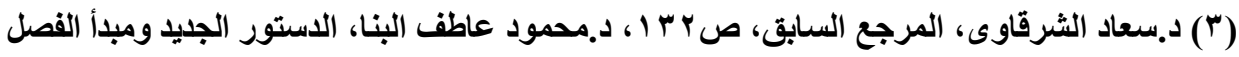

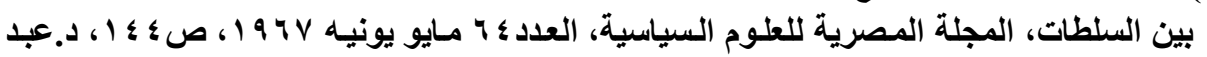

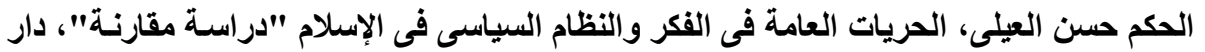

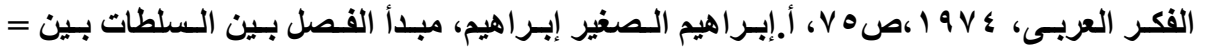


وقد أسس انصار هذا الرأى رأيهم على العديد من الأسس التى تمثلت فى (')

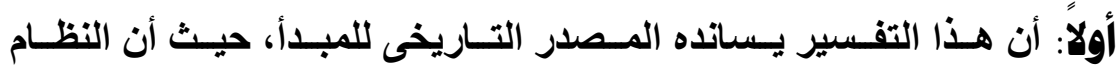
الإنجليزى كان وماز ال يطبق المبدأ بصورته المرنـه، فلم يعرف مطلقاً الفصل المطلق

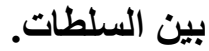

ثانياً: أن الفصل المرن الذى يتصف بالتعاون ووجود رقابة متبادله يؤدى فعلاً إلى عدم تعسف أى من السلطات، وهذا ما يحقق الغرض من المبدأ. ثالثـاً: إن تطبيـق المبـدأ فـى صـورتهـ المطلقـهـ لا يفتـرق كثيـراً عـن تركيـز السلطة من حيث النتائج، إذ تختص كل سلطة بوظيفتها وتنظلق كل منها على نفسها، وهذا ما يؤدى إلى تركيز هذه السلطة فى يـ شـضص أو فئة، وهذا مـا يستتبع التعسف

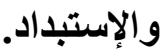

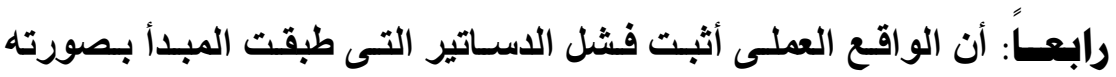

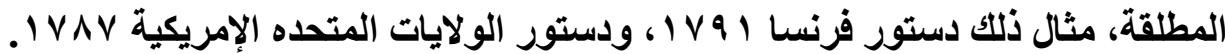

= النظريـة والتطبيق، مجلة إدارة هيئة قضايا الحكومـة، السنة الرابعة والعشرون، العدد الثالث

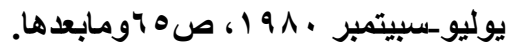

BarthelemyetDuez: Trait de droit constitutionnel, paris, 1920, p.142.

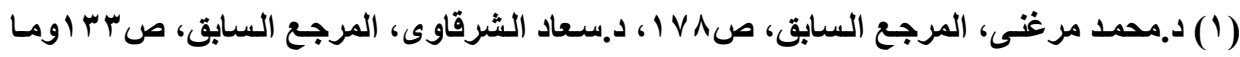

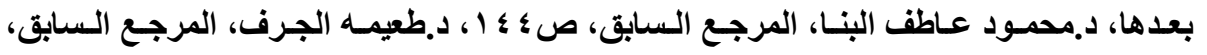

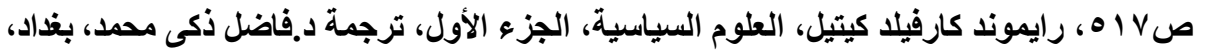

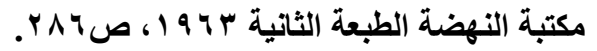

VI. مجلتّ البحوث القانونيت والإقتصاديت 
خاهساً: أن مقتضيات الحياه العملية تستلزم وجود تعاون بين السلطات فيما بينها، إذ تمثل السلطات تروس فى أله واحده هى الدولة، فعلى سبيل المثال تحتـاج السلطة التشريعية لمعاونـة السلطة التنفيذيـة لوضـع التشريعات اللازمسة لمواجهـة الحاجـات الاجتماعية، كمـا تؤدى الضرورات الاجتماعية إلى قيسام السلطة التشريعية

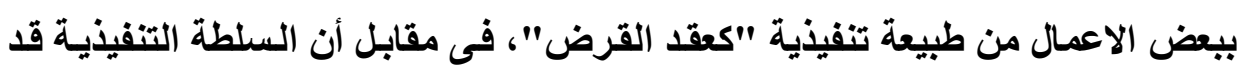
تقوم بأعمال ذات طبيعة تشريعية كإصدار اللوائح. وأيا مـا كـان التفسير فإن مبدأ الفصل بين السلطات يمثل دعامـة من دعامـات

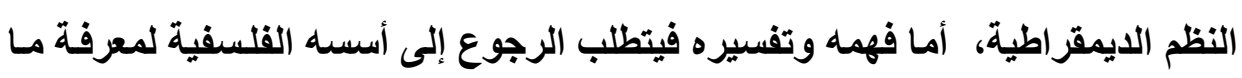

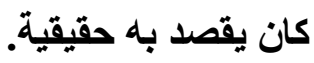




\section{الفصل الأول \\ الأساس الفلسفى لمبدأ الفصل بين السلطات}

ارتبط مبدأ الفصل بين السلطات بأفكار الفيلسوف مونتسكيو، فقد قام مونتسكيو

من خلال أفكاره السياسية ببلورة مفهوم المبدأ، وبالرغم من اتفاق الكافة على ارتباط المبـأ بهـذا الفيلسوف، إلا أنهـم أيضاً لا ينكـرون ظهور المبـدأ بـصور مختلفـة قبـل مونتسكيو.

ففلاسـفة الإغريـق مهـد القلسفة بصفة عامسة، عرفوا فكرة مبـأ الفصل بين السلطات، فنظرية أفلاطون ومن بعده أرسطو قد تطرقت لمبدأ الفصل بين السلطات وإن

كان بصوره جزئية.

كما أن فلاسفة العقد الاجتماعى قد تطرقوا إلى مبدأ الفصل فى خضم نظريتهم السياسية والقانونية، وبـالرغم من معرفة هؤلاء جميعاً المبدأ إلا أن مبدأ الفصل بين السلطات لم يتبلور بصوره واضحه ويكتسب رونقه إلا بكاتبات مونتسكيو. وبناءً على مـا سبق نتـاول الأسـاس القلسفى لمبدأ الفصل بين السلطات للى فلاسفة الإغريق، ثم الأسـاس القلسفى لمبدأ الفصل بين السلطات للدى فلاسفة العقد الاجتماعى، وذلك فيما يلى: المبحث الأول: لاى فلاسفة الإغريق. المبحث الثانى: لاى فلاسفة العقد الاجتماعى. 


\section{المبحث الأول}

\section{لدى فلاسفة الإفريق}

يعـد أفلاطـون وأرسـطو مـن أهـــ فلاسـفة الإغريـق بـصفة خاصـة وفلاسـفة

العالم بصفة عامة، فقد صاغوا أفكار تتضمنت العديد من الأفكار التى ماز الت تطرح إلى الآن.

ولبيـان الأسـاس الفلسفى لمبدأ الفصل بين السلطات كـان من الـلازم التعرض

$$
\begin{aligned}
& \text { لأفكار أفلاطون وأرسطو، وذلك فيما يلى: } \\
& \text { المطلب الأول:أفكار أفلاطون. } \\
& \text { المطلب الثانى:أفكار أرسطو. }
\end{aligned}
$$

\section{المطالب الأول \\ أفكار أفلاطون}

صـاغ أفلاطون نظريـة عن دولـة مثاليـة، وقد تـأثرت كافة أفكاره بتحقيق هذا الهذف، وقد ربط أفلاطون دولته المثالية بفكرة العدالة، هذا بجانب سلطات الفيلسوف

وقد تأثرت فكرة السلطات ووجودهـا بهذه الأفكار، مثلمـا تأثرت أفكار أفلاطون بها، وذلك فى سبيل تحقيق دولته المثالية. 
وبناءً علي ذلك نتناول فكرة العدالة لاى أفلاطون، ثم سلطات الفيلسوف، وذلك فيما يلى: الفرع الأول:فكرة العدالة لدى أفلاطون. الفرع الثانى:الفيلسوف ومبدأ الفصل بين السلطات.

\section{الفرع الأول}

\section{فكرة العدالة لدى أفلاطون}

صاغ أفلاطون فكرته عن العدالة بصورة تختلف عن كثيراً من أقارنه، فقد ذهب إلى أنه يجب البحث عن العدالة فى أجزاء الدولة أولاً، ومن ثم الإتتقال إلى تطبيقها على

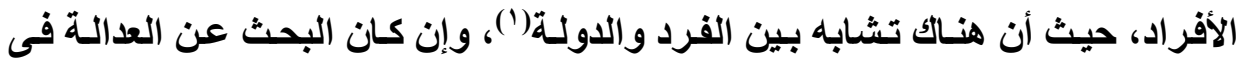
الدولة أولاً يعطى الفكرة وضوحاً وظهوراً عنها فى الفرد().

وتطبيقاً لذلك بدأ أفلاطون فكرته عن العدالة بـالتعرض لأصل الدولـة، مقرراً أن أصل الدولة يرجـع إلى عجز الإنسان عن إشباع رغباته منفرداً، وذلك نظراً لقدراتهـ المحدوده وفى سبيل إثباع الإنسان رغباته وجب عليه تقسيم العمل وتخصيصه. حيث

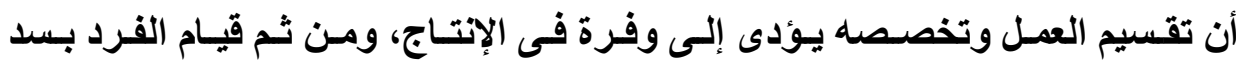
إحتياجاته وبالإضافة للمقايضة لسد رغبات الاخرين(").

M.Humbert:Institutionspolitiques et sociales de 1 antiquite, 1994, p.156. (')

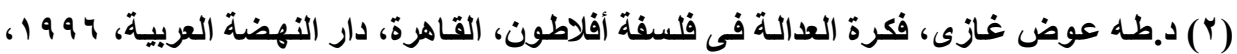

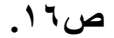
(r) أفلاطون، الجمهورية، ترجمة فؤاد زكريا، القاهرة، المؤسسة العامة للتأليف والترجمة، 1979 1، 
وتتمثل العدالة فى ظل هذا الوضع فى إلتزام كل فرد بالتقسيم والتخصص فى

العمل الذى أوكل إليه، حيث أن الفرد يجب أن يؤدى الوظيفة التى تهيأت لهله ال.

وبموجب هذا التقسيم أوجد أفلاطون أربع فضائل تسود الدولة، أولاهم، الحكمة

وهى تتمثل فى طبقة الحكام، وثانيهم الثجاعة وتتمثل فى طبقة الجند المحاربين أو مـا يعرفوا بالحراس، وثالثهم الإعتدال وتتمثل فى طبقة المنتجين المتضمنه العمال والزراع والتجار، ورابعهم العدالة وتتمثل فى التناسق بين كافة هذه الطبقات، بحيث تقوم كل طبقة بما هو موكل إليها من عمل وفقًا لقدراتهم الطبيعية(†) فالدولة العادلة لاى أفلاطون هى التى يسود فيها التتاسق بين طبقات المجتمع الثلاث، بحيث تسيطر الحكمة المتمثلـه فى طبقة الحكام الطبقات الأخرى، إذ أن طبقة الحكام يسيطر عليها الفلاسفة الذين يمثلون العقل بما يتضمنه من حكمة(")، فطالمـا أن الفلاسفة الذين يمثلـون العقل لهم الكلمـة الفصل يمكن للاولــة أن تصل إلـى أعلى العـ

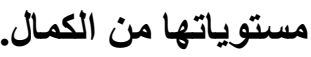

(1) Del vecchio:philosophie du droit, Dalloz, 1953, p.41.

Jean brun: platonet I academie, paris, 1960, p.100 et.s.

Michel villey: la formation de la penseejuridique modern, paris,1968, p.25.

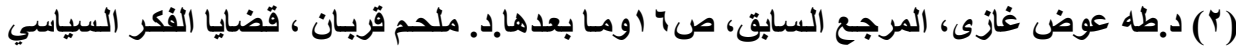

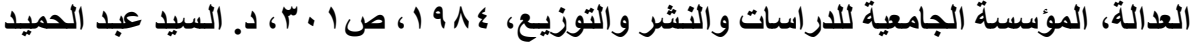

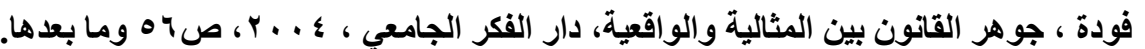
(3) Jeanniere"Abel": Lire platon, Edition de Aubien, p. 242. 
أما وظيفة الحراس فتقتصر مهماتها فى الدفاع عن الدولة، أمسا طبقة المنتجين

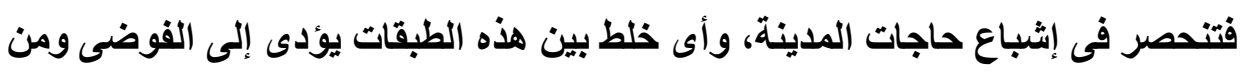
ثم يعد ظلم، وذلك نتيجة للتنافر فيما بين هذه الطبقات الثلاث (') وقد ذهب أفلاطون أن الدولة يوجد بها عناصر تقابل النفس البشرية(")، فوجد عنصر الثهوه، وهو المتمثل فى إثباع رغبات الأفراد من كافة الضرورات الحياتية، و هذا ما تقوم به طبقة العمال والزراع.

كما وجد عنصر الشرف وهو مـا يعكس الطابع الروحى للاولـة، ويتمثل فى في

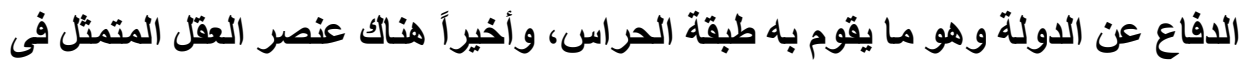
الفهم و المعرفة والذى تمثله طبقة الحكام ("). ومفاد ذلك أن كل طبقة من هذه الطبقات لها وظيفة محدده، ويجب أن تقوم كل طبقة بوظفتها على أكمل وجه، وقد أدى ذلك إلى تقسيم أفلاطون المجتمع تقسيم صارم

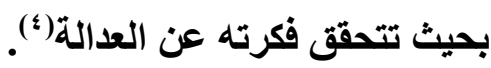
وفى سبيل إقناع الأفراد بهذا التقسيم الطبقى الصارم، ذهب أفلاطون إلى أن هذا

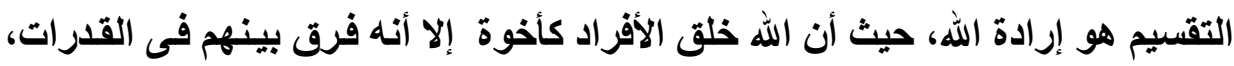

(1) د.فؤاد زكريا، جمهورية أفلاطون، الهيئة المصرية العامة للكتاب، القاهرة، هـ9 1 ، فقرة ب ؟ ؛ ـ

(ץ) د.محمد على أبو ريان، تاريخ الفكر السياسى"الفلسفة اليونانية"، ج ا ، الإسكندرية، دار المعرفة

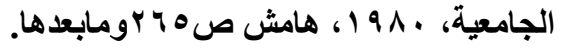

(3) J.Maillet:Histoire des institutions et des faitssociaux, dalloz, 1956,p.118

P.c.Timbel: Histoire des institution, dollaz, 1966, p.18.

$$
\text { (צ) د. طه عوض، المرجع السابق، ص • ب ومـا بعدها. }
$$


فليس الكافة من ذات المعدن أو بذات القدرات، فهناك من هم من معدن الذهب، وهؤلاء هم من يتمتعون بسلطة الأمر والنهى، وهناك من هم من الفضة، وهؤلاء هم الحراس، وهنالك من هم من النحاس وهؤلاء هم المزارعين والحرفيين(').

وقد أضاف أفلاطون أن الربط بين تقسيم العمل بين الطبقات والعدالة يكمن فى

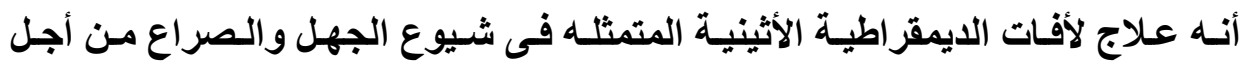
السلطة (؟)، فسيطرة طبقة الفلاسـفة بإعتبارهـا الطبقـة الحاكمـة تقضى على الجهل والصراع من أجل السلطة.

ومفـاد مـا سـبق كلـه أن أفلاطون فى سـبيل تحقيـق العدالـة قسم المجتمـع إلى طبقات، وحدد لكل طبقة وظيفة محدده تقوم بها، بحيث تسيطر الطبقة الحاكمة على الأمور، وهذه الطبقة تسبطر عليها فئة الفلاسفة الذين يحملون مفاتيح المعرفة. ويرجع هذا التقسيم لاى أفلاطون إلى أنه رأى فيه تحقيقاً للخير العـام ونظريته عن المدينة المثالية(")، هذا بالإضافة لعثقه للنظام بصفة خاصة، فقد هدف من تقسيمه المغلق للطبقات أن ينشأ مجتمعاً ثابتاً تكون قد أقتلعت منـه قوى التغيير، حيث تتناستق

$$
\text { (1) (1) المرجع السابق، ص • بارمابعد ها. }
$$

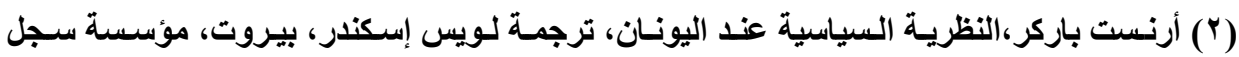

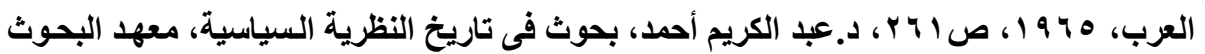

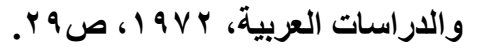

(3)Albert Brimo:Les grands courants de la philosophie du droit et d l etat, paris, 1967 , p. 73.

Henri Rommen: Le droit naturel, Traduction par Emile Marny, paris, p.29.

VIA مجلت البحوث القانونيتّ والإقتصاديت 
وحدات المجتمع بصوره كلية، فقد ساد لايه مبلأ أن أى تغيير فى أى وقت ولأى غرض

يجب الإبتعاد عنه، فالتغيير معناه الإضمحلال و الكمال عنده معناه إنعدام التطور (').

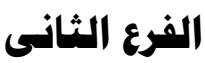

\section{الفيلسوف وهبدأ الفصل بين السلطات}

أنعكست أفكار أفلاطون عن العدالة على العديد من أفكاره القانونية والسياسية،

فقد قام على أثر مفهومه عن العدالة بجعل السلطة فى يد طبقة الحكام فقط، ليس هذا فحسب بل أنه قصرها على الفلاسفة، وهذا ما أثر على تعريفه لرجل السياسة ووظيفته. وتكمن البداية فى هذا كلـه أن أفلاطون رأى أن الأسساس الوحيد لحكم الدولية أو

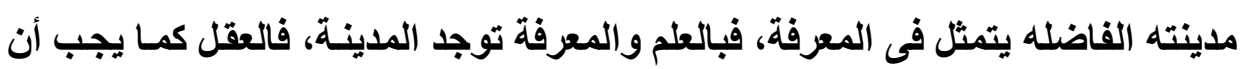
يحكم الإنسان فإنه يجب أن يحكم الدولة، وعقل الدولة متمثل فى الفلاسفة أو فى الحكام

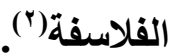

"ومفاد ذلك أن الدولة تثابه الفرد في الفضائل وفي وجوب خضوعها لفضيلة الحكمة، كما تتشابه العدالة لديهما في انها توافق وتتاسق القوى المختلفة في علاقاتها

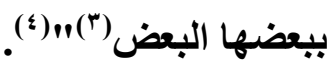

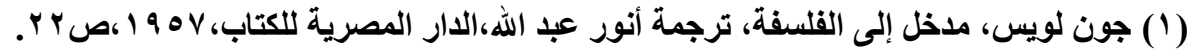

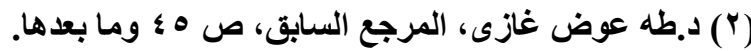

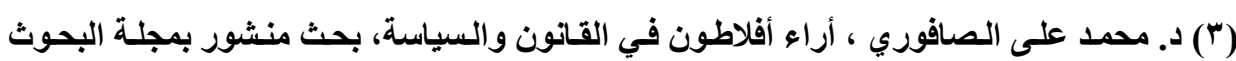

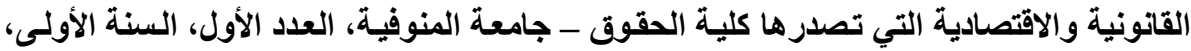

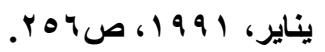

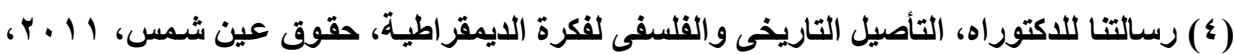

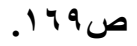

VI9 مجلة البحوث القانونيت والإقتصادية 
وقد أضاف أفلاطون أن الحاكم الفيلسوف هو من ينشأ الحلول العادلة ومن ثم القو اعد القانونية، وذلك من خلال إستّلاهما من عـالم المثل، فوفقاً لر أيه هنـاك قانون مثالى يعد المرجعية للقوانين الوضعية، هذا القانون المرجعى لا يمكن معرفته إلا من خلال الفيلسوف، وفى ذلك قيل عن أفلاطون (')

"Platon oppose le loivraie et juste a la loi positive et il fait de la premiere la masure de la second et le critere de la rectitude. Cettevraieloi, cevrai droit viventdans le monde des idees."

وينـاءٌ على ذلك فبإن الفيلسوف يجب أن يحكم، وتأكيداً لـذلك ذهب إلى أن السياسة فن، فهى ليست مسألة تكتسب بالخبرة وتتبلور فى بضعة قوانين تحكم الدولة وتلزم الكافة، بل هى حكم وإدارة والإدارة فن، لذا فإن رجل الحكم مثل الفنان. وقد أطلق أفلاطون هذا اللقب "الفنـان" على رجل الحكم فى الجمهورية وفى

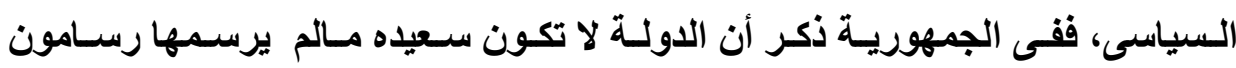
ينسخون عن أصل إلهى (") وقد قال في ذلك"مـا لم يتول الفلاسفة الحكم في الدول أو يتحول من نسميهم

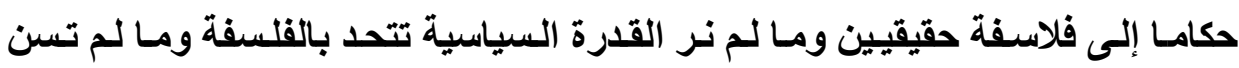


قوانين دقيقة تبعد من لم يجمعوا بين هاتين القوتين فلن تنتهي الشُرور من الدول بل

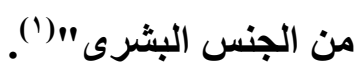

أمسا فى السياسى فقد شبه رجل السياسة بحائلك النسيج الذى يجب عليه

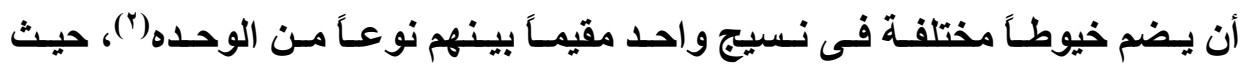

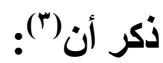

"le roiestdonccomme un tisserand qui droit unirdans un meme tissue des fils de couleurs et de qualities differents "

فمفاد ذلك أن رجل السياسة يجب عليه أن يوحد بين عناصر المجتمع المختلفة، وهو فى ذلك يشبه الفنان، وفى سبيل ذلك قام أفلاطون بإطلاق سلطاته، حيث ذهب إلى أن الفيلسوف لا يخضع للقانون، مبرراً ذلك أن عمل الفنان يتولد من ذاته وهو فى ذلك

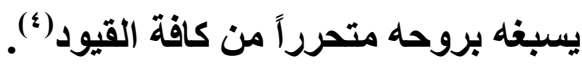

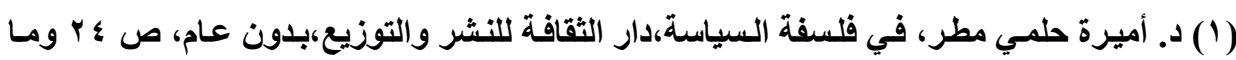

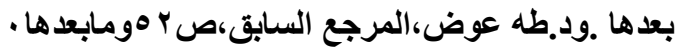

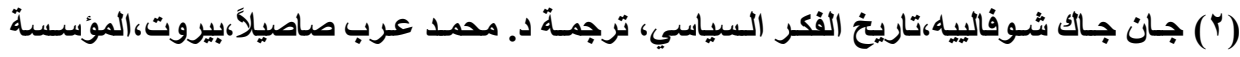

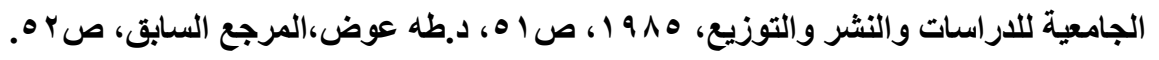

(3) Jean brun: op cit. p.112.

$$
\begin{aligned}
& \text { (؛) أرنست بـاركر، المرجع السابق، ص IV IV ومـا بعدها، د.عبد الكريم أحمد، المرجع السابق، }
\end{aligned}
$$

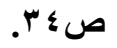

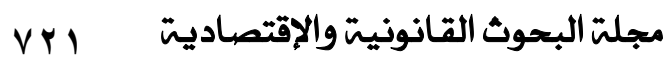


كمـا أن الفيلسوف لا يتوقف عمله على رضـاء أفر اد المجتمع، حيث أنها يملك المعرفة العليا، فطالما أنه يسترشد بالمعرفة فإنهه لا يسمح لأحد بالتدخل، وإن كـان من الأفضل له أن يقنعهم ولكن هذا لا يعد إلتزامـاً عليه('). وقد أدت هذه الأفكار لاى أفلاطون إلى القول بإعتناقه الحكم المطلق، فأفلاطون لـ يعترف بمبدأ سيادة القانون فى ظل حكم المعرفة، فالحكام فى سياق فصلهم فى المنازعات يستلهمون روح العداله من القانون المثالى، لذا يجب ترك قدر من الحريـة فـى نشـاة القـانون الذَى يحقق العدالـة، فالحكـام لا يخضعون إلا للقـانون الــى يحقق العدالة، وبالتالى لا دور للقانون الوضعى لديه فى ظل هذا الحكم(). ومفاد ذلك أن القانون لاى أفلاطون ليس ما تصدره السلطة من قواعد، بل هو القواعد التى يقوم بإستنباطها الفلاسفة لتحقيق العدالة بمفهومها الواسع لدى تحقيق

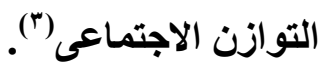

ونتيجة للحكم المطلق الذى نتج عن أفكار أفلاطون عن العدالة، لا يمكن أن يكون هناك مجال لمبدأ الفصل بين السلطات، حيث أن الفلاسفة سيطروا على الحكم بصفة مطلقة، وقد ظل أفلاطون أمينـاً لهذا الفكر فى الجمهوريـة والسياسى، إلا أنهـ قد عدل عن أفكاره فى "(القوانين"، وإن لم يعد ذلتك تخلى عن نهائى حكم الفيلسوف،

(1) Ellul"Jacques": Histoire des institutions, tome premier, 1955, p. 102. Impert "Jean": Le droit antique, 3e edition 1976, p.43.

Albert Brimo: op .cit. p.23.

(3) M.Villey: op . cit , p.23. 
إنماأعتر (فاً منـه بصعوبة وصول الفيلسوف للحكم فعليًا، وهذا مـا رتب أعترفه بدولـة القانون كحل بليل لحكم الفلاسفة(')

وقد غير أفلاطون أفكاره فى "القوانين" عن "الجمهوريـة" من عدة وجوه،

فمن ناحية أولى أعترف بالعادات والتقاليد التاريخية، كما أعترف بضرورة المؤسسات

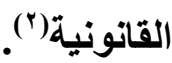

ومن ناحيـة أخرى أقر الحكومـة الاستورية تحت حكم القـانون، وذلك بخـلاف

"الجمهورية" التى أعترف فيها بحكومة فردية بدون قانون(").

ومن ناحية ثالثه فقد أعـاد أفلاطون تنظيمه للمدينة من خلال توسيع المجتمع

السياسى و إشر اكه لكافة المواطنين فى إدارة شئون المدينة(؛).

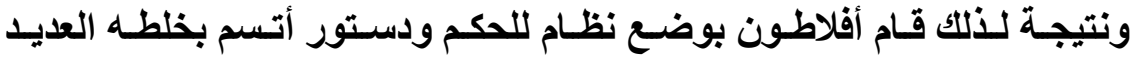

من مميزات الأنظمة المختلفة، حيث قام هذا النظام المختلط على العديد من عناصر ومبادئ مختلفة، بحيث يصل فى النهاية إلى الإنسجام والتوافق بين القوى المتعارضـة،

جاعلاً كل منهم صمام أمسان للأخر (0)، وهذا مـا يقترب من مضمون مبدأ الفصل بين إنى

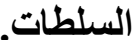

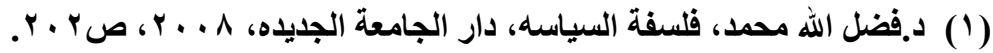

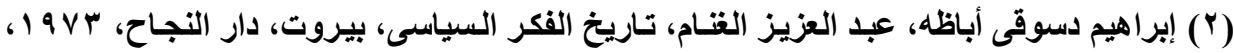

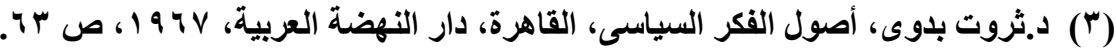

T.A.Sinclain: Histoire de la penseepolitiqueGreceque,paris, 1953, p. 110.

(4) Sabine: A History of political theory, New York, holt, 1946, p.81.

(0) د.ثروت بدوى، المرجع السابق، صلآ وما بعدها.

NYr مجلتّ البحوث القانونيت والإقتصاديت 
وتفصيل هذا النظام أن أفلاطون خلط بين نظامين هما النظام الملكى والنظام

الايمقراطى، فبالرغم من قيامهما على أسس مختلفة، حيث أن النظام الملكى يقوم على السلطة بينما النظام الديمقراطى يقوم على أساس الحريـة(')، إلا أن أفلاطون سـى إلى

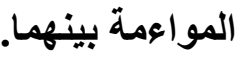

ويرجـع ذلك إلى أن إنهيـار اللدول يعود إلى أحد سببين إمـا إستبداد الملـوك بالسلطة، ومن ثم استبعاد الأفراد وعدم مشاركتهم فحى الحكم، ممـا يجعلهم متحفزين للتخلص من طبقة الحكام، وإمـا استخدام الأفراد لحرياتهم بصوره مفرطه تؤدى إلى الإستهانه بالسلطة ومن ثم القوانين(`)

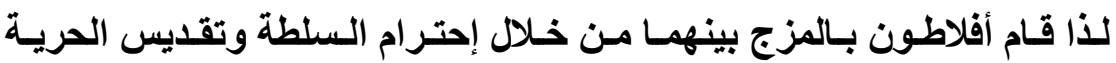
وحمايتها، وتحقيقاً لذلك قام بتقسيم المجتمع إلى أربع طبقات تثنترك جميعاً فى الجمعية العمومية، وبجانب الجمعية وجد مجلس "Boule"، يتكون من " . بץ" عضواً يتم إنتخابهم، بحيث ترشـح كل طبقة ، 1 1 شخصاً يتم اختيـار ، 9 من بينهم عن طريق

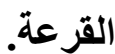

ويجاتب هذه الهيئات وجد الحكام، وهم فيما بينهم يكونـوا هيئات، فهنـاك هيئة الحراس على القوانين ويتم اختيار هم من قبل الجميـة العمومية عن طريق الإنتخـاب، وهناك القضاه الموكول إليهم الفصل فى المنازعات الجنائية والمدنية ويتم إختيارهم

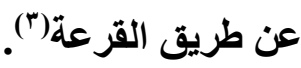


وقد وضع أفلاطون مبادئ تنظم عمل هذه الهيئات بما يحقق المساواة والحريـة السياسية، حيث وضع مبأ انتخاب الحكام، ومن جهة اخرى ساوى بين الطبقات الأربع فيما يخصص عدد المقاعد المخصصه لهم فى المجلس النيابى، إلا انه أثنترط في الني

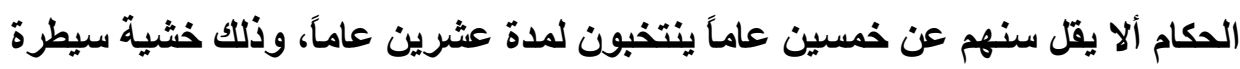
عنصر الثباب الذى يدعو إلى التجديد (') ومفـاد مـا سـبق كلـه أن أفلاطون فـى بدايـة نظرياتـهل لـم يـؤمن بفكرة الفصل

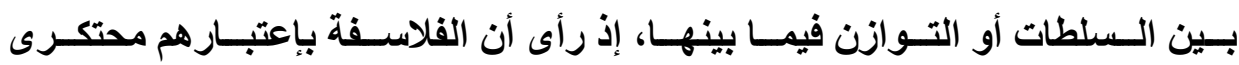

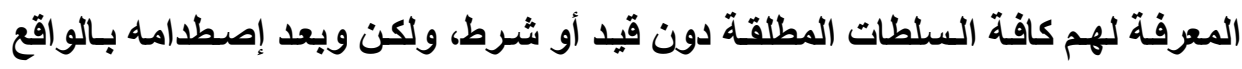

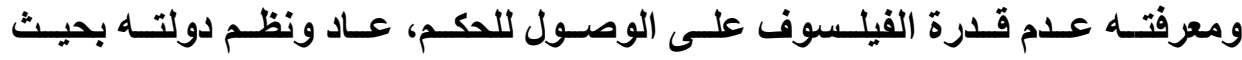
تكون السيادة فيـه للقـانون، ويحيث تكون هنـاك مساواة وحريـة بين هيئات الحكم المختلفة.

لذا يمكن القول أن أفلاطون مهذ لمبدأ الفصل بين السلطات فى أواخر أفكاره، وذلك من خلال إقامة التوازن بين هيئات الحكم وخضوعهم كافة للقانون.

\section{المطاب الثانى}

\section{أرسطو}

عرف أرسطو تقسيم سلطات الدولة، وذلك بالرغم من أن الكثيرين يلحقون هذا

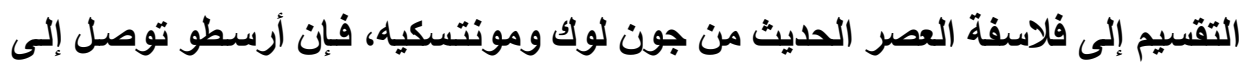


تقسيم السلطات وذلك تأسيساً على خبرتـه السياسية الإغريقية، وإن كانت تختلف عن الخبره السياسية الحديثة) (')

ولكن هل عد ذلكت فصلاً بين السلطات، وإن كان كذلك فهل كـان هذا الفصل مرنـاً ام جامداً، وبناءً على ذلك نتناول تقسيم السلطات أولاً، ثم العلاقة بين السلطات ثانياً، وذلك فيما يلى:

الفرع الأول: تقسيم السلطات لاى أرسطو. الفرع الثانى: العلاقة بين السلطات الثلاث.

\section{الفرع الأول}

\section{تقسيسم السلطات لدى أربسو}

ذهب أرسطو إلى تقسيم سلطات الدولة إلى ثُلاث سلطات، فقد رأى أن كل دولة تتضمن ثلاث اجزاء، فإن أحسن الشارع تنظيمها وعملها والبعد عن الأهواء، حسنت الدولة بالضرورة، ولا يوجد فرق بين الدول فى هذا إلا فيمـا يخص إختلاف العناصر

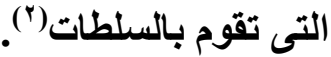
ويرجع هذا التقسيم الثلاثى للدى أرسطو إلى أنسه رأى أن الدولـة تقوم بالعديد من الانشطة، وهذه الأنشطة تتمثل فى ثلاث هى (")

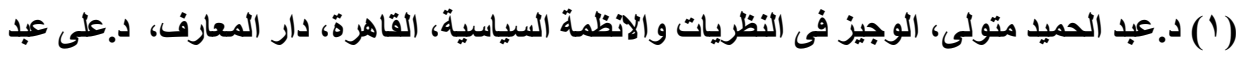

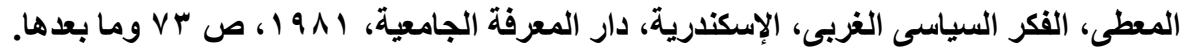

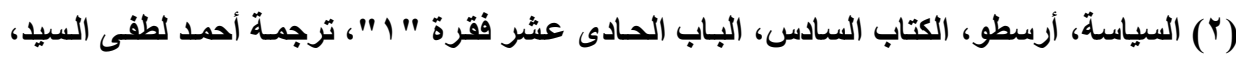

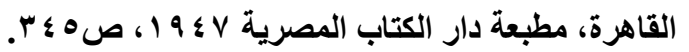

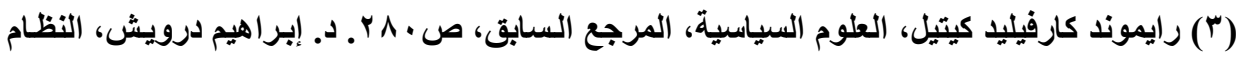

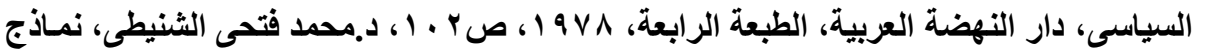

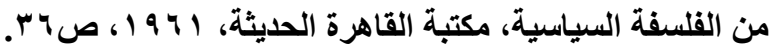




\section{Deliberation \\ أولاً: المداولة أو الفصص \\ commandent \\ ثانياً:الاهمر \\ justice \\ ثالثا:القضاء}

Legislation " وقد مثلت وظيفـة المداولـة أو الفحص السلطة التشريعية

power" ، وهى ما مثلت جمعيـة المواطنين للى الإغريق، ولكن لم تقتصر وظيفتها على مجرد سن التثريعات، بل أمتد اختصاصها ليثمل النظر فى كافة قرارات الحكومـة وسياستها، وذلك من أمور الحرب والسلام وإبرام المعاهدات وفسخها وأحكام الإعدام والنفى والمصادرة ومحاسبة الحكام (').

أما وظيفة "الامر" فقد مثلت السلطة التنفيذية"Executive power"، وقد رأى أرسطو فى هذه السلطة أنها تعكس حجم الدولة، بحيث أنها فى الدول الكبرى يجب أن تتضمن العديد من الإدارات التى يكون لها اختصاصات تنفرد بها، بمـا يرتب عدم شغل فرد بعينه الوظيفة ذاتهـا إلا بعد فترة طويلـه، أو لا يشغل الفرد الوظيفة إلا مره واحده، وذلك بخلاف الدول الصغرى التى لا يتحقى فيها ذلك لندرة الموظفيين، الأمر الأى يؤدى إلى تركيز العديد من اختصاصات السلطة التنفيذية فى يد عدد محدد من

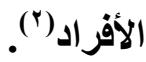

وقـــ أوكـل أرسـطو مهمـة السـلطة التففيذيـة إلـى أفـراد بعيـنهم، وإن أختلفـوا بإختلاف الحكومـات، ففى الحكومـة الإرستقراطية توكل السلطة إلى أفراد مستنيرين،

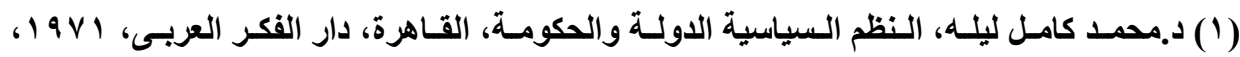

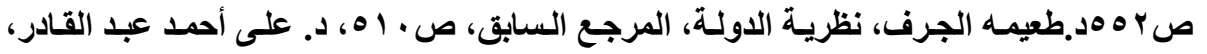

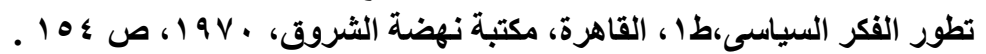

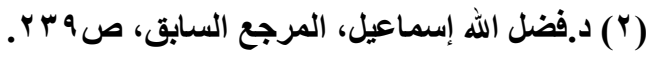


بينما فى الحكومة الأوليجاركية توكل إلى أفراد أثرياء، أما فى الدكومة الدستورية توكل

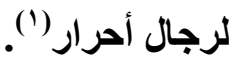
وقد أثترّط أرسطو ثُلاث عناصر لقيام السلطة التنفيذية بمهامها، أول هذه العناصر الناخبون، وثثانيهم المنتخبون، وثُالثهم وسيلة التعيين، وهذه العناصر تتباين من نظام لأخر، فإختيـار الحكام إمـا أن يتم بواسطة كافة المـواطنين أو بواسطة فئسة

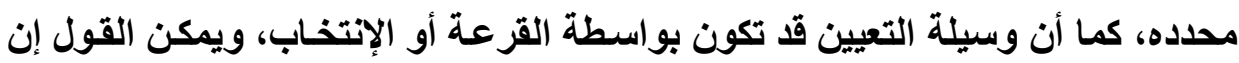
إختيار الحكام وفقاً لأرسطو يمكن أن يتم بأى من الطرق التالية(؟): 1 - بواسطة كافة المواطنين بطريق الإتتخاب. r - بواسطة كافة المواطنين بطريق القرعة. ץ- بواسطة فئة من المواطنين بطريق الإتخاب. ع - بواسطة فئة من المواطنين بطريق القرعة.

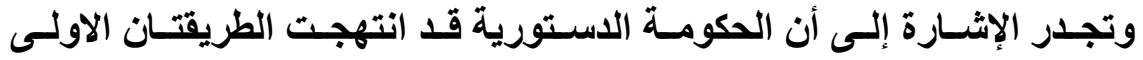

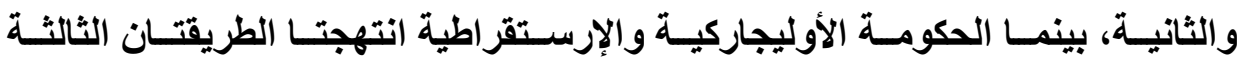

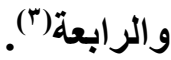
أمسا وظيفة القضاء فتمثل السلطة القضائية "Judiciary power"، وقد تمثلت هذه السلطة فى المحاكم التى تقوم بتطبيق العدالة بين الأفراد من خلال تطبيق

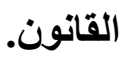

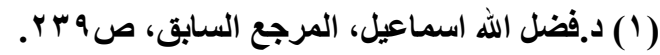

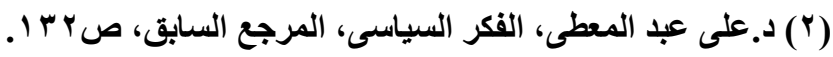

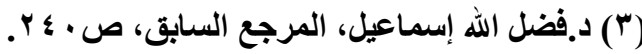




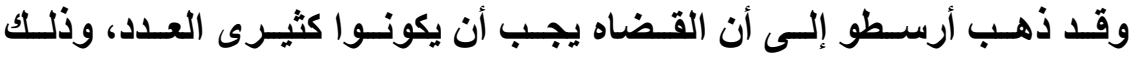

تأسيساً على أنسه مـن الصعب إفساد الجماعة كثيرة العدد بينمـا يسهل إفساد الفرد، فالقاضسى الفرد حين يمتلكهـ الغضب فبإن من السهل التـأثير على حكمـه، فحتمـاً يوأثر الغضب على الحكم، بينما الجماعة من الصعب أن يتملكهم الغضب جميعاً أو أن يخطئوا

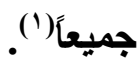
وقد ذهب أرسطو إلى أن القضاه يعينوا بواسطة الإتتخاب، إلا أنهم يختصون بالفصل فى القضايا بواسطة القرعة أو الإنتخاب، حيث إن تحديد من يقوم من القضاه بالفصل فى الدعاوى يتحدد بإحدى هاتين الوسيلتين(؟) وقد قسم أرسطو المحاكم إلى ثمانية انواع، أختصت كل منها بنظر نوعا محدداً من القضايا، وقد تمثلث هذه المحاكم فى (): 1 ـ محكمة لتصفية الحسابات العامة. r - محكمة للفصل فى الأضرار التى تلحق بالدولة. r- محكمة للفصل فى إنتهاك الحرمات الاستورية. ع ـ محكمة لطلبات التعويض من الأفراد والحكام. هـ محكمة تختص برفع القضايا المدنية الهامة. 7 - - محكمة لقضايا القتل.

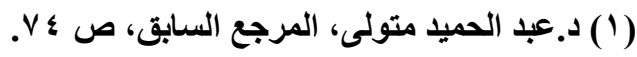

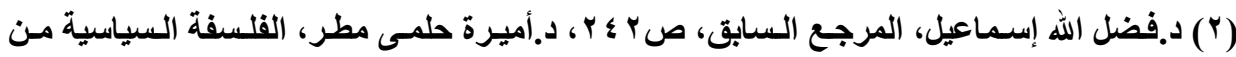

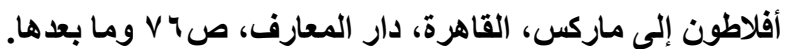

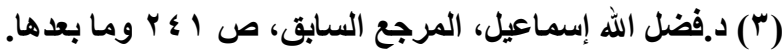




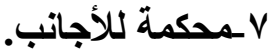

^ـمحكمة للقضايا الجزئية، أى أنها تختص بالقضايا ذات نصاب مالى معين.

ومفاد ما سبق كله أن أرسطو قسم سلطات الدولة إلى ثلاث، تمثلت فى تشريعية

وتنفيذية وقضائية، أى أنه عرف مبدأ الفصل بين السلطات، وإن ذهب البعض إلى أنه لا

يمكن الإستناد على أراء أرسطو كأساس لنشأة مبدأ الفصل بين السلطات، وذلك تأسيساً على أنه لم يقصد من توزيعه السلطات سوى تحديد مظاهر هيئات الدولة، وذلك دون الذهاب إلى وجوب توزيع وظائف الدولة على أساس التمييز بين الوظائف التى أختصت بها كل هيئة من هيئات الدولة.

وتطبيقاً لذلك لـم يمـانع أرسطو فـى قيـام عضو الهيئة التشريعية بعدل عضو

الهيئة التنفيذية أو بعمل عضو الهيئة القضائية، لذا أمكن القول أن أرسطو لم يتعرض

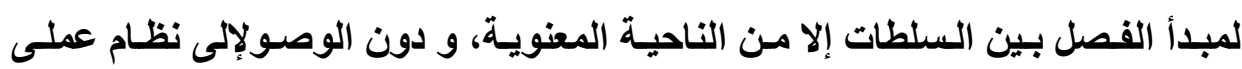
يطبق فى الدولة) (1)

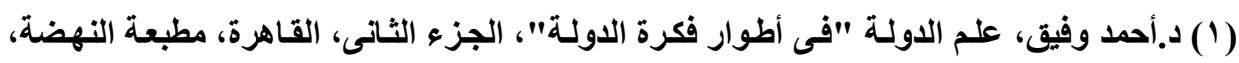

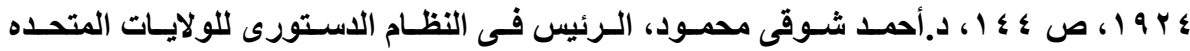

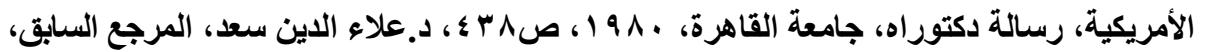

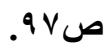

Carre de Malberg: op .cit. t.2, p.2.

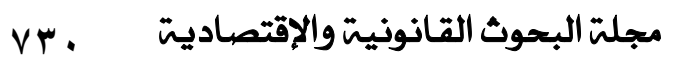




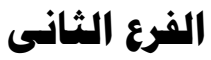 \\ العلاقة بين السلطات الثلاث}

أرتبطت فكرة الفصل بين السلطات ومن ثم العلاقة بينهمـا، بإختيار نظام معين

للاولة، وذلكك من ضمن مائة وثمانية وخمسين دستوراً لمختلف البلادوفقاً لأرسطو -، وفى سبيل ذلك قام أرسطو بتقسيم الحكومات على أسساس احد معيارين، أولاهمـا كمى، ولئ،

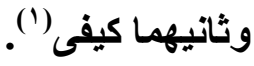

فتأسيساً على المعيار الكمى أو العددى، فقد تكون السلطة فى يد فرد واحد، كمـا

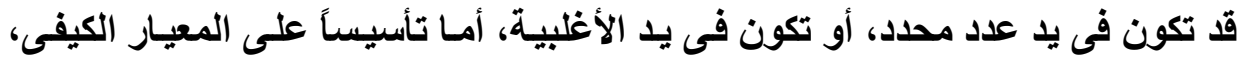

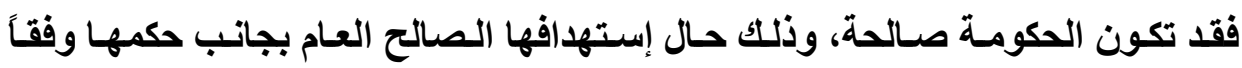
للقانون وبرضاء المحكومين، وقد تكون حكومة فاسدة وذلك حال عدم حكمها بالقانون

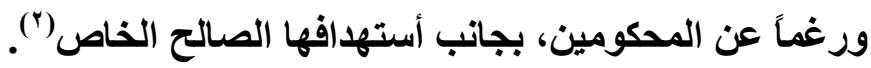
ويناء على هذين المعيارين قسم أرسطو الحكومات إلى "الأشكال التالية("): 1 - الملكية، وهى حكومة فرد واحد لكنه يسعى لتحقيق المصلحة العامـة ويدير

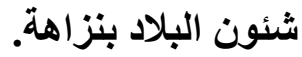

(1) د.ثروت بدوى، أصول الفكر السياسى والمذاهب السياسية الكبرى، القاهرة، دار النهضة العربية،

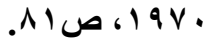
(r) د.فضل الله إسماعيل، المرجع السابق، ص ابrابومابعدها.

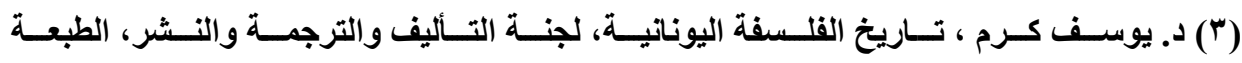

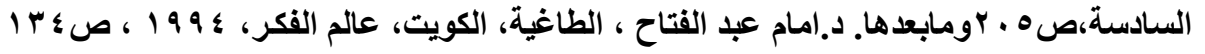


Y - الطغيـان، ويقابـل الملكيـة حيث يسيطر عليها فرد واحد لكنـه يسعى لتحقيق مصالحه الثخصية وإهمال المصلحة العامة.

rـ الأرستقراطية، وهى حكومة الأقلية الفاضلة حيث تسعى لتحقيق الصالح العام . ع ـ الأوليغارشية"الأوليجاركية"، وهى المقابلة للأرستقراطية حيث يسيطر على الحكم الأقلية الغتية الذين يسعون لتحقيق مصالحهم الشخصية.

هـ الديمقر اطيـة، وهى حكومـة الأغلبيـة الفقيرة التـي تتمتـع بالحريـة والمساواة والعمل على تحقيق المصلحة العامة.

7ـ الايماغوغية، وهى التي تقابل الديمقراطية حيث تسيطر الأغلبية الفقيرة ولكن

لتحقيق مصالحها الخاصة(')

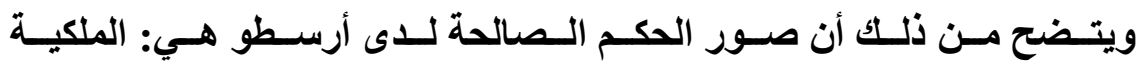

والأرستقراطية والديمقراطية، أما غير ذلك فهي صور فاسدة للحكم. وبالرغم من رأيه بأنـه لا يوجد نظـام بعينه هو الأفضل ولكن الأفضل يتحدد بحسب ظروف كل مجتمـع ودولة(؟) إلا أنه فضل الحكم الملكي الذي يسيطر عليه فرد عـادل ذو فضيلة وحكمـة،

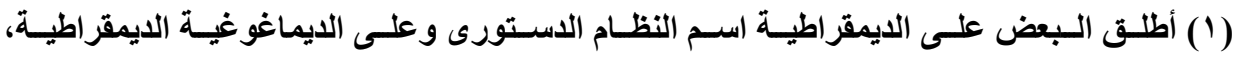

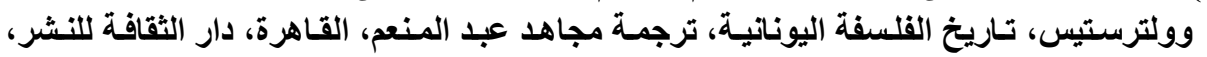

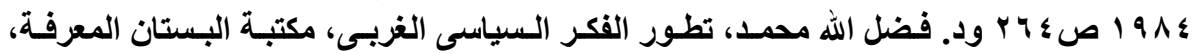

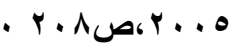
(ץ) د. احمـد أمين ود. زكى نجيب ، قصة القلسفة اليونانيـة، مكتبـة النهضة المـصرية، الطبعة

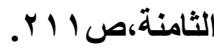


وإن كـان مـن الصعب وجـود مثـل هذا الشخص- مثنل أفلاطــون- ويلـى هذا النظسـام الأرستقر اطي ثم الايمقراطى" (1")

وإن كانت الحكومة الإرستقراطية لا يمكن ضمان سعيها إلى تحقيق الصالح العام

دائمساً، فقــ تتحرف لتحقيـق مـصالحها الخاصـة(؟)، لـذا ذهب أرسـطو إلى أن أفضل الحكومـات هـى الحكومـة الدستورية تلك التى يقوم دستورها على فكرة الجمـع بين العناصر الصالحة فى النظامين الايمقراطى والإستقراطى("). وتحقيقًا لذلك قام أرسطو بإدماج العديد من العناصر من ذلك(؛): أولاً: التوفيق بين مبدأ النظام الديمقراطى المتمثل فى المساواة السياسية، ومبدأ النظـام الأوليجـاركى المتمثل فـى تمييز طبقة محدده، بحيث تقتصر الحيـاة السياسية عليهـا، وذلك مـن خـلال إشـتراط مسالى بسيط يوحد علـى الكافـة للمشاركة فى الحياة السياسية. ثانيـاً: الجــع بـين وسـيلة القرعـة لإختيـار الدكـام التى تعكس مبـادئ النظـام الايمقراطى، ووسيلة الإختيار التى تعكس مبادئ النظام الأوليجاركى، بحيث يعين عـدد مـن الحكـام عـن طريـق الإنتخـاب والبعض الاخـر عـن طريـق القزعة. 
ومفاد ما سبق أن أرسطو رأى أن الحل الأمثل أو النظام الأفضل هو الذى يحقق التوازن بين كلا النظامين(')، هذا بالإضافة إلى "تأكيده سيادة القانون وجعل ذلك شرط صلاحية للنظام، ويرجع ذلك لاقتناعه أن الحاكم بشر يخطئ ويتأثر بالشهوات مثله في ذلك مثل باقي أفراد المجتمع، مهما يكن متمتعـا بالحكمـة والرزانـة والعقل، أمـا القانون فإن أحكامه موضوعية ومجردة تحقق العدالة أكثر من غيرها()"("). "واتساقا مع منهجه الواقعي انتهى أرسطو إلى أن الحكم الأمثل والأفضل هو ذلتك الذي يجمع بين عناصر الايمقراطية الصالحة وعناصر الأوليغارشية أيضاً(؛) المنتشرتان في عصرهـ حيث تعطى السلطة لطبقة وسطى لا هـي بـالفقيرة كمـا في الايمقراطية ولا هي بالغنية كما في الأوليغارشية، وتستمد مزايا هذا النظام من صفات الطبقة الوسطى التي أوضحها وعددها ، من عدم إسراف وعدم تهرب من المناصب بالإضافة لقلة إثارتهم للآخرين أو إثارة الآخرين لهم، وتمتع الكثير منهم بفن القيادة، كل هذا بعكس الطبقة الغنيـة التي لا تخضع لأي سلطة والطبقة الفقيرة المفتقرة لفن

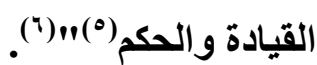

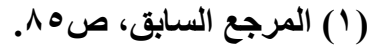

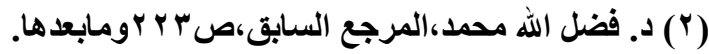
(ץ)

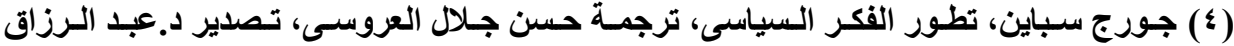

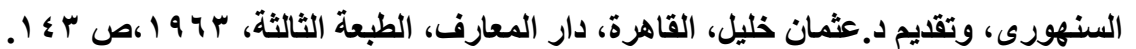

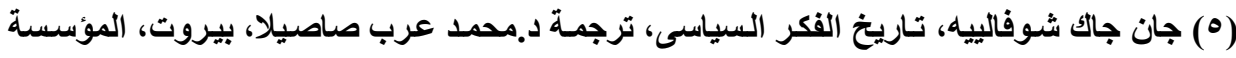

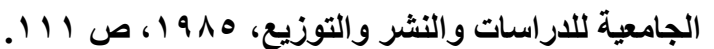

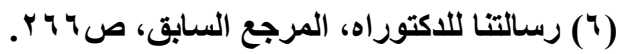


ويتضح من تقسيم أرسطو لسلطات الدولة، ووظيفة كل سلطة منها، أن أرسطو

سعى لعدم سبطرة فرد أو فئة على كافة سلطات الدولة، وتطبيقًا لذلك قسم هذه السلطة وجعل لكل سلطة وسيلة لمراقبة الأخرى.

"فقد قسم أرسطو الدولة إلى ثُلاث أقسام تتمثل في: السلطة التشريعية تختص بالبت في المسائل الهامة والحيويـة في الدولة وهي أهم السلطات وأولها وتتركز في جمعية المواطنين، السلطة التنفيذية وتتولى تنفيذ القوانين والسهر على حفظ الأمن، وتخضع في عملها للسلطة التشريعية، السلطة القضائية ومهمتها الفصل في المنازعات المختلفة، وهي هيئة مستقلة ذات سلطة حقيقيـة، لذا فهي تقوم بمراقبـة السلطتين

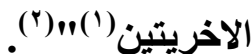

مفاد ماسبق أن تقسيم أرسطو لسلطات الدولة وإيجاد نوع من الرقابة المتبادلة، يأتى من خلال مبدأ سيادة القانون والسعى لتطبيقه، وذللك تأسيساً على فكرته أن النظام الأمثل هو الأى يقيم التوازن والتوافق بين عناصر مختلفه. ولهذا يمكن القول أن أرسطو عرف مبدأ الفصل بين السلطات، وذلك فى صورته المرنة، حيث وجدت علاقة بين سلطات الدولة المختلفة ورقابة متبادلة. 


\section{المبحث الثانى \\ لدى فلاسفة العقد الإجتماكى}

تتضمنت نظريـات العقد الإجتمـاعى العديد من الأفكار السياسية الحديثة، تلكك

الأفكار التى عدت أساساً للعديد من المبادئ، من ذلك مبدأ الفصل بين السلطات.

فقــ درج الفقهــاء علـى إرجــاع أســاس مبـــأ الفـصل بـين الـسلطات إلـى

نظريـة مونتسكيه وأفكـاره، وبـالرغم مسن إتفــاق الكافـة على ذلـك إلا أنهـم لـم ينكـروا

أن أفكار مونتسكيه وجدت بـذور لهـا لـدى لـوك، كمـا أن روسـو قد حدد موقفهـ مـن

المبدأ.

وبناءً على ذلك نتناول أفكار لوك وروسو، ومونتسكيه، وذلك فيما يلى:

المطلب الأول: لوك.

المطلب الثانى: بوسو.

المطلب الثالث مونتسكيه. 


\section{المطلب الأول}

\section{لوك}

أدت أفكار لوك عن حالة الطبيعة وإبرام العقد الاجتماعى إلى الوصول إلى تكوين نظام قانونى ألا وهو الدولة وذلك بخلاف المجتمع، وهذا ما عد أساساً لفكرة الفصل بين السلطات.

هذا بالإضـافة إلى تحديـ لـوك طبيعـة العلاقة بين سـلطات الدولـة، ولكن هـل

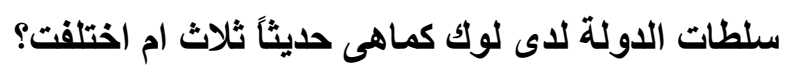
وبناءً على مـا سبق نتساول أسـاس المبدأ لدى لوك الذى تتضمنته أفكاره عن الاولة والمجتمع، ثم لسلطات الدولة والعلاقة فيما بينهم، وذلك فيما يلى: الفرع الأول: الدولة والمجتمع. الفرع الثانى: سلطات الدولة والعلاقة بينهم. 


\section{الفرع الأول \\ الدولة والمتهمع}

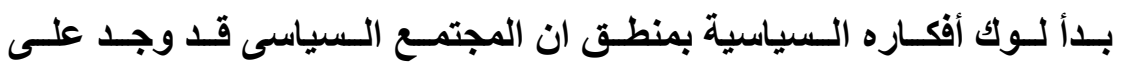

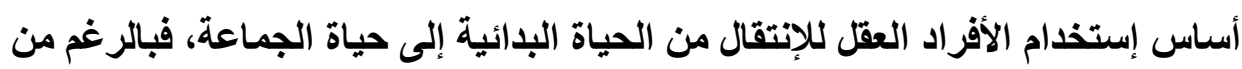

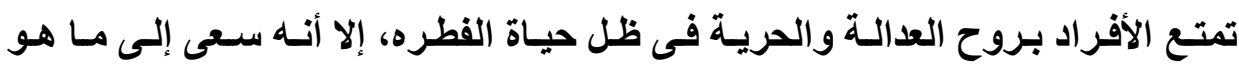

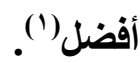

وتفصيل ذلك أنه رأى " أن حالة الطبيعة أو الفطرة الأولى هي حالة سلام وود وطمأنينة وأمان وتبادل مصالح وحسن نية(')

وقد تمتع الإنسان في حالة الطبيعة بحرية كاملة حيث يتصرف كل فرد كما يحلو

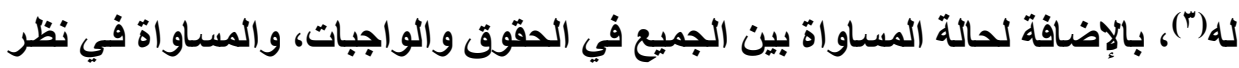

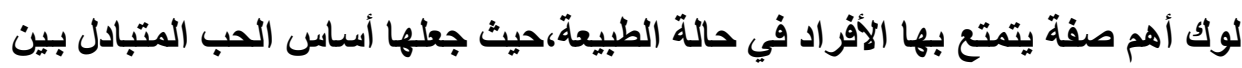

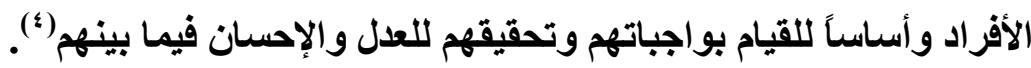

(1) د.فضل الله محمد إسماعيل، رواد الفكر السياسى الغربى الحديث، دار الجامعة الجديده، ^ . . r،

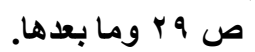

Locke:Essay concerning the true origin, Extene and end of civilGovernment, London, Allen \&unwin, 1960, p.68

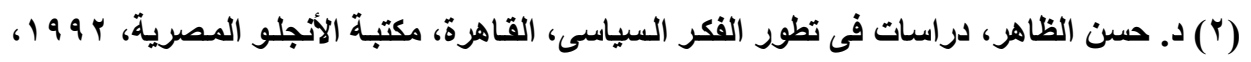

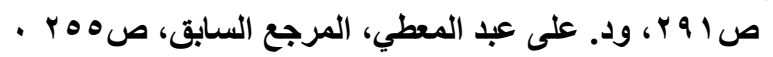

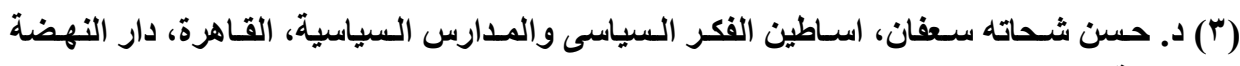

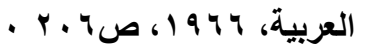

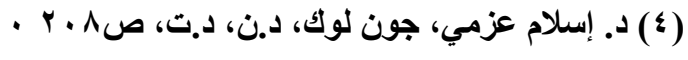

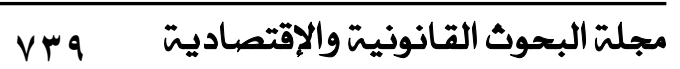


وبالرغم من هذه المميزات الممنوحة للأفراد إلا أن هذه المميزات تذور في إطـار محدد ومنظم،فمن ناحية الحريـة فبالرغم من إطلاقها إلا أنها مقيدة بقانون فطرى ألا وهو القـانون الطبيعي،فكل فرد مقيد بحدود هذا القـانون،ومن ناحيـة المساواة فهي مساواة أمسام القانون وليست مساواة في القدرات والإمكانـات المتاحة لكل فرد،وبنـاءً على ذلك يمكن القول أن حالة الطبيعة لدى لـوك هي حالة اجتماعية يسودها القانون

الطبيعي ولم تكن حالة حرب أو فوضى ولكنها ليست مدنية أى ليست مجتمعاً مدنياً' '. ويثار تساؤل في ظل المميزات التي يتمتع بها الفرد في حالـة الطبيعة من حريـة ومساواة، لمساذا يتـازل الأفراد عن هذه المميزات للـخول في المجتمـع السياسي أو المجتمـع المـدني؟ أجـاب لـوك عن ذلك مقرراً أن الأفراد سـعوا للـدخول في المجتمـع السياسي بـالرغم من المميزات المتاحة لهم لافتقار حالـة الطبيعة لثلاثة أمور هامـة يتزتب عليها عدم التمتع بالاستقرار والاستمرار في التمتع بهذه المميزات،وتتمثل هذه

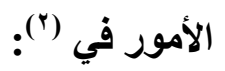

أولاً: عدم وجـود قـانون معروف ومستقر يحظى بقبـول الكافـة بوصفه المعيـار المحدد للصواب والخطأ، وذلك بـالرغم مـن وجود القـانون الطبيعي، وذلكك لغموضه بالإضافة لتحيز كل فرد لمصلحته الخاصسة فيسعى كل فرد لتفسيره بما يصب في مصلحته أو عدم الاعتراف بـه في النزاع الخـاص بـه إذا ثبت خطؤه.

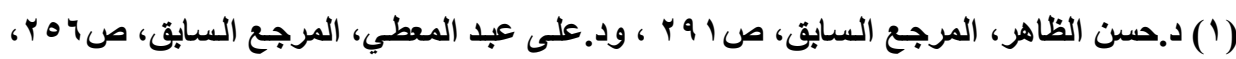

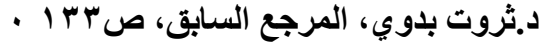

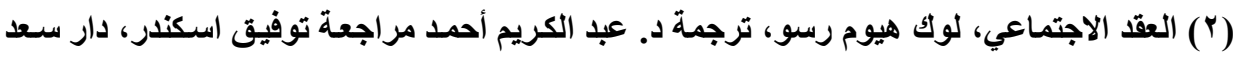

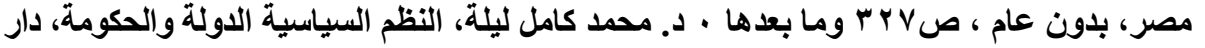

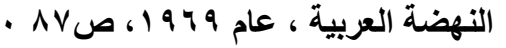


ثانيا: : عدم وجود قاض معروف غير متحيز للحكم في كافة النزاعات بنـاءً على القانون المعترف به، حيث إن كل فرد في حالة الطبيعة قاض لنفسه فيكون خصماً وحكمـاً في نفس الوقت وهـو مـا لا يجوز، لتحيز كل فرد لمـصلحته الخاصة.

ثالثا: عدم وجود القوة التي يمكن بها تنفيذ الحكم الصادر،ففي كثير من الأحيان

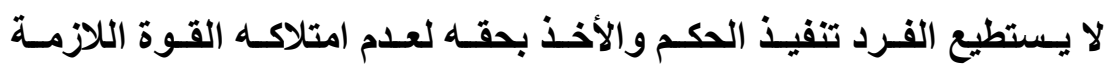
ل) لك.

وأمسام عدم وجود هذه الأمسور الهامـة يصبح تمتع الأفراد بالحريـة والمساواة والمحافظة على ملكيتهم الخاصـة في خطر محدق وتهديلـ مستمر، لذلك سعى الأفراد لإنشاء المجتمع السياسي واللـخول فيه، لضمان تمتعهم بمميزات الحريـة والمساواة بصفة دائمة ومستمرة ومستقرة. ولكن كيف يمكن تكوين مجتمع سياسـي؟ وجدت نظريتـان أساسيتان فى هذا الشأن خلال هذه الحقبة وهما'(') أولاً: أن الله مـنح السلطة لبعض الأشـخاص الذّين كونـوا الحكومسة الشرعية، ويترتب على ذلك تمتع الملوك بسلطات مطلقة بالإضـافة لتقرير مبدأ الوراثة وهو مـا دعا الملوك لتأيبدها. ثانياً: أن الدولـة تكونت نتيجة عقد أبرم بين جميع الأفراد وهذا شـأن دنيوي

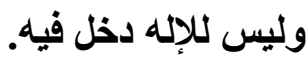

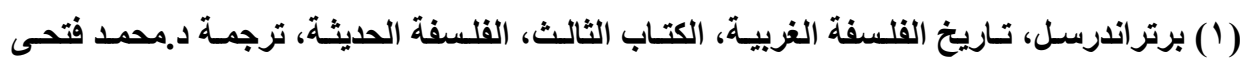

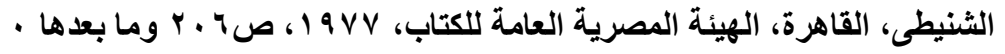


وقد اتبع لوك النظرية الثانية،حيث اقتنع أن المجتمع السياسي تكون نتيجة لعقد أبرم بين كافة|لأفراد من جهة والحاكم أو السلطة من جهة أخرى،وهو بذلك يخـالفهويز من حيث أطراف العقد،حيث إن الحسكم ليس أجنبياً عن العقد بل هو طرف فيه يلتزم بموجبه بالتزامات محددة تجاه الأفراد (')

وبموجب هذا العقد يتنازل الأفراد عن بعض حقوقهم وليس كلها وذلك للوصول لحياه أفضل ،حيث يتنازل الأفراد عن("): ا ـ حقوقهم في المحافظة على حياتهم في وجود السلطة، فطالمـا أن السلطة موجودة وتستطيع الدفاع عن حياتهم فلا داعي لتصرف الأفراد. r - حقهم في إنزال العقاب على الجاني،وتوجيه قوتهم لمساعدة السلطة التنفيذية في تنفيذ أو إنزال العقاب.

ولكن مـا يجب ملاحظتهـه أن الأفراد لا يتـــازلون عن هـذه الحقوق للملكت أو

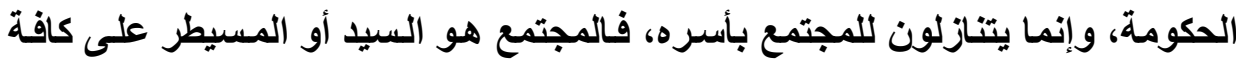
الأمور.وقد سعى لوك لجعل المجتمع بأسره هو المسيطر لإنهاء سيطرة الملوك والحد من سلطاتهم المطلقة التي كانت تؤدى للاستبداد و الطغيان(")، فالحساكم أصبح ملتزماً بتنفيذ القانون والمحافظة على الأفراد وحقوقهم من مال وملكية . 


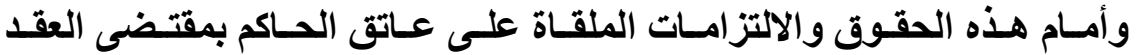

الاجتماعي، توصل لوك لعدة نقاط'(')

1 ـ أن الأغلبية هي أسـاس كل شـيء ومصدر كافة السلطات،ويجب على الأقلية الخضوع لها وإلا أصبح التوصل لقرار في منتهى الصعوبة، في ظل صعوبة

$$
\text { إجماع الكافة على رأى واحد)" }
$$

r ـ التزام الحاكم بالقانون في ممارسته لوظائفه واستخدامه لسلطاته.

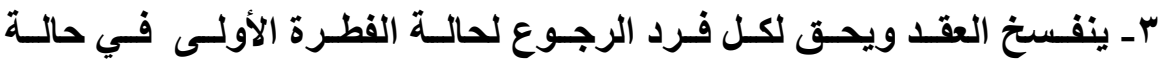
إخلال الحاكم بشروط التعاقد،بعدم تنفيذه لواجباته الملقاة على عاتقـه بموجب

والخلاصـة أن لوك جعل السيادة والسلطة في يــ الجماعة وليس في شخص

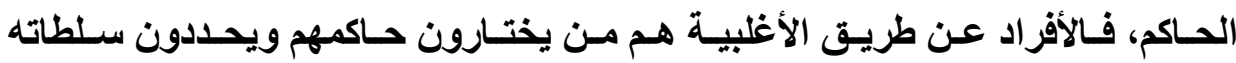
ويسألونه عن واجباته فهم مصدر كافة السلطات في الاولة"("). ويرى لوك أنه بإنتقال الجماعة من حالة الفطرة إلى المجتمع المدنى بإبرام العقد الإجتمـاعى، يتـولى أفراد أمـور الحكم وهذا مـا يعرف بالحكومـة، والحكومـة تختص بتحقيق الامـن والسلام، بجانب سـيها لتحقيق غايـات المجتمع المختلفة، مـن حمايـة حقوق الأفراد، وحماية المجتمع من أى عدوان خارجى(؛). (1) د. فضل الله محمد، المرجيع السابق، صه و و ومــا بعدها ؛ و د.فؤاد العطار، المرجيع السابق،

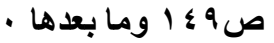

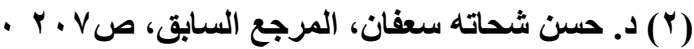

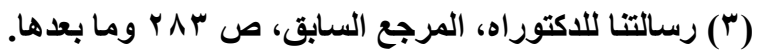
(؛) د.فضل الله إسماعيل، رواد الفكر السياسى الغربى الحديث، المرجع السابق، صسآوما بعدها. 
وتجدر الإشارة هنا إلى أن لوك ميز بين المجتمع والحكومة، فـالمجتمع لايسه هو الأهم والأعلى دائماً، أما الحكومة فهى خادمة لتحقيق رغبات المجتمع، لذا فِإن إنحلال

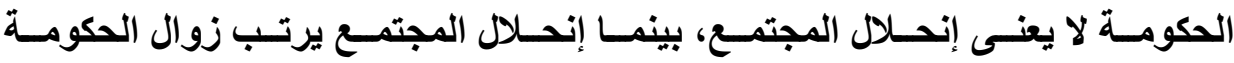

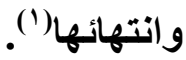

وتطبيقاً لـلـلك يـتم اختيـار الحكومـة مـن قبـل أفراد المجتمـع، ويكفى حصول

الحكومة على الأغلبية لمباشرة مهامها، فالشعب هو صساحب الكلمـة العليا، وإن كانت

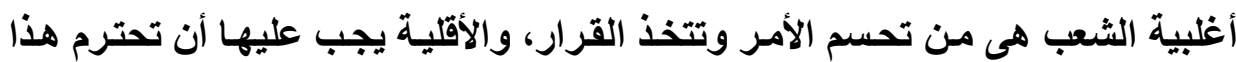

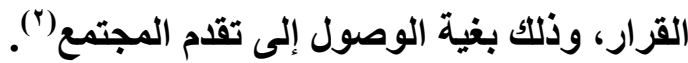

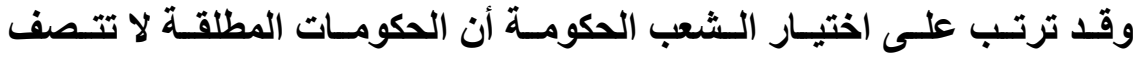

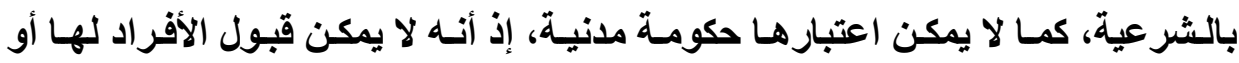

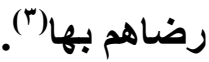
ومما سبق يمكن القول أن الفرد فى حياة الفطره للدى لوك كـان يمتلك حق او سلطة إتخاذ الإجراءات التى يراها كفيلة بالمحافظة على نفسه، هذا بالإضـافة لسلطته فى توقيع الجزاء على كل من يخالف الأوضاع الثابته(؛).

(1) د.فضل الله إسماعيل، المرجع السابق، صبr.

Karminck Isaac "Editor": Essays in the history of political thought, New jersey prentice hall Englewood clifs, 1969, p.221.

(ץ) شوفالييه، المؤلفات السياسية الكبرى من مكيافيللى إلى أيامنا، ترجمة إلياس مرقص، بيروت دار

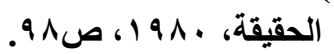

W.T.jones: Masters political though, boston, houghter Mifflin, 1941, p. 174.

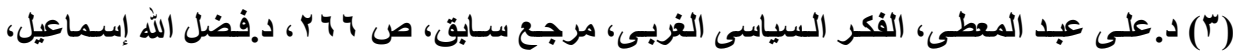

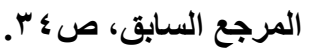

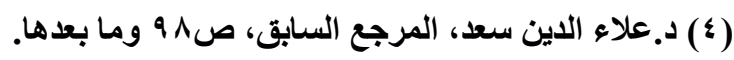

V 
إلا أن الفرد ويابرامه العقد الإجتماعى قد تنازل عن هـاتين السلطتين للجماعة،

فالفرد قد تنازل عن حقه فى تنفيذ القانون، وعن حقه فى توقيع الجزاء على من يخالف القانون، وهو فى ذلك يسعى أن يزيل فكرة السيادة المطلقة ويمنح المجتمع أو الشعب

الكلمة العليا'(')

وتأكياً لرفضه الحكم المطلق أشترط لوك فى كل نظام صحيح أن يؤسس على مبدأ الفصل بين السلطات، وذلك الرأى لايسه مرجعه إلى تـأثره بـالخلاف الدائر فى عصره بين الملوك من جهة والبرلمان من جهة أخر(؟). ويمكن القول أن لوك أسس إعتناقه لمبدأ الفصل بين السلطات على عدة أمور،

$$
\text { تمثثت فى (") }
$$

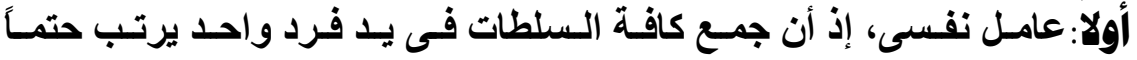
الإسـتبداد، حيـ أن الفـرد بطبيعته يميل إلى المفـالاه فـ إستعمال سـلطته وإســاءة استعمالها، لذا وجب وضع قيود صارمه عليه للحد من طبيعته هذه، وهذه القيود تتمثل

(1) د.فؤاد العطار، النظم السياسية والقـانون الاستورى، المرجع السابق، ص هـ 1 ، د.فضل الله

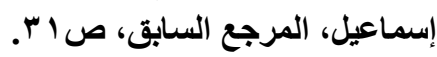

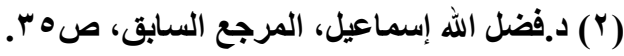

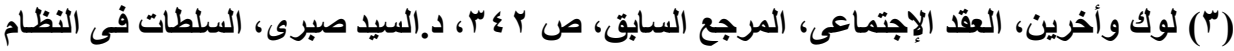

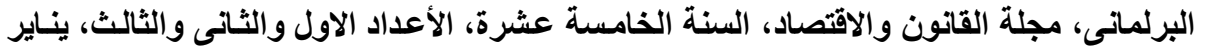

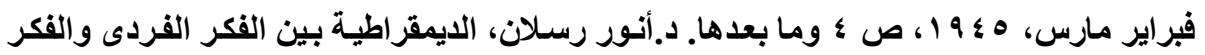

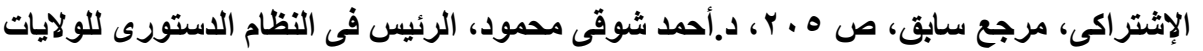

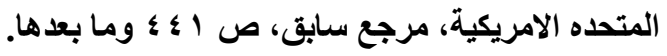

Esmein(A): Elements de droit constitutionnelFrancais et compare, tom 1, paris, 1927, p. 494 et. $S$ 
فى توزيـع السلطات على عدد مـن الأفراد أو الهيئـات حتى يمكن لكل سـلطة إيقـاف (الاخرى (').

ثانيساً: عامل عملى: يتمثل فى أن سلطة التشريع تختص بسن القوانين التى تتسم بالعمومية والتجريـد، وذلك بغيـة الوصول إلى تطبيقها على الكافة دون تمييز، وهذه القوانين تطلب تنفيذاً ومراقبة مستمره لكيفية التنفيذ. لذا ولتهيئة السلطة التشريعية لإعداد القوانين بعنايـة ودقة، وذلك فى سبيل تحقيق الصالح العـام، وجب فصل هذه السلطة عن السلطة التففيذية التى تعدل على تنفيذ القوانين بصورة دائمة.

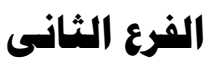

\section{سلطات الدولة والعلاقة بينها}

ترتـب على تحسـول الأفـراد مـن حالــة الفطـرة إلـى حالــة المجتمــع المــنى

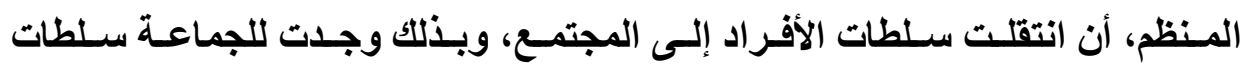

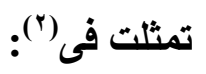

(1)William Ebnestien: Great political Thinkers from plato to the present, Illinis, Dryden, press, 1969. P.409

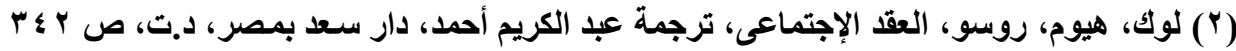

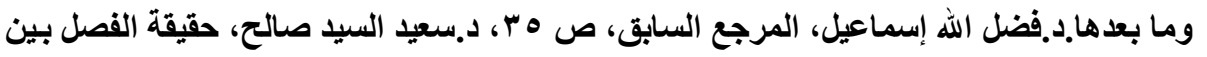

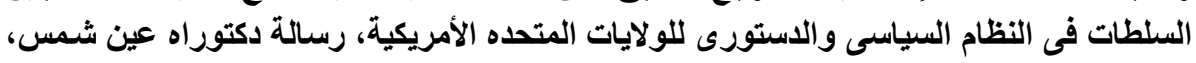

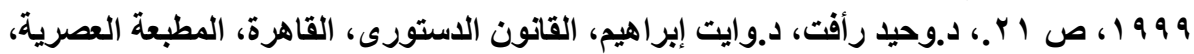


أولاًا:الساطة التسشريعية: وهى تختص بوضـع القواعد اللازمـة لحفظ الجماعـة وتحقيق الصالح العام، وهى تتشكل من ممثلين للشعب والملك. وهذه السلطة حلت محل سلطة الفرد فى إتخاذ الإجراءات الكفيله لحماية نفسه فى حالة الفطرة. ثانياً:السلسطة التنفيذيـة: وهى تختص بتنفيذ القوانين الوضعية فى الداخل، والملك هو من يهيمن على هذه السلطة، فوفقاً للوك أن من يضع القوانين لا يجب أن يقوم بتنفيذها. وهذه السلطة حلت محل سلطة الفرد فى توقيع الجزاء على كل من انتهك قوانين الطبيعة، وذلك فى حالة الفطرة(') ثالثـاً:الـسلطة التعاهديــة أو الفيدراليسـة: فبجانسب السلطتين التشريعية والتنفيذية، أوجد لوك سلطة أخرى تختص بالمسائل الخارجية كعقد الإتفاقات، وإعلان الحرب، وتقرير السلام، وهى السلطة التعاهدية(؟) وتجدر الإشارة إلى أن لوك لم يعتبر السلطة القضائية سلطة قائمسة بذاتها، وإن ألحقها بالسلطة التشريعية(")، ويرجع ذلك إلى تأثر لوك بالدستور الإنجليزى الذى سمح

(1) د. محمد بكر حسين، النظم السياسية "الدولة والحكومة، القاهرة، مكتبة السعادة، 19191، ص .19

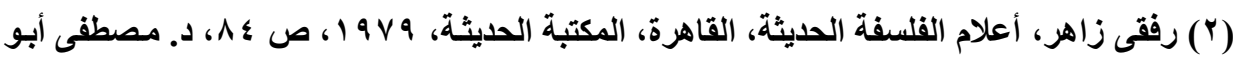

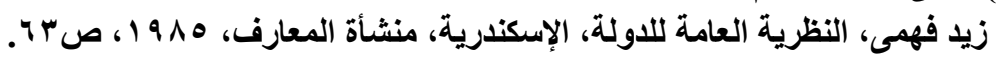

A.C. Kapaor: Principles of political scierce, New delhi press, 1987, p. 378. (3)Sir Ivor Jennings: The law and The constitution, London, fifth edition, E.L.B.S, 1979, p. 19 -20. 
بإندماج السلطة القضائية بالتشريعية، وذلك مـن خـلال إحتفـاط البرلمـان بالعديـ مـن

(') الإختصاصات القضائية)

هذا بالإضافة إلى أن القضاه قبل ثورة ^^^ 1 1، كانوا خاضعين لسلطات الملك من حيث التعيين والعزل وتلقى الأوامر، أى أنهم كانوا تابعين تابعيه تامـة للملك، وهذا

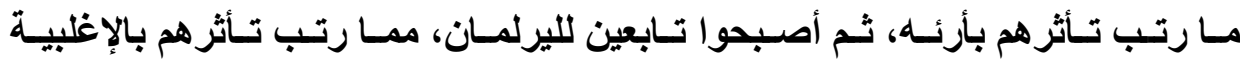

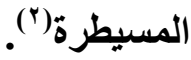

وبالرغم من تقسيم لوك للسلطات إلى ثلاث إلى أنه ذهب إلى أن مبأ الفصل بين السلطات يقتصر على السلطتين التشريعية والتنفيذية، حيث لا يجب تركزيهمـا فى يـ واحـده، بـل يجـب أن يتولهمـا هيئسات مختلفـة، فالسلطة التشريعية تخـتص بإصــار القوانين، فإذا ما أجتمعت معها السلطة التنفيذيـة أمكن إصدار قوانين تثفق مـع أهواء

بيد أن السلطة الاتحاديـة يجب أن تجمـع مـع السلطة التنفيذيـة فى يـ واحده، ويرجع ذلك بسبب إعتمادهما على استخدام القوة المادية للاولة، لذا لا يحبذ أن تتفرق القوة المادية للاولة على عدة هيئات، إذ أن تفرقهما قد يؤدى إلى الفوضى والدمار (؛).

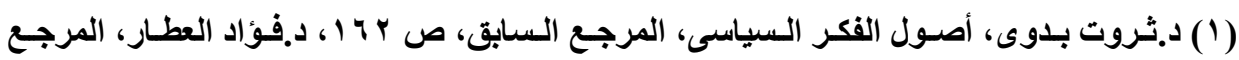

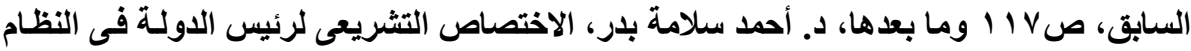

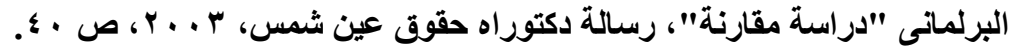

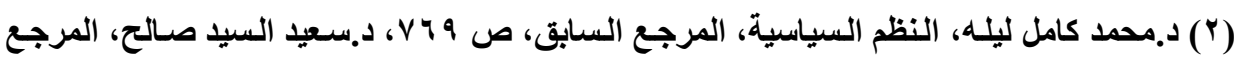

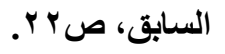
(r) أدمون ربـاط، الوسيط فى القانون الدستورى العام، الجزء الثانى، بيزوت، دار العلم للملايين،

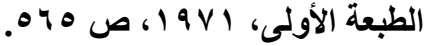
( ) لوك وأخرين، المرجع السابق، ص ؟ ؛ ؟ب، د.العيد صبرى، السلطات فى النظام البرلمانى، المرجع

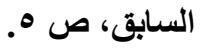


وفى إطار العلاقة بين السلطات، ذهب لوك إلى أن السلطة التشريعية يجب أن تكون هـ الأعلى و تحتل مكان الصداره، فقد أعطى لوك السلطة التشريعية قدسيه خاصه، بحيث تهيمن على السلطة التنفيذية وخضعت لهاب('). وبالرغم من جعله السلطة التثريعية الأعلى إلا أن سلطاتها ليست مطلقة، وإنمـا

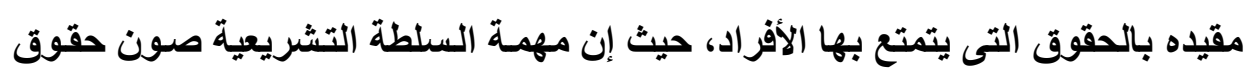

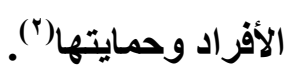

وتطبيقاً لذلك وضع العديد من المبادئ التى يجب على السلطة التشريعية الإلتزام

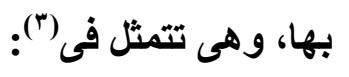
أولاً: أن سن القوانين يجب أن يهدف للصالح العام دون تعسف. ثانياً: إن القوانين يجب أن تطبق على الكافة وعلى قدم المساواة دون تمييز. ثالثاً: أنه لا يمكن فرض ضر ائب دون موافقة الشعب. رابعاً: أنه لا يحق التنازل عن حق التشريع لأى جهة أخرى، إذ أنها هى السلطة المنوطه بذلك.

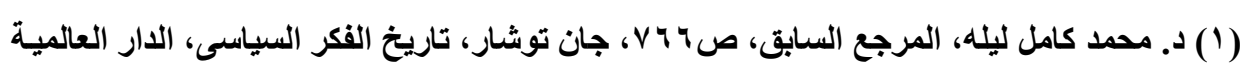

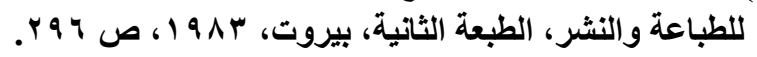

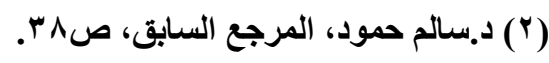
S.Plamkrechf: The Moral and political philosophy of J.locke, Newyork, the macmillan ca, 1961, p. 65.

(3) Locke: civil, op. cit, p. 151. 
إلا أن السؤال يثُور حـل كيفيـة تحقيـق الفصل بـين السلطتين التشريعية و

التنفيذية فى ظل خضوع الثانية للاولى وفقاً لأفكار لوك؟

وقد وجدت الإجابة لدى لولك ذاته حيث ذهب فى تبرير الفصل أن تشكيل السلطة التشريعية يتضمن ممثلي الثعب بالإضافة للملك، ومن ثم لا يمكن أن يصدر أى تثريع

إلا بموافقة الملك ممثل السلطة التنفيذية، وهذا ما يحقق التوازن بين السلطتين('). إلا أن هذا التبريـر مـن قبـل لـوك جعل البعض يـذهب إلى أن أشـراك السلطة التنفيذيـة مـع السلطة التشريعية فى إصـار التشريعات، بجانب قيامها بمهامها يعد إدماجاً للسلطات، مما يخالف مبأ الفصل بين السلطات، إلا أن لوك ذهب لمخالفة ذلك، موضحاً أن ذلك لا يعد دمجاً حيث أن الملك لا يمثل إلا جزءاً من السلطة التشريعية، فالقوانين لا تصدر بإرادته المنفرده أو حتى تتوقف عليه، بل أن ممثلى الشعب لابد أن

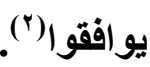
ويمكن القول ان لوك أسس أفكاره حول الفصل بين السلطات تحت تأثير النظام الإنجليزى الأى عاصره، لذا نجده يوضح أن الفصل يتمثل فى إيجاد نوع من التعاون والتوازن بين السلطات، إلا أن الملك يقوم بلور أساسى فى ظله.

حيـث يعتـرف للملــك بالعديـــ مـن السلطات مـن الإنفـراد بالسلطة التنفيذيـة والإتحادية، والمشاركة فى إصدار التشريعات مع السلطة التشريعية(")

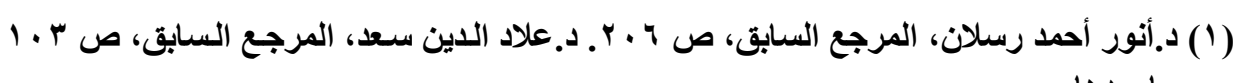

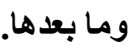

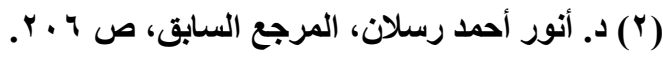

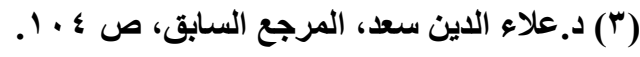
VO. مجلة البحوث القانونيت والإقتصاديت 
كما أن لوك قد قصر الفصل بين السلطات على السلطتين التشريعية والتنفيذية مستبعداً السلطة القضائية، وذلك تحت تأثره بوضع السلطة القضائية فى عصره فى ظل النظام الإنجليزى، حيث أتسمت بتبعيتها إما للملك و إما للبرلمان. وقد مثل هذا الامر عيباً خطيراً وتناقضاً فى نظريـة لوك، فهو من ناحية يجعل القانون أداة لحماية مصلحة الأفراد و حقوقهم، فهو دعى لسيادة القانون، إلا أنه ومن جهة أخرى لم يؤكد على إستقلال القضاء بالرغم من أن القضاء هو الجهة الوحيده القادره على ضمان سيادة القانون(') وإن كان موقفه مبرراً فى ظل تأثُره بالنظام الإنجليزى، إلا أن هذا العيب يظهر فى المجتمعات الأخرى التى لا تثبه النظام الإنجليزى، من حيث تأثر السلطة القضائية

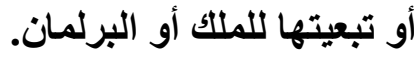

ومفـاد مسا سبق أن لوك عرف مبدأ الفصل بين السلطات، وإن كـان بصوره منقوصـه، كمـا أوجد علاقة بين السلطتين التشريعية والتفيذيـة، بحيث أمكن القول بوجود تعاون وتوازن بينهما.

(1) د. أنور أحمد رسلان، المرجع السابق، ص V • ץ. د.العيد صبرى، السلطات فى النظام البرلمانى،

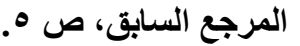
Locke, Hume, Rousseau: Social contract, London, oxford university press, 1948, p. 338.

VO مجلت البحوث القانونيت والإقتصاديت 


\section{الاملب الثانى \\ روسو وهبدأ الفصل بين السلطات}

يعد روسـو من أبرز الفلاسفة الذين سـاهموا فى الدعوات التحرريـة، وإرسـاء

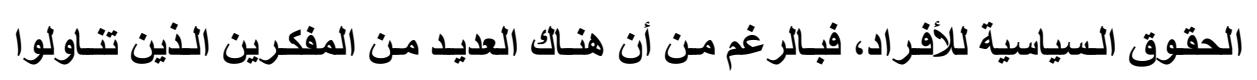

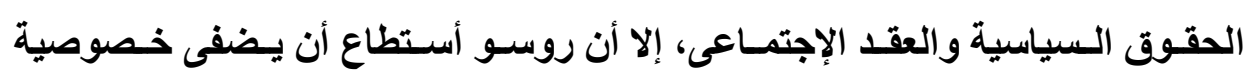
لأفكاره، وذلك فيما يتعلق بالحرية والمساو الة'(')

وبالرغم من إتجاه روسو إلى تقليس حقوق الفرد السياسية والحرية والمساواة

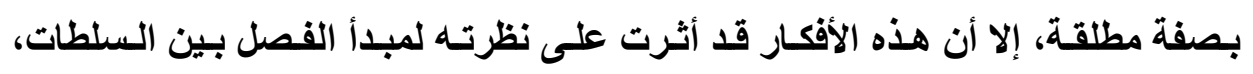

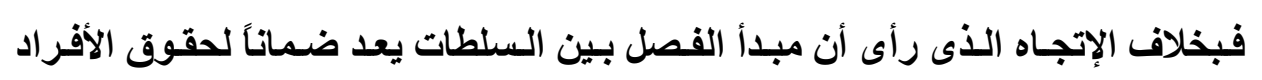
و حريتهم، رأى روسو عكس ذلك نتيجة لنظريته عن الإرادة العامة والسيادة. وبناءً على ذلك نتناول نظرية السيادة لاى روسو، وذلك لتبيان موقفه من مبدأ الفصل بين السلطات، وذلك فيما يلى:

الفرع الأول:نظرية روسو عن السيادة.

الفرع الثانى: روسو و الفصل بين السلطات.

(1) (1) د. فضل الله إسماعيل، المرجع السابق.

Vor مجلة البحوث القانونيت والإقتصادية 


\section{الفرع الأول}

\section{نظرية روسو عن السيادة}

بأ روسو نظريته عن السيادة بتعريفه الإرادة العامة وكيفية تكوينها، فقد ذهب إلى أن المجتمع السياسى شخصية معنويـة ذات إرادة هى الإرادة العامـة، هذه الإرادة تتحو دائماً نحو تحقيق وصيانة الرفاهية للمجتمع،"وهى مصدر القوانين وتتكون من كل الأفراد فى علاقتهم بالدولة وفى علاقاتهم بعضهم ببعض وحكمها دائمساً عـادل غير

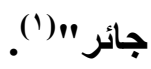

ويتضح من ذلك أن الإرادة العامة تمثل إرادة كافة المواطنين حينمسا يسعون إلى

تحقيق الصالح العام وليس الصالح الثخصى، فـالإرادة العامـة يقصد بها صوت الكل لصالح الكل، وفى ذلك يرى روسو أن إرادة الفرد التى تسعى إلى الصالح العام أفضل من إرادته التى تسعى إلى الصالح الخاص أو الثخصى (؟).

وفى سبيل ذلك فرق روسو بين نوعين من الإرادة، أولاهمـا الإرادة العامـة التى تمثل علاقة الجماعة بكافة أعضاء المجتمع، وثانيهما الإرادة الخاصة التى تمثل علاقة الجماعة بأعضائها هى فقط.

وحسب ذلك أن كل مجتمع سياسـى يتضمن العديد من الجماعـات الصغيرة ذات الإهتمامات المختلفة، كما تطبق كلا منها قواعد خاصة لضبط سلوك أعضائها، فبإذا مـا قامت الجماعة بالتعامل مـع أعضاء كافة الجماعات الذين يمثلون المجتمع وجدت مـا

$$
\text { (1) د.فضل الله إسماعيل، المرجع السابق، ص ^^وما بعدها. }
$$

(2) W,Ebenstien: Great political thinkers, op .cit, p.438 
يسمى بـالإرادة العامـة، أمسا إذا أقتصر تعامل الجماعة مـع أعضائها وجدت مـا يسمى

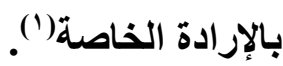

ومما سبق يمكن القول أن الإرادة العامة هى الوسيلة التى من خلالها يستطيع

الإنسان التعبير عن حريته كعضو من أعضاء المجتمع، فهى تعبير عن حرية الدولة التى قامت فى الأسساس من أجل صون حريات الأفراد(؟). فـالإرادة العامـة تمثل إرادة المجتمـع بأسره، وهـى تتصف بنزعتهـا المستقلة، والفرد يشارك فيها بإرادتهه من خلال المشاركة فى كافة القرارات التى تتخذ من قبل المجتمع إذ انه عضو من أعضائه، وقد ذهب روسو إلى أن هذه الإرادة "إرادة المجتمع

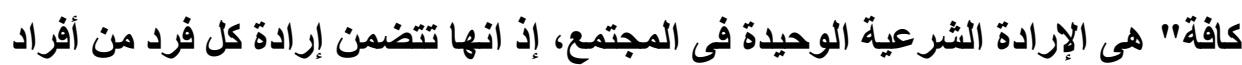
المجتمع، كما أنها تمثل إرادة كافة أفراد المجتمع(")

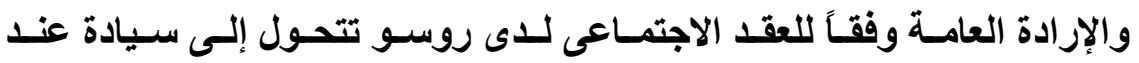
التطبيق، فبمقتضى العقد الاجتماعى ينشأ شخص عام تكون لـه السيادة، فالسيادة تعبر

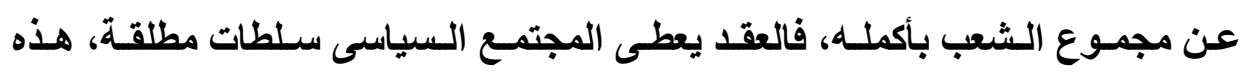
السلطات هى ما تتولاها الإرادة العامة "إرادة مجموع أفراد الثعب" وتسمى بالسيادة، لذا يمكن القول أن السيادة ليست إلا ممارسة الإرادة العامة(؛). (1 ) د.فضل الله إسماعيل، المرجع السابق، ص 99. (2)Rousseau: Social contract, oxford university press, 1948, p.xxx111-xxxv. (3)G.D.H.cole, Essays in the social theory, London old banrne science library, 1962, p.116-117.

$$
\text { (؛) ) د.فضل الله إسماعيل، المرجع السابق، ص V V وما بعدها. }
$$


ويرى روسو أن أساس السيادة لا يكمن فى القوة، إذ أن التسليم بذلك يتضمن إنكاراً لفكرة الحق كلية(')، كما أنها لا تجد أساسها فى فكرة السلطة الطبيعية التى للأب على أبنائه، وذلك لأن نظام الأسرة وإن كـان أقدم التظيمـات إلا أنسه ليس ظـاهرة غير إرادية، وإنما ظاهرة إرادية اتفاقية، ويرجع ذلك إلى أن الأطفال يرتبطون بأبائهم لفترة محدوده، وهى تلكك الفترة الذين يحتاجون فيها إلى الحماية والرعاية، ولكن بزوال هذه الأسباب تزول الرابطة الطبيعية بين الأبناء والأبـاء، ومن ثم يعد الأبن تابعاً لأبيه بعد ذلكك نتيجة اتفاق ورغبة منه فى البقاء داخل الأسرة(). ولكن ما هو أسـاس السيادة فى نظر روسو إذاً؟ يتمثل الأسـاس لايسه فى الشعب كافة، فالشعب يعد السيد المطلق للحقوق والسلطات، وكل فرد يعد عبداً لهذا المجموع "الثعب"، الذى يتسلط بقو انينه المعبره عن الإرادة العامة على الفرد، ومن ثم لله أن يفـرض مـا يـشاء مـن قيـود، ولا معقب ولا معدل على السيد لأنسه يعبر عـن الإرادة

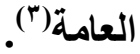

ومفاد ما سبق أن السيادة بموجب نظرية روسو قد خولت للشعب فى مجموعه، بحيث أصبح هو السيد فى دولـة لا تعرف الإستبداد أو الطغيان، هذا الشعب يمسارس سلطانه بواسطة القانون الذى يعكس إرادة مجموع الأفراد، وبناءً على ذلك ذهب روسو

(1) Rousseau: Contract social, op. cit, p.186.

(2) I bid, p.190.

(r) د.طه بدوى، أصول علم السياسة،الإسكندرية، المكتب المصرى الحديث، الطبعة الثانية، هبو اص 
إلى أنه ليس من المتصور أن يحدث جوراً، حيث انه من غير المعقول أن يقع من الفرد

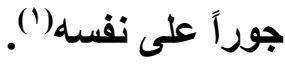

ومما سبق يمكن القول أن روسو قد مزج بين مفهومى السيادة والإرادة العامـة،

بحيث جطهما مفهومان لا ينفصلان، كما أنه وازن بين حقوق المجتمع المثثل للإرادة العامة وحقوق الفرد، فالفرد من جهة عضو فى الإرادة العامـة ومن ثم لهه نصيباً فى السيادة، كما ان المجتمع السياسى يقوم بتنظيم حرية الفرد ومساو اته بالأخرين، فكل عمل من أعمال السيادة يلزم كافة المواطنين على قدم المساواة(') وقد ترتب على أفكار روسو عن السيادة والإرادة العامة أن أكتسبت السيادة لديه سمات أثرت على فكرة الفصل بين السلطات، ومن أهم هذه السمات:

أولاً:السيادة غير قابله للتصرف فيها:

فروسـو يرى أن صـاحب السيادة ألاو وهو الشعب لا يمكنـهـ أن ينقلها إلى أى شخص أخر، وذلك على أساس أن السيادة تعكس حقيقة إرادة الثعب، والإرادة لا يمكن فصلها عن الإنسان، فالفرد لا يمكنه أن يتصرف فى إرادته، وذلك بخلاف السلطة التى التى يمكن أن تنتقل من هيئة إلى أخرى(")

وبنـاءً على ذلكك رفض روسو فكرة التمثيل النيابى، إذ رأى أن الإرادة أمـا أن تعلن عن نفسها أو تكون إرادة أخرى، ويرجع ذلك إلى أن روسو رأى أن فكرة وجود

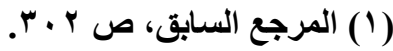

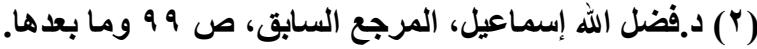

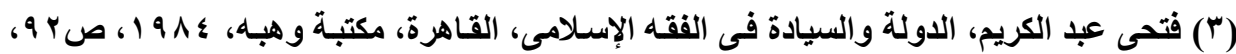

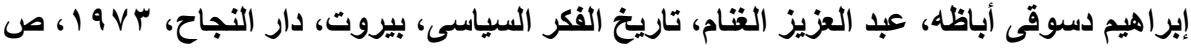


ممثلين للشعب فكرة تتسم بالحداثة نتيجة الحكم الاقطاعى الظـالم الذى أتصف بإهانته الجنس البشرى، لـلكت فنواب الشعب لـم بعدوا ممثلين وإنمـا مفوضسين، حيث أنهـ لايمكنهم إبرام شيئًا بصفة نهائية، فمثلاً القانون الذى لم يصادق عليه الشعب شخصياً

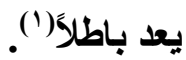

\section{ثانياً: السيادة لاتقبل التجرئة:}

ذهب روسـو إلى ان السيادة واحده، فـالإقليم لايمكن ان يتضمن سيادتين أى

سلطتين عليتين، فالإقليم يتضمن سلطة عليا واحده، أى سيادة واحده، ويرجع ذلك إلى

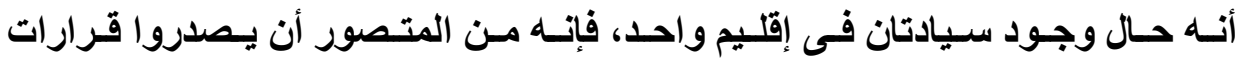
متضاربه، فهنـا إمـا ألا تتفذ هذه القرارات و إمسا أن ينفذ أمر واحد منها، وهنـا تكون السيادة لصاحب هذا الأمر فقط)"

وإرتباطاً بذلك لا يمكن للسيادة أن تقسم، إذ لا يمكن تفتيت السيادة إلى أجزاء

مختلفة توزع على هيئات أو أفراد مختلفة، ويكمن سبب ذلك أن السيادة إرادة والإرادة إمـا أن تكون كامله أو لا تكون نهائياً، فلا يتصور وجود إرادة جزئية أو ناقصه هذا من جانب.

(1) جان جاك شوفالييه، تاريخ الفكر السياسى، مرجع سابق، ص 9 و ؛ ـ د.فضل الله إسماعيل، المرجع

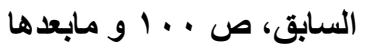

Rousseau: contract social, op.cit, p.207-294.

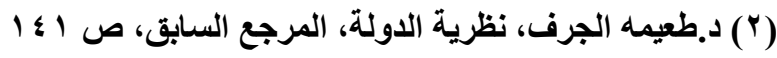

Duguet: Lecons de droit public General, paris, press universitairs de france, 1976, p.116. 
ومن جانب أخر فإن إفتراض التقسيم يعنى أن كل عضو تم التقسيم عليهه يعد

صاحب سيادة، وهذا ما لايمكن تصوره فى ظل وحده السيادة(').

إذاً فروسو يذهب إلى أن الإرادة العامة التى تعكس مجموع إرادة أفراد الشعب

هى أساس السلطات، هذه الإرادة تتحول لادى الممارسـة إلى سيادة، ومن فِان السيادة بإعتبارها إنعكاساً للإِرادة العامة فهى تخول للشعب، وهذا ما يستتبع القول بأن السيادة لا تقبل التنازل وإنها واحده، ولا تقبل الإنقسام.

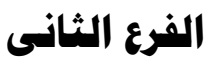

\section{روسو والفصل بين السلطات}

أثرت أفكار روسو عن السيادة والإرادة العامة على موقفه من مبدأ الفصل بين

السلطات، لما تتميز به السيادة من عدم التجزئة وعدم التصرف فيها، وقد لجـأ الساسة

فى سبيل التحايل إلى تجزئتها من حيث الموضوع إلى قوة وإرادة، وسـلطة تشريعية وسلطة تنفيذيـة، وإلى جاتب ذلك وجدت حقوق الضرائب والقضاء والحرب، وإرادة خارجية وأخرى داخلية، فقد جزئوا السيادة إلى جزئيات صغيره(`).

إلا أن روسو راى أن هذا الأمر يعد خطأ، ويرجع هذا الخطأ إلى عدم إنضباط الأفكار لاى السلطة السياسية، بحيث ان الساسة راوا أن هذه الامور تعد أجزاعاً من

(1) Duguet: Lecons de droit public General, op. cit, p. 117.

Duguit: Siverainiteetliberte, parissirey 1922, p.48et s.

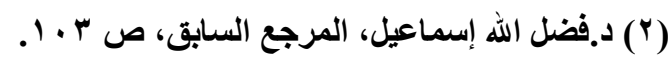

W.Ebenstien: Great political Thinkers, op. cit, p.448 el.s

F.W.coker: Reading in political philosophy, U.S.A, macmillan co, 1959, p.643. 
السلطة، فمثلاً هم يعتبروا أن سلطة إعلان الحرب وعقد السلام أجزاء من السيادة، فى حين أن هذه الامور ليست كذلك، فهى لا تعد قانونـاً وإنمـا هى تطبيق للقانون، لذا فلا تمثل السيادة فى شىع (') وتطبيقًا لنظريـة روسـو حول السيادة وعدم تجزئتها، فإنـه فرق بيلن السيادة والحكومة، إذ ان الأولى تخول للشعب وهى لا تتنقل إلى أخر، بينما الثانية وكيل مؤقت عن الشعب، بحيث يحق لهذا الاخير ممارسة كافة سلطاته عليها. ووفقاً لـه فبإن كل فعل يدفعه سببان لتنفيذه، أولاهمـا معنوى يتمثل فى الإرادة التى تحدد الفعل، وثثاتيهمـا مـادى يتمثل فى القوة التى تنفذه، والاولى تـدعى السلطة التشريعية والثانية تلدعى السلطة التنفيذية(؟). وقد رأى روسو ضرورة فصل السلطة التشريعية عن التنفيذية، وذلك لإختلاف طبيعة كلا منهما، فالسلطة التشريعية تكون من حق الشعب فقط إذ انها تمثل السيادة، لذا لا تمـارس إلا من خلاله، وهى تختص بوضع الاستور وسن التشريعات، كمـا لها

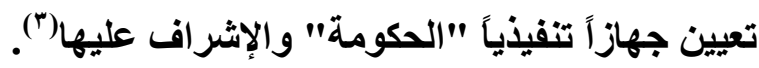
أمسا السلطة التففيذيـة فتقتصر مهمتهـا على تنفيذ القوانين والإشـراف على

تطبيقها (؛)

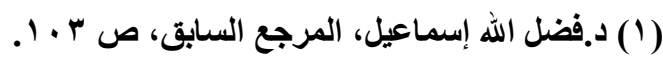

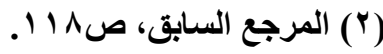

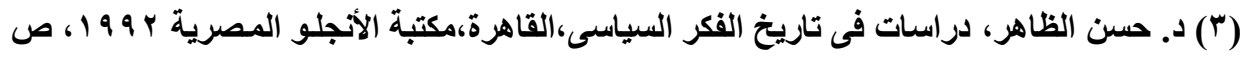
r

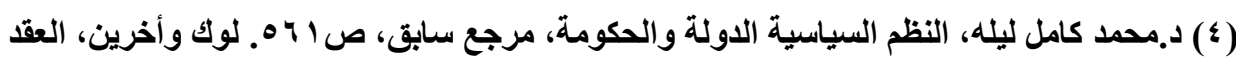

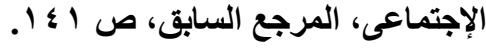


ومفـاد مـا سبت أن روسو فصل ببين السلطتين التشريعية والتنفيذية لإختلاف طبيعة كلا منهما، بالإضافة إلى أن عمل السلطة التشريعية يقتصر على سن التشريعات، وهذه العملية لا تستغرق وقتاً طويلاً، ومن ثم لزم وجود هيئة أخرى تقوم بتنفيذ هذه التشريعات، كمـا أنـه مـن المستحسن أن تتـولى هيئة خاصـة تنفيـذ التشريعات، إذ أن الشعب لا يمكنه القيام بهذه المهمة بنفسه، إلا أن السلطة التنفيذية تخضع فى ممارسـة أعمالها لإرادة الشعب ممثل السلطة التشريعية(') وبجانب هاتان السلطتان أوجد روسو السلطة القضائية ورأى ضرورة تمييزهـا عن السلطة التنفيذيـة، بحيث يجب مباشرتها من قبل هيئة متميزه، إذ أن الشعب فى مجموعه لا يمكنه ممارسة هذه المهمة بنفسه، مـع الاخذ فى الإعتبـار أن هذه السلطة تخضع فـى مباشـرتها لأعمـال السلطة التشريعية، لذا أجـاز روسـو التظلم مـن أحكـام

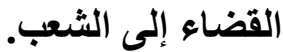
ومفـاد مـا سـبق أنـه بـالرغم مـن تمييز روسـو بين السلطات الثثلاث التشريعية والتفيذية والقضائية، إلا أن ذلك لم يعن عنده مبدأ الفصل بين السلطات، ويرجع ذلك إلى أن السلطة التففيذية وكذلك القضائية لا تملك أى جزء من السيادة، فالسيادة لديه لا تقبـل التجزئسة، لذا لا أحد يمتلكهـا أو يمثلهـا إلا السلطة التشريعية، ووفقـاً لـلتك فِان

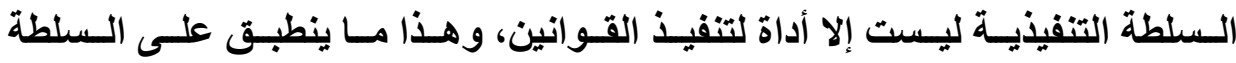

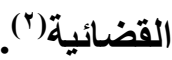

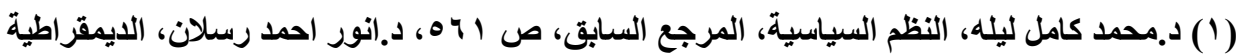

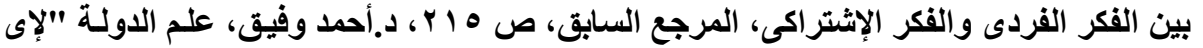

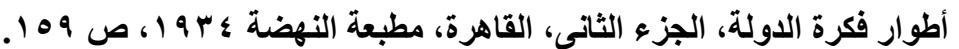

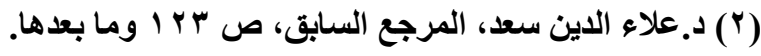


فالفصل الذى أقره روسو بين السلطات لم يمثل مبدأ قانونياً، إذ أن هذا الفصل لم يقم على أساس المساواة بين السلطات، حيث أن السلطة التشريعية هى مظهر السيادة الوحيد، وهذه السلطة يياشـرها الشعب وحده، ولا يمكنه التــازل عنها أو تجزئتها، فالفصل لم يكن سوى تقسيم عمل أو فصل بين الوظائف(') و الخلاصة أن روسو لم يعتنق مبدأ الفصل بين السلطات، وذلك بناءً على نظريته عن السيادة التى تعكس إرادة مجموع أفراد الشعب، وهذا ما ميزها بعدم التجزئسة وعدم القابلية للتنازل، وهذا ما أستتبع تركيزها فى سلطة واحده ألا وهى السلطة التشريعية بإعتبارها ممثله لمجموع الثعب لايه، وهذا مارتب هيمنة السلطة التشريعية على باقى السلطات الاخرى، و هذا ما يتعارض مع مبدأ الفصل بين السلطات.

\section{المطلب الثالث}

\section{هونتسكيه والفصل بين السلطات}

بالرغم من أن أفكار مونتسكيه عن الفصل بين السلطات لم تكن بـالامر الجديد، إذ توصل إليها العليد من الفلاسفة السابقين عليه، إلا أنه أكسبها خصائص وبلورها

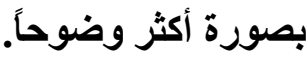

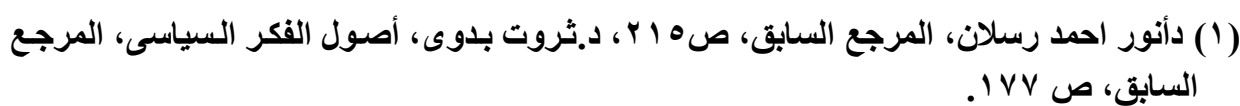
Vedel "G": Manuel elementaire de droit constitution, paris, 1949, p. 21. 
فنجد لوك وقد توصل للفصل ببين السلطات قبل مونتسكيه، كمـا أن مونتسكيه

نفسه كان من أثد المعجبين بشخصيته وأفكاره، إلا أنه أستطاع أن يطور من أفكار لوك بحيث أصبحت على يده من أهم مبادئ المذهب الحر فى الفكر السياسى (').

وبناءً على ما سبق ولتوضيح مبدأ الفصل بين السلطات لاى مونتسكيه، نتناول

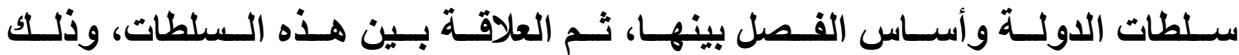
فيما يلى:

الفرع الأول: سلطات الدولة وأساس الفصل بينها. الفرع الثانى: العلاقة بين سلطات الدولة.

\section{الفرع الأول}

\section{سلطات الدولة وأساس الفصل بينها}

عدت أفكار مونتسكيه عن الحرية من أهم الأفكار التى تناولها، وقد أثرت على

أفكاره السياسية و القلسفية(؟)، وذلك فى سبيل تحقيقها وصونها.

وقد تأثر مونتسكيه فى ذلك بالظروف السياسية والاجتماعية السائده فى فرنسا أنذا(ك، إذ ساد الحكم الإستبدادى المطلق فيها بمـا تتضمنه من مساوئ وإعتداء على حريات الأفراد، مما دعى مونتسكيه لمحاولة مقاومته والتخلص منه(").

(1) د.فضل الله إسماعيل، المرجع السابق، صه هوما بعدها. د.محمد طه بدوى، أصول علم السياسة،

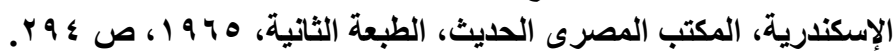

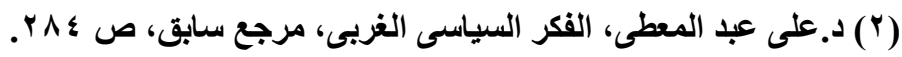
(T) د.فضل الله إسماعيل، المرجع السابق، ص VIVا. 
وقد شرع فى تحديد مفهوم الحرية العياسية بداءة، وذلك فى سبيل بنـاء نظرية على أسس سليمة، إذ أن كلمة الحرية تتضمن العديد من المعانى، بحيث تشمل العديد

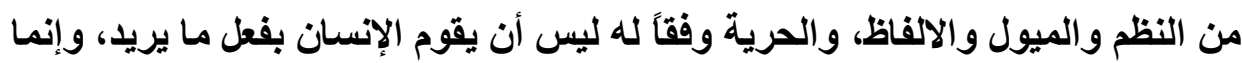
أن يقوم الإنسان بفعل ما يريد فى حدود مـا تسمح بـه القوانين، بالإضـافة لعدم إجباره

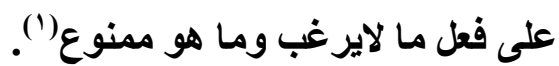
ومفاد ذلك أن مونتسكيه جعل من القوانين أسـاس حريـة الأفراد، ولذا فبإذا قام أحد الأفراد بفعل مـا تجرمه القو انين، فإنه يفقد حريته. وفى سبيل الحصول على حريـة الإنسان السياسية والحفــاظ عليها، أوجب مونتسكيه أن تتذذ الحكومة شكلاً خاصاً يتمتع فيه الفرد بحريته دون خوف، هذا النظام النسام

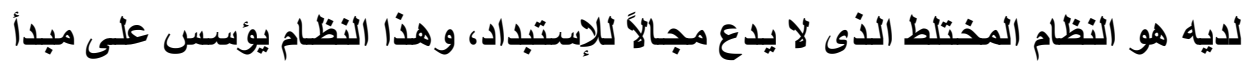
الفصل بين السلطات المختلفة(؟).

فمونتسكيه رأى أن الفصل بـين السنطات هـو السبيل الوحيد لـصون حريـة الأفراد، وذلك تأسيساً على أن الفرد يتصف بأننيته وحبه للتسلط، فإذا مـا تمتع بسلطة منفرداً سعى إلى التعف فى إستعمالها، وهو فى هذا التعسف والتسلط لا يتوقف إلا إذا

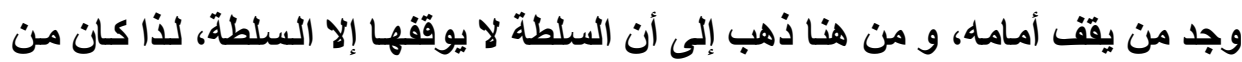
الطبيعى فى سبيل الدد من السلطة ومنع الإستبداد فصل سلطات الدولة، حيث إذا تولت هيئة واحده كافة السلطات سعت إلى الإستبداد.

(1) Montesquieu: The spirit of laws, translated by Thomas Nugent, new York, hadner publishing, co, 1949, p. 214.

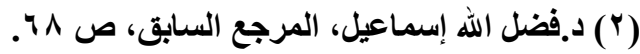

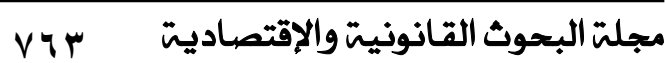


كما ذهب إلى أن الحرية لا يمكن أن توجد فى ظل إجتماع السلطتين التشريعية والتفيذية فى يد هيئة واحده، وذلك بسبب أن إجتماع هاتين السلطتين فى يد واحداه

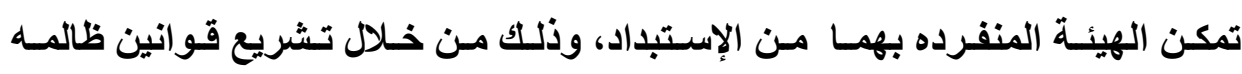
وتنفيذها بصوره ظالمه أيضاً.

هذا بالإضـافة إلى أنسه لا حريـة فى ظل عدم إنفصال السلطة القضائية عن السلطتين التشريعية والتنفيذية، إذ أن ذلك يؤدى إلى أن السلطة على على حريات الأفراد وحياتهم تحكمية، حيث أن القاضى يجمع بين القضاء والتشريع (') وبناءً على ما سبق فرق مونتسكيه بين سلطات ثلاث فى الدولة، هذه السلطات

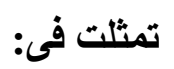
|-السلطة التشريعية: وهى تختص بإصدار قواعد تتخذ شكل نصوص

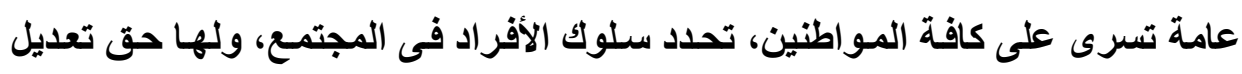

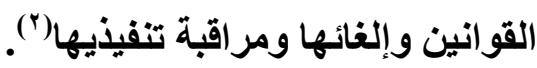
وقــ ذهـب مونتـسكيه إلسى أن السلطة التشريعية تتكسون مسن مجلـسين، أولاهما مجلس ديمقراطى يتضمن نواب ممثلين للثعب، يتم إختيار هم بواسطة الإقتراع

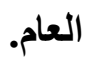

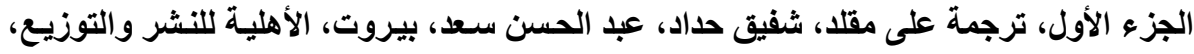


وثانيهما مجلس إرستقراطى يتضمن النبلاء، ويتصف بأتهه وراثى، وقد أسس

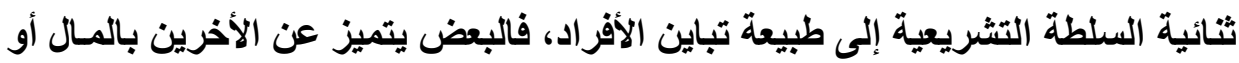
تملكهم مصالح خاصة تتيح لهم إمكانية الدفاع عنها. وهذا ما دفع مونتسكيه إلى إنثاء مجلس أرستقراطى بجاتب المجلس الشعبى، إلا أن هذين المجلسين لهمـا إختصاصات متساوية، إلا فى حـال التعارض فيمـا بينهر فتعلو سلطة المجلس الشعبى، إذ يقتصر حق المجلس الإرستقراطى على الإعتراض فقط ')

r-السسلطة التنفيذيسة: وهى تختص بمسائل الحرب و السلام، وإستقبال وإرسال البعثات الدبلوماسية، هذا بالإضافة لواجبها فى حفظ الأمن الداخلى، وذلك من

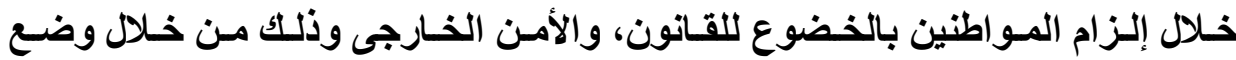

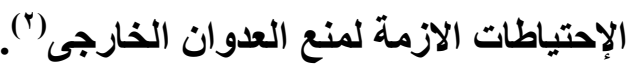
والسلطة التنفيذية يهيمن عليها الملتك، حيث إن الحرية لا تتحقق حال جمع السلطة التشريعية بالسلطة التنفيذية فى يد واحده، كما أنه من المستحسن تركيز سلطة الإدارة فى يد شخص واحد، إذ أن قدرة الفرد على الإدارة أفضل بكثير من قدرة عدد ليد

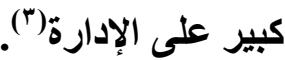

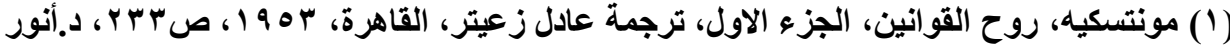

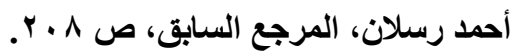

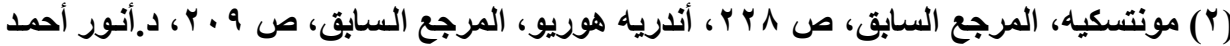

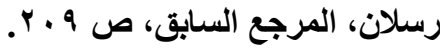

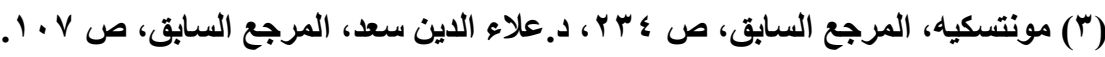


r-السلطة القضائية: وتختص بالفصل فى المنازعات التى تثور فيمـا بين

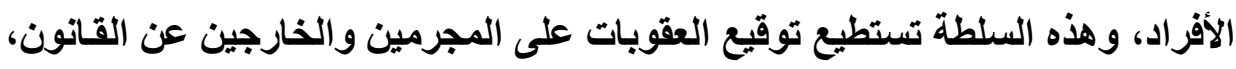
وتتكون السلطة القضائية من قضاه منتخبين من قبل الشعب، وذلك فى سبيل أداء

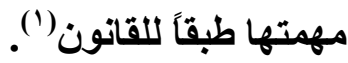
وتجدر الإشارة هنا إلى أن مونتسكيه قد خالف لوك فى تقسيمه لسلطات الدولة،ة وذلك من حيث أن مونتسكيه أعتبر السلطة التنفيذية والإتحادية سلطة واحده، وذلك التكان بخـلاف لـوك الذّى رأى أنهــا سـلطتان مستقلتان، كمـا أن مونتسكيه جعل السلطة القضائية سلطة مستقلة، فيما ذهب لوك أن سلطة القضاء الخاصة بتطبيق القوانين المدنية تتدرج ضمن اختصاص السلطة التنفيذية، بينما القضاء الخاص بجرائم الأفراد فيندرج ضمن اختصاص السلطة التثريعية(') ويعد هذا التقسيم الثلاثـى لسلطات الاولـة لـدى مونتسكيه قاعدة دستورية أعتنقتها غالبية الأنظمة الدستورية الحديثة"("). ومفاد ما سبق كله أن مونتسكيه قد أعتثق مبدأ الفصل بين السلطات الثلاث التى

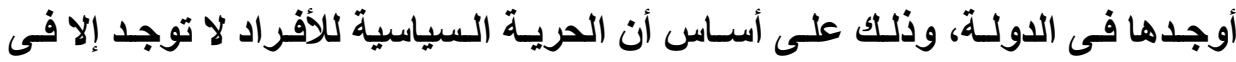

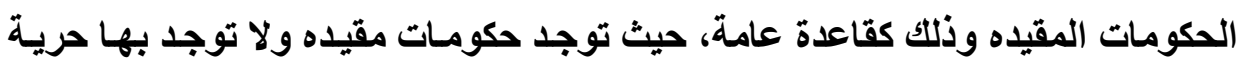

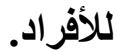

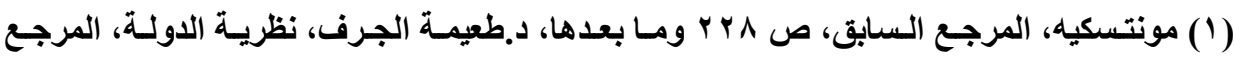

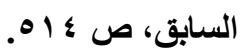

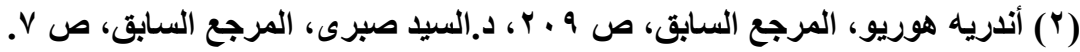

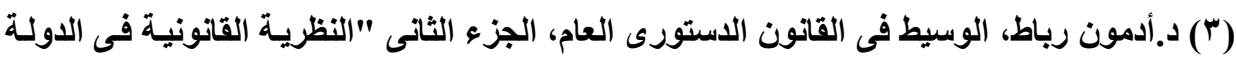

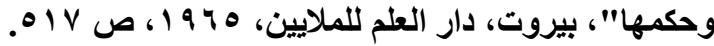


فمبدأ الفصل بين السلطات لاى مونتسكيه يهذف إلى عدم استباداد أحد بالسلطة

أو أن يسئ أحد استعمال سلطته، بحيث أصبح مبدأ الفصل بين السلطات لايـه السبيل الوحيد لكفالة إحترام القوانين وتطبيقها تطبيقاً صحيحًَ'(') فوفقاً لرأى مونتسكيه فِان الحريـة السياسية للأفراد لا تتحقق فى ظل اجتمـاع السلطتين التشريعية والتنفيذية فى يد هيئة واحده، حيث يمكنها أن تضع قوانين طاغية وتطبقها بصورة طاغية أيضًاً().

وتطبيقـاً لـذلك ذهب مونتسكيه إلسى عـدم جـواز الجمـع بـين منـصب الـوزارة وعضوية البرلمـان، إذ ان فـى هـذا الفـرض سـيجمع الفـرد بـين ممارسـة السلطتين

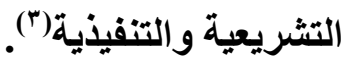
وقد طبق هذا المبدأ على السلطة القضائية أيضاً، وقد رأى أن اجتمـاع السلطات الثثلاث فى يـلـ شخص أو هيئة واحده، يعرض حيـاة وحريـات الأفراد للإنتهاك بل إلى لى الضياع(؛)

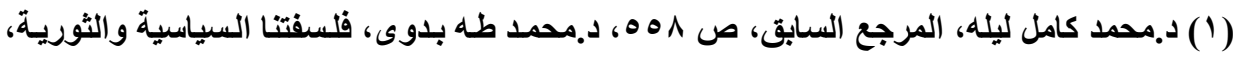

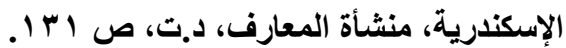

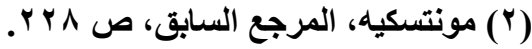

Esmien(A): op. cit, p.499.

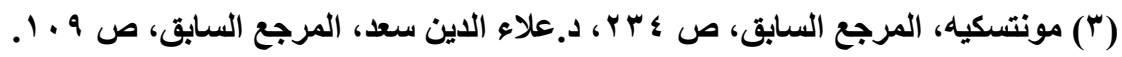

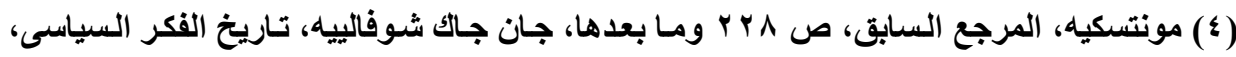

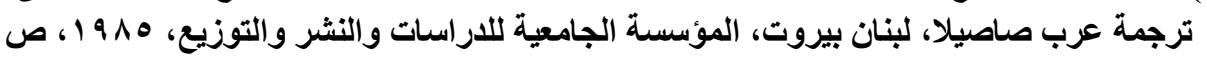

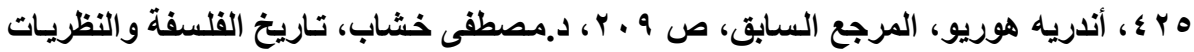

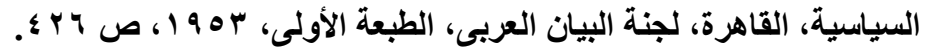




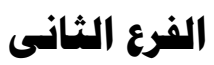 \\ العلاقة بين سلطات الدولة}

أعتنق مونتسكيه مبدأ الفصل بين سلطات الدولة، وذلك ضماناً لتحقيق الحرية السياسية للأفراد، وقد أوجد فى الدولـة ثلاث هيئـات تمثلت في السلطة التشريعية و التنفيذية والقضائية.

إلا أن مونتسكيه لم يقف عند ذلك الأمر بل ذهب إلى أن ذلك ليس كافياً لضمان

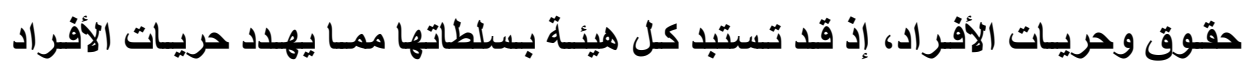
وحقوقهم، بل ويهدد السلطات الأخرى كذلك (')

وضماناً لحقوق الأفراد وحرياتهم أكمل مونتسكيه مبدأ الفصل بين السلطات لديه، بتوضيحه العلاقة بين سلطات الدولة، بحيث أوجب ضرورة التعاون فيمـا بينها،

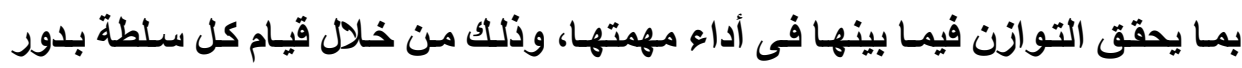

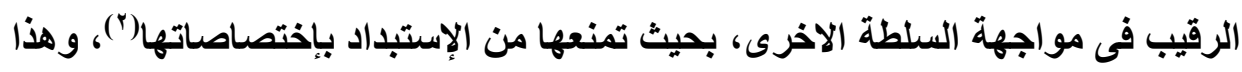
تطبيقًا لمقولته السلطة توقف السلطة.

وتطبيقاً لذلك وضع مونتسكيه نظاماً مرناً يسود بين السلطات، هذا النظام يقوم على أساس التعاون وتحقيق التوازن بين السلطات، وذلك من خلال:

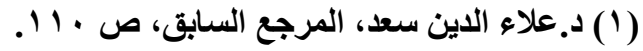

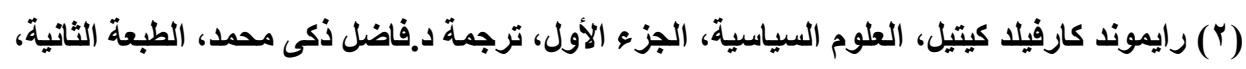

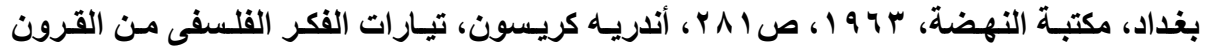

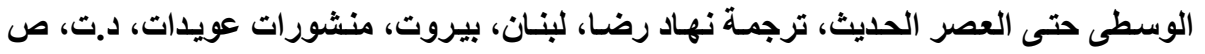

Vedel(G): op. cit. p.19 et. S.

VY1 مجلتّ البحوث القانونيت والإقتصاديت 


\section{أولاً: إشراك السلطة التنفيذية فى همارسة السلطة التشريعية لوظيفتها:} أوجد مونتسكيه وسيلة لإشراك السلطة التنقيذية فى أعمال السلطة التشريعية، من خلال تخويله حق السلطة التتفيذية فى دعوة السلطة التشريعية للإجتماع، وتحديد مدة الإجتماع وذلك بحسب ظروف وأحوال البلاد (') وقد أسس ذلك الامر على العديد من الأسباب من أهمها(")، أن ترك تحديد ميعاد

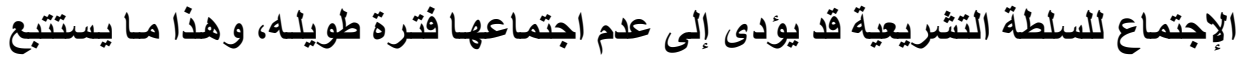

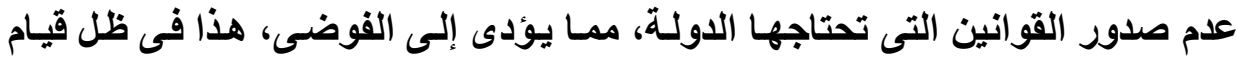

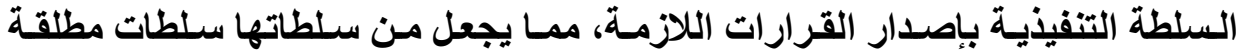
لجمعها بين السلطتين التنفيذية والتشريعية. كما قد يحدث العكس بحيث أن ترك ميعاد الإجتماع للسلطة التشريعية قد يؤدى

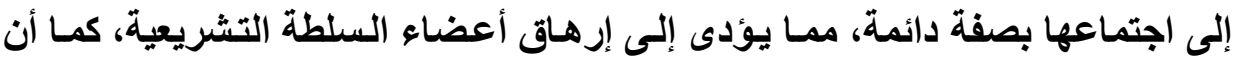

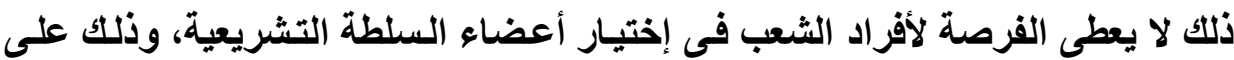

$$
\text { نحو يحقق أمالهم وطموحاتهر. }
$$

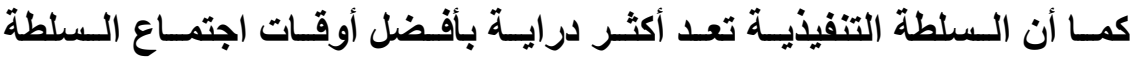
التشريعية، لذا وجب ترك هذه السلطة لها لتحقيق صالح الدولة. وبجانب حق السلطة التنفيذية فى دعوة السلطة التشريعية للإنعقاد، منحت حق الإعتراض على القوانين الصادره مـن السلطة التشريعية، وذلكت على أسساس عدام صلاحيتها").

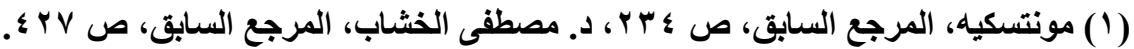

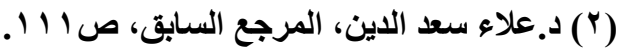

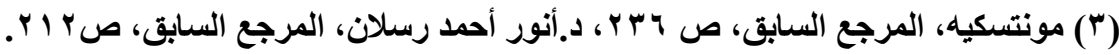
Vedel(G): op.cit.p.19et .s.

Vج مجلت البحوث القانونيت والإقتصاديت 
وقد برر مونتسكيه هذا الحق على أسساس أن عدم منح السلطة التنفيذية هذا

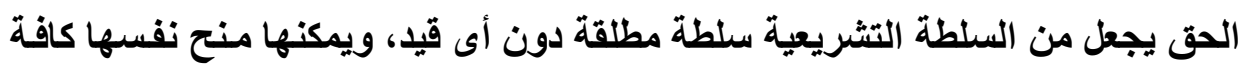
السلطات أو يمكنها تدمير باقى السلطات.

وبالرغم من هذا الحق للسلطة التنفيذية، إلا أن مونتسكيه يثدد على أن السلطة

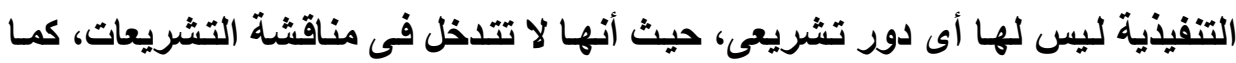
ليس لها إقتراح التشريعات، فكل ما لها هو حق الإعتراض أو رفض القوانين التى لا لا لهان

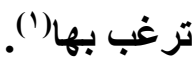

\section{ثانياً: حقوق هراقبة السلطة التشريعية لاتنفيذية:}

فتحقيقًاً للتـوازن بـين السلطات كمـا دعسى إليسه مونتسكيه، منحست السلطة

التشريعية حقوق فى مواجهة السلطة التنفيذية، وذلك مقابل حقوق السلطة التنفيذية فى

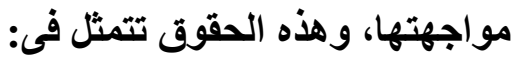
ا ـ حق السلطة التشريعية فى مراقبة أعمال السلطة التنفيذية، وإثرافها على كيفية تطبيقها للقانون(") ץ ـ حق السلطة التشريعية فى مسائلة الوزراء، وذلك على أسساس أن الرقابة تمسارس

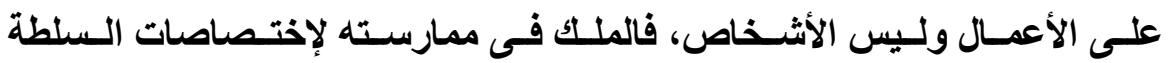

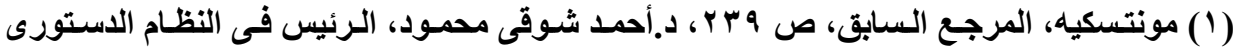

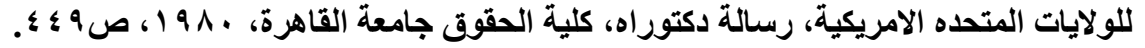

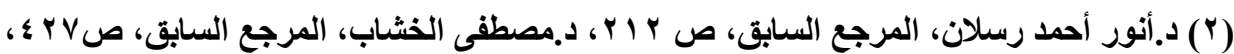

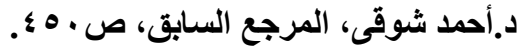


التنفيذية يستعين بوزراء، ومن ثم يكونوا هم المسئولين عن أعمالهم أمام السلطة

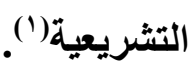

ץ- حق السلطة التثريعية فى تحديد نفقات السلطة التنفيذية سنوياً، بالإضـافة لحقها فى تحديد ما يلزمها من قوات للحفاظ على حريات الأفراد(").

وبناءً على ما سبق أوجد مونتسكيه توازن بين السلطتين التثريعية والنتفيذية،

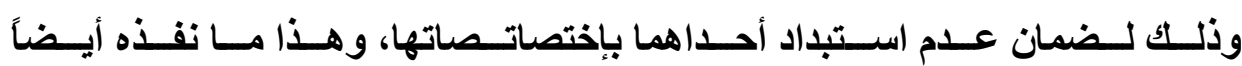

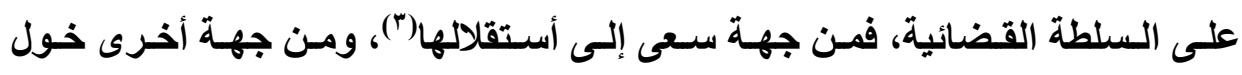
للسلطة التشريعية حق التدخل فى أعمالها، ولكن فى حالات محدده، وهذه الحالات تمثلت فى (4):

1 - هماكمة النبلاء: إذ جعل محاكمة النبلاء تتم امسام مجلسهم الذى يمثل المجلس

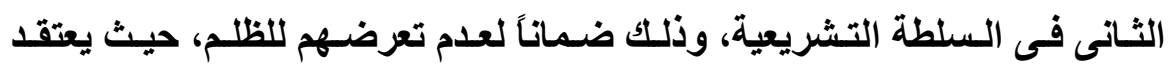
مونتسكيه أن العظماء عرضه للحسد دائماً، لذا يجب محاكمتهم أمام أمثالهم. ومما لا شكك فيه أن هذا الامر يعكس انحيازاً لطبقة النبلاء أو الإرستقراطية. r-تعديل القانون: فقد تعرض حالة على القضاء يتضح منها أن العقوبات المقرره لها تتسم بالشده والقسوه، وحيث أن القضاء لا يملك حق تعديل القانون رغم

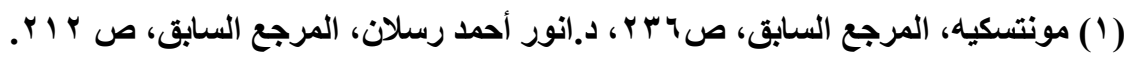

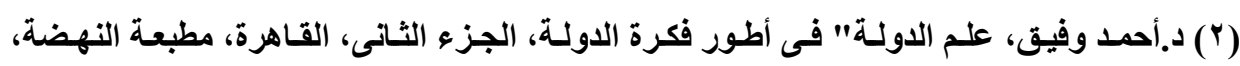

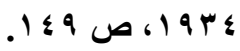

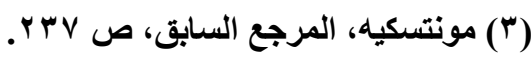

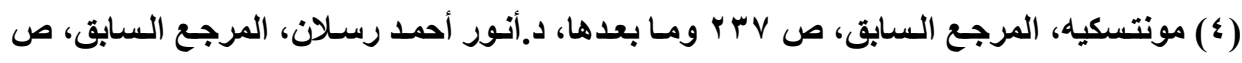


قسوته، فالمجلس التثريعى هنا يتحول إلى محكمة ويحق لله تعديل القانون طبقاً للصالح العام.

r- توجيه الإتهـام: حيث منح للسلطة التشريعية سلطة الإتهام، وذلك فيمـا يخص الجرائم التى تمثل عدواناً على حقوق الثعب، أو الجرائم السياسية، وذلك حفاظًا على كرامة الثعب.

وبالرغم من ذلك إلا أن السلطة القضائية تمتعت بالإستقلال، كمـا أنها وتطبيقًا للتوزان بين السلطات منحت حق الإعتراض على القرارات الصادره مـن السلطة التنفيذية المخالفة للقانون(') - (')

ومفاد مـا سبق كله أن مونتسكيه قد أنتهج مبدأ الفصل بين السلطات، وذلك ضماناً لحرية الأفراد، وفى سبيل ذلك حدد مونتسكيه طبيعة العلاقة بين سلطات الدولة، وذلك على أساس قيام تعاون وتوازن فيما بينها. وتجدر الإشارة هنا إلى أن مونتسكيه بأفكاره هذه عد مرجعاً لمبدأ الفصل بين السلطات، وذلك بالرغم من أن العديد من سبقوه تعرضوا لذات الفرات الفكرة. إلا أنه ومن منطقق إهتمامه بحرية الأفراد فى ظل انتثار مبادئ المذهب الفردى

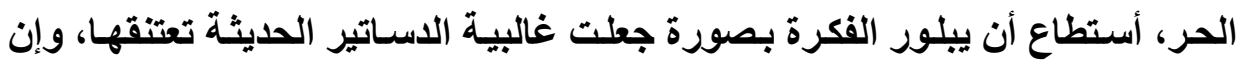
اختلفوا فى تطبيقها، وذلك بحسب ما سوف نراه فيما بعد. 


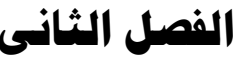

\section{التطبيق الدستورى للأساس الفلسفى لمبدأ}

\section{الفصل بين السلطات}

وجد مبـدأ الفصل بـين السلطات الـذى تـم بلورتـهـ نتيجـة للعديــ مـن الأفكـار

القلسفية_سبق تناولها-طريقه للتطبيق فى الواقع العملى، إذ ضمنت غالبية الدول مبلأ الفصل بين السلطات فى دستورها.

إلا أن هذا التطبيق شـهـ تبـاين مـن دولـة إلى أخرى، ومـن دستور إلى أخر،

وذلك وفقاً لظروف المجتمعات وتبعاً لمراحل التطور السياسى والاجتمـاعى، هذا بجانب موقف رجـال السلطة فيمـا يخـص العلاقـة بـين السلطات، وتفـسير رجـال القـانون

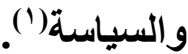

كمـا أن تطبيق المبدأ عملياً قد يظهر الاختلاف بين أساسيات المبدأ الفلسفية والواقع العملى، إذ قد تمر الدولـة بظروف حرب أو إنقلابـات، أو ثورات، ممـا قد يدفع إحدى سلطات الدولة إلى القمة والسيطرة على تسيير شئون الحكم وسلب إختصاصات

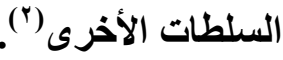

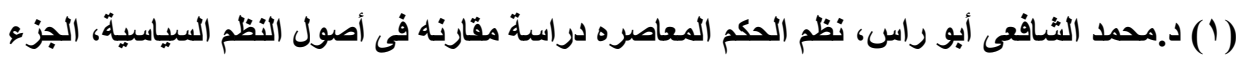

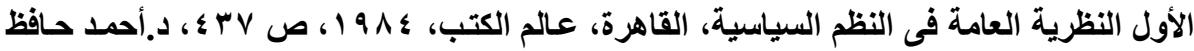
نجم، الفصل بين السلطات وتطور العلاقة بين السلطات التشريعية والتنفيذية فى الداستية التير المصرية،

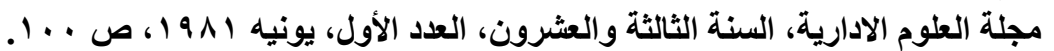

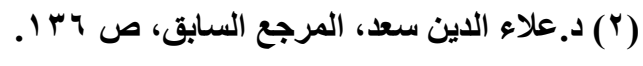


وقد استقر الفقه على التمييز بين عدة صور للأنظمة السياسية، وذلك بحسب

الفصل بين السلطات وما يقوم بين سلطات الدولة من علاقات وروابط، وهذه الصور

$$
\text { تمثلت فى: }
$$

ا_النظام البرلمانى.؟ -النظام الرئاسى.؟-نظام حكومة الجمعية النيابية.

وينـاءً على ذلـك نتنـاول التطبيق الاسـتورى لمبدأ الفصل بـين السلطات فى

هذه الصور الثثلاث، وإن كنـا نهـتم باللدول المتقدمـة، وذلك في سبيل سـعينا لمحاولـة التقرب منهم فيما ينفعنا، وذلك قبل تناول هذا المبدأ فى ظل الدستور المصرى، وذلك

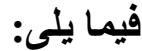

المبحث الأول: تطبيق الأسساس الفلسفى للفصل بين السلطات فى الأنظمة المختلفة.

المبحث الثانى: تطبيق الأساس القلسفى للفصل بين السلطات فى مصر. 


\section{المبحث الأول}

\section{تطبيق الأساس الفلسفى للفصل بين السلطات فى الأنظمة المنتلفة}

وجد تطبيق لمبدأ الفصل بين السلطات فى الأنظمة المختلفة، كمـا تم أعتنقه من قبل الدول المتقدمة، وذلك كضمان وتأكيد لمبـادئ الديمقراطية التى أعتنقتها هذه الدول، وقد تباين تطبيق هذا المبدأ من الناحية الدستورية، وذلك تبعاً للنظام السائد فى الدولة.

حيث إن تطبيق المبدأ أختلف فى النظم البرلمانية عن النظم الرئاسية، عن نظام حكومـة الجمعيـة النيابيـة، لذا سـوف نتنـاول تطبيق المبدأ فى ظل هذه النظم، وذلك فيما يلى:

المطلب الأول: الفصل بين السلطات لاى النظم البرلمانية. المطلب الثانى: الفصل بين السلطات لاى النظم الرئاسية.

المطلب الثالث: الفصل بين السلطات لاى نظام حكومة الجمعية النيابية.

$$
\text { المطاب الأول }
$$

\section{الفصل بين السلطات لدى النظم البرلمانية}

ساد النظام البرلمانى غالبية دساتير الديمقراطيات الغربية بالقارة الأوربيـة، إذ بإستثناء سويسرا أعتنقت كافة الدول الأروبية النظام البرلمانى، كما أعتنته العديد من

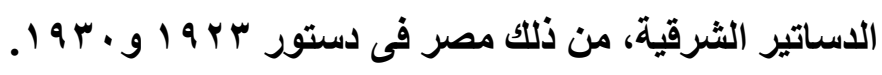




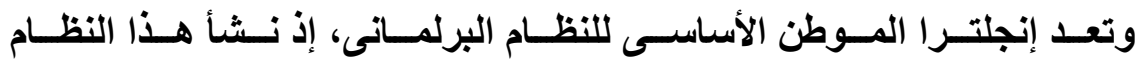

نتيجـة ظروف إجتماعيـة وسياسية فيها، ووفقاً لـلكـ حددت أسسـه العامـة وملامحسه

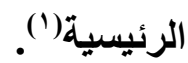

ويرجـع انتشار هذا النظام فى العديد مـن دول العـالم إلى إعتبـاره أكثر النظم الديمقراطية، كما أنه أكثر النظم تحقيقًا للتعاون والتوازن بين السلطات. ومفاد ذلك أن من أهم خصائص هذا النظام البرلمـانى إقامـة التوازن والتعاون بين السلطتين التشريعية والتنفيذيـة، إلا أن هذا التوازن قد تباين تطبيقه فى الواقع

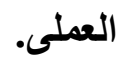
وبناءً على ما سبق نتناول الأسس النظريـة لمبدأ الفصل بين السلطات فى ظل النظم البرلمانية، ثم التطبيق العملى له، وذلك فيما يلى: الفرع الأول: الأسس النظرية للمبدأ. الفرع الثانى: التطبيق العملى للمبدأ. 


\section{الفرع الأول}

\section{الأسس النظرية للمبدأ}

عدت الخاصية الأساسية للنظام البرلمانى إقامة التوازن والتعاون بين السلطتين التشريعية والتنفيذية، إذ قامت العلاقة بين هـاتين السلطتين على أسـاس المساواة، أو بمعنى أخر إن مبدأ الفصل بين السلطات قد أتخذ شكل الفصل المرن المشوب بالتعاون والرقابة المتبادلة، وهذا ما يعكس أفكار مونتسكيه وأرائه. ويتضح ذلك من خلال إيجاد وسـائل للرقابـة والتوازن بين السلطتين التشريعية والتنفيذية، وهذه الوسائل تتمثل فى اتجاهين، أولاهما التوازن، وثثانيهما التعاون. أما من جهة التوازن فيحدث نتيجة منح كلا السلطتين حقوق فى مقابل الأخرى، ومن ذلك حثى البرلمان فى الإقتراع بعدم الثقة بـالوزارة، وذلك فى مقابل حق الحكومـة

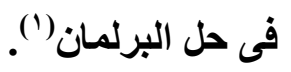

حيث أن الوزارة ممثل السلطة التنفيذية مسئوله عن تصرفاتها الخاصـة بإدارة شئون الدولة أمام البرلمان، إذ يجب أن تكون الوزارة حائزة على ثقة أغلبية أعضاء البرلمسان، وهذا الأمـر يسرى على مستوى الـوزراء كـلا على حده، وعلى مستوى الوزراء كافة بصفة تضامنية)(؟) وتطبيقاً لذلك لا يبقى الوزير فى منصبه حال فقده ثقة البرلمان، فإذا فقد الوزير الثقة وجب عليه الإستقالة، كما أن الوزارة إذا فقدت الثقة وجب عليها الإستقالة.

$$
\text { (1) د.محمد كامل ليله، المرجع السابق، ص V9 Vه وما بعدها. }
$$

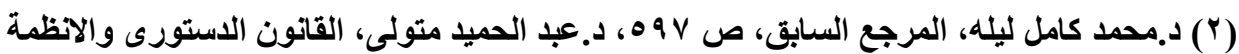

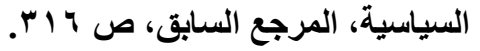


هذا الحق قابله حق السلطة التنفيذية فى حل البرلمان، فهذا الحق قد مثل سلاح السلطة التنفيذية فى مواجهة سلطة البرلمان فى سحب الثقة، فبدون هذا الحقى تصبح السلطة التنفيذية عاجزه فى مواجهة السلطة التشريعية، بحيث يقترب النظام من نظام

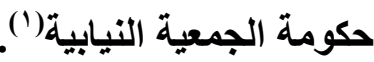

فالسلطة التنفيذيـة أمسا أن تخضع للسلطة التشريعية، وأمسا أن تستقل، وهذا الإستقلال قد ينثأ عنه اختلافها مع البرلمان، فقد ترى الوزارة أن سياستها التى تتبعها تعكس متطلبات المجتمع، وذللك بالرغم من مخالفتها لرأى البرلمان، و لايمكن الوصول إلى حل يرضى الطرفين، هنا قد يلجأ البرلمـان إلى سحب الثقة، و فى مقابل ذلكك تلجـأ السلطة التنفيذية إلى حق الحل، بحيث يصل الأمر إلى إجراء انتخابات جديده و إستطلاع

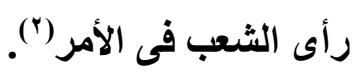

أما من جهة التعاون فقد قصد بـه إيجاد نوع من الإتصال بين السلطتين، فمن ناحية السلطة التنفيذية فقد منحت حق دعوة البرلمان للإنعقاد، بجانب حق الوزراء فى لهى دخـول البرلمسان والإثـتراك فى المناقششات، هذا بالإضـافة لحق الحكومسة فى تقديم

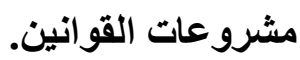

أمسا مـن ناحيـة السلطة التشريعية فقد منح البرلمـان حق توجيـه الأسـئلة و الإستجوابات للحكومة، كما يملك البرلمان حق تثكيل لجان للتحقيق فى أى تصرف من لن التحني

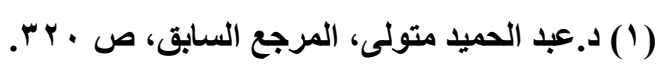

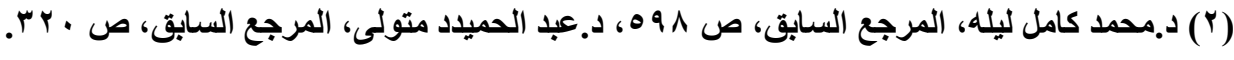


تصرفات السلطة التنفيذية، ليس هذا فحسب بل إن بعض الدسـتير تعطى للبرلمـان حق توجيه الإتهام الجنائى إلى رئيس الوزراء(').

وتجدر الإثـارة إلى أن هذه الحقوق المتبادلة قد خرجت عن أفكار مونتسكيه

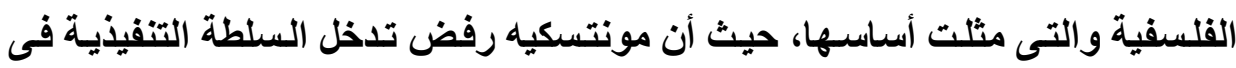

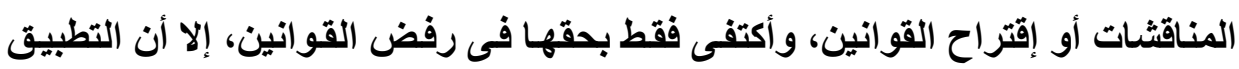
العملى أفرز هذا الحق، وهذا ما يمثل الإختلاف بين الأفكار والتطبيق.

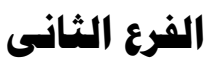

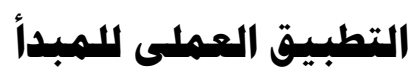

عـد التـوزان والتعساون بـين السلطتين التششريعية والتتفيذيـة أسـاس النظـام البرلمانى والصوره المثلى لمبدأ الفصل بين السلطات، وقد سـاد هذا الأمر فى النظام البرلمانى التقليدى الذى نثأ فى إنجلترا. وبالرغم من أن هذه الصوره تعد المثلى إلا انها لم تسنمر فى التطبيق، فنظراً لعلو مبادئ الديمقراطية، اختل التوازن وصب فى مصلحة البرلمان، كما أن هناك العديد من الاساتير منحت السيادة للسلطة التنفيذية(؟).

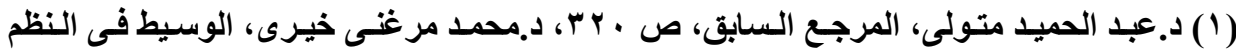

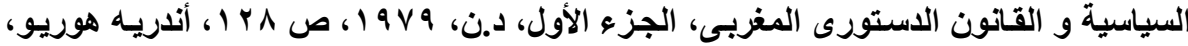

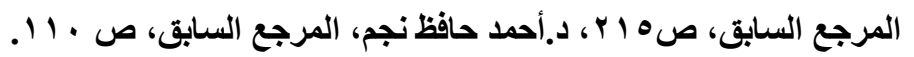

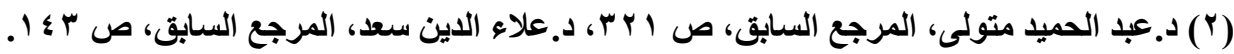


ومفـاد ذلك أن التطبيق العملى قد أظهر إختلال التوازن بين السلطتين، وذلك بخلاف ما تم النص عليه فى الدسـاتير، أو مـا دعى بـه الفلاسفة من أفكار حول مبدأ الفصل بين السلطات، هذا الإختلال قد يأخذ إحدى صورتين، تمثلا فى:

\section{أولاً: رجحان كفة السلطة التشريعية:}

فقى هذا الفرض يختل التوازن المفروض بين السلطتين التشريعية والتنفيذية، بحيث تصبح السلطة التثريعية هى صاحبة السلطة. ويرجع ذلك الخلل لمصلحة السلطة التشريعية لسببين، أولاهمـا جريـان العرف على علم استعمال حق الحل من قبل السلطة التنفيذيـة، بحيث تسلب السلطة التنفيذيـة أهـم حقوقهـا فـى مواجهـة السلطة التشريعية، وثانيهمـا، تعدد الأحزاب، إذ أن تعدد الأحزاب قا يؤدى إلى عدم استطاعة حزب واحد على الحصول على الإغلبية المطلقة، مما يستتبع تشكيل وزراة إيتتلافية، ولكن هذه الوزارة لا تتسم بالإنسجام إذ انها تشكل من أحزاب متنافسه، ممـا يوصمها بالضعف وعدم الإستقرار، حيث أن هذه الوزارة كثيرة السقوط بسبب انفصام عرها بين عدة أحزاب(').

ويتسم النظام البرلمانى فى ظل هذا الوضع بالضعف والعجز، إذ أن الوزارة لا تستطيع القيام بتنفيذ سياسه واضحه متسقه طويلة الامد، فالوزارة تعدل على فض مـا يقوم من نزاعـات بين أعضائها، إلا أن هذه المساوئ لا تؤثر بذات الارجه فى كافة الأنظمة، إذ أن الأنظمة ذات الاحزاب المتعدده أو الوزارت الإتتلافية، قد تتضمن وجود حزب قوى حائز على عدد كبير من المقاعد وإن لـ يصل إلى الأغلبية، إلا أن ذلك قد يرتب بعض من الإستقرار الحكومى.

(1) د د.عبد الحميد متولى، المرجع السابق، ص ابY.

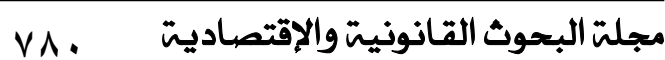


كما أن عدم وجود منافسات بين الاحزاب المختلفة ذى طبيعة مذهبية ونظريـة، بالإضـافة إلى الطـابع العلى والفنـى للمناز عـات السياسية قد يرتب الإستقرار بين

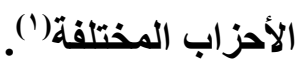

وتجدر الإثــارة إلى أن كافـة مسساوئ رحجـان سـلطة البرلمسان على السلطة التتفيذية، قد تبلورت فى فثل تجربة فرنسا فى إعتناق النظام البرلمانى، وذلك تطبيقًاً للاستور ها الجمهورى Avo ام، فمن جهة أقر هذا الاستور للبرلمان حق تعيين رئيس الجمهورية، وهذا ما رتب ضعف مركز رئيس الجمهورية، وعدم إستطاعته القيام بدور

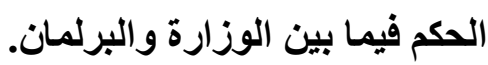
ومن جهة أخرى فقد وجدت العديد من الاحزاب السياسية، لم يستطع أحدهم الإستحواذ على الأغلبية البرلمانية لتمكنه من تكوين وزارة متجانسه، وهذا مـا أستتبع تكوين وزارات إئتلافية، اتسمت بقصر مدتها لكثرة مشاكلها("). ثانياً: رجمان كنة السلطة التنفيذية: فى مقابل معرفة الواقع العلى رجحسان كفة السلطة التشريعية متمثلـه فى البرلمان على سلطات الدولة، عرف الواقع العملى أيضا رجحان كفة السلطة التنفيذية. وتجدر الإثسارة إلى أن السلطة التنفيذية فى ظل النظام البرلمسانى تتشكل من عنصرين أحدهما هو رئيس الدولـة سـواء كسان ملكسا أو رئيس جمهوريـة، وثثانيههـا

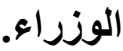

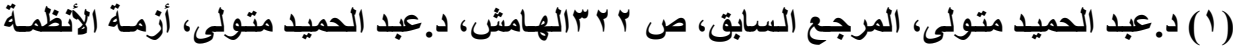

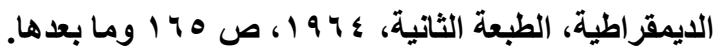
(r) د. علاء الدين سعد، المرجع السابق، ص ب ؟ ا. 
أما من جهة سيطرة الوزارة، فتحدث عندما تمتلك الوزارة السلطة الفعلية، وذلك تأسيساً على استنادها إلى حزب منظم قوى حائز على الأغلبية البرلمانية، وهذا الامر هو ما شهده الواقع الإنجليزى، وذلك منذ عهر الملكه فيكتوريا'ا'. أمسا مـن جهة سيطرة رئسيس الاولـة، فتتبلور حسال اتسام الـوزارة بالـضف، بالإضافة إلى اعتناق مبأ أن الوزارة يجب ألا تكون حائزه فقط على ثقة البرلمـان، بل يجب أن تحوز ثقة رئيس الدولة، إذ يكون لهه حق إقالة الوزاره حال فقده الثقة فيها،

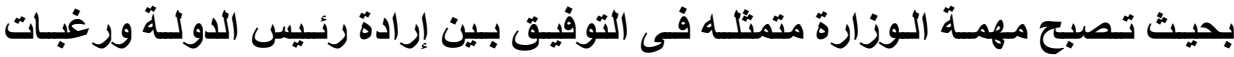
البرلمان، وهذا ما شهده الواقع الفرنسى فى عهل الملك لويس فيليب(").

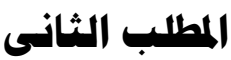

\section{الفصل بين السلطات لدى النظم الرئاسية}

عد النظام الرئاسى نظامًا أمريكياً، إذ نثأ هذا النظام فى أمريكيا عقب الإستقلال مباشرة، إذ نص أول دستور للبلاد عام VNVV ام على إعتناق هذا النظام ("). وقد تتضمن هذا النظام العلاقة بين سلطات الدولة، بحيث أقر مبدأ الفصل بين السلطات، إذ أن واضعى الستتور أعتبروا مبدأ الفصل عقيدة وجب إتباعها فى سبيل الحفاظ على حريات الأفراد، ومنع الطغيان و الإستبداد.

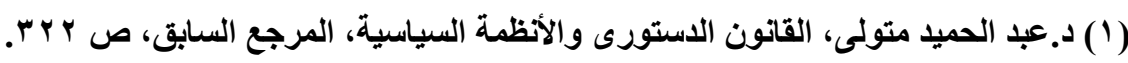

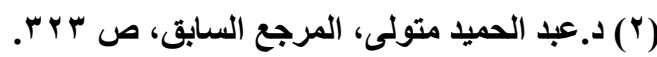

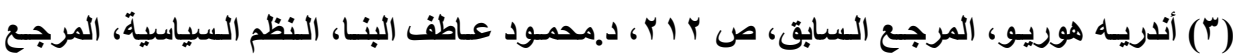
السابق، ص 9 ه ؛ ، د.طعيمه الجرف، نظرية الدولة، مرجع سابق، ص ؛ ؟ به. 
وإن أعتنقوا المبدأ فى صورته المطلقة، إذ وزعت السلطة على ثُلاث سلطات

وجد بينهم فصل تام، بحيث لا وجود لأى تعاون أو إندماج، كما لا وجود لسيطرة سلطة

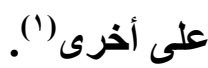

وتجدر الإثارة هنا إلى أن هناك فارق جلى بين نصوص الاستور كمـاوضعت،

وبين التطبيق العملى لها()، وذلك على الاخص فيما يتعلق بمبدأ الفصل بين السلطات "محل البحث".

وبناءً على ذلك نتناول الأسس النظرية للفصل بين السلطات فى النظام الرئاسى، ثم التطبيق العملى لهه، وذلك فيما يلى: الفرع الأول: الأسس النظرية للمبدأ. الفرع الثانى: التطبيق العملى للمبدأ.

\section{الفرع الأول}

\section{الأسس النظرية للامبدأ}

تتضمن النظام الرئاسى تنظيم للعلاقة بين سلطات الدولة المختلفة، والمتمثله فى

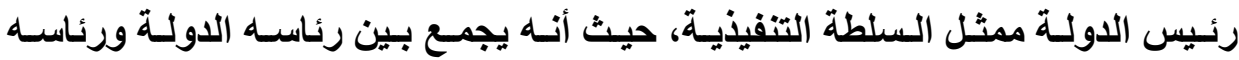
الحكومـة، والـسلطة التشريعية ممثلــه فـى مجلـسيها النـواب والـشيوخ، والـسلطة القضائية)(")

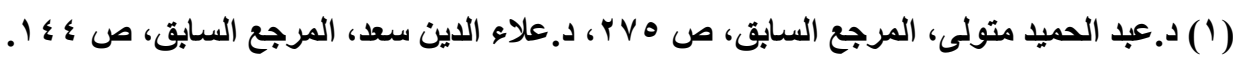

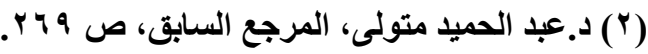

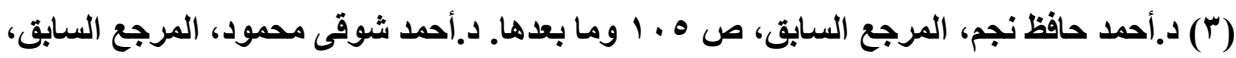
ص • • إ وما بعدها. 
وقد قام هذا التظيم على أسساس الفصل التام أو شبه التام بين هذه السلطات، بحيث تستقل كل سلطة عن الاخرى فى مباشرة إختصاصاتها. وتطبيقًا لذلك لا يجوز للسلطة التنفيذيـة التدخل فى أعمـال السلطة التشريعية، بحيث لا يحق لهـا دعوة المجلس للإنعقـاد أو فض دورة الإنعقـاد، كمـا لا يجوز حل الكونجرس "السلطة التشريعية" من قبل السلطة التنفيذية، هذا بالإضـافة لعدم جواز

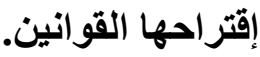

وفى مقابل ذلك فِإن السلطة التشريعية لا يحق لها مسألة الوزراء أو مناقشة سياستهم أو سـب الثقة منهم، كمـا لا يجوز للوزراء الجمع بين الـوزارة وعضوية

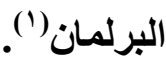

ومفاد مـا سبق أن النظام الرئاسـى قد أقر مبدأ الفصل بين السلطات بصورته المطلقة، إلا أن ذلـك لــ يمنـع مـن إقـرار بعض الإسـتثناءات علـى الفـصل التـام بـين السلطات، ويرجع ذلك إلى أن الغاية من المبدأ تتمثل فى صون الحريات ومنع الإستبداد، لـذا تـم إقرار الإسـتناءات خوفاً مـن الإستبداد سـواء مـن جهة السلطة التشريعية أو

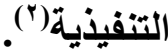
وقــ تمثلـت هـذه الإسـتثناعات فـى أثنـين هــا، أولاً: مـنح رئسيس الدولـة حـق الإعتراض على القانون الذى يوافق عليـه البرلمـان، هذا بالإضـافة إلى حق السلطة التنفيذية فى إصدار اللوائح(")

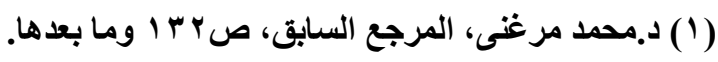

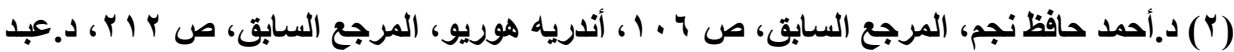

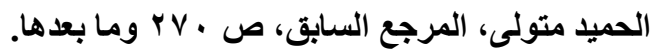

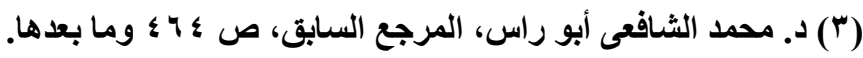


فقد منح رئيس الدولة حق الإعتراض على القوانين التى وافق عليها البرلمسان، و هذا ما أطلق عليه "حق الفيتو"، وذلك فى غضون مدة معينة، وذلك الحق عد سلاحاً فى يد رئيس الدولة للحيلوله دون استبداد أو طغيان السلطة التثريعية' (1). ويرجع هذا الإستثناء بالرغم من اعتباره خروجاً على مبأ الفصل بين السلطات بتدخل رئيس الدولة فى أعمال السلطة التثريعية، إلى أن الامريكان قد مروا بتجربة فى التى سبيل حصولهم على الإستقلال، تضمنت استبداد الفرد ممثل فى حاكم انجلترا أنذاك، و حكام المستعمرات البريطانيـة، كمــا تتضمنت استبداد البرلمسان مثثل فـى البرلمسان البريطانى حال طلبهم مطالب مشروعه فى سبيل الإستقلال، كمـا تتضمنت قيام الهيئات

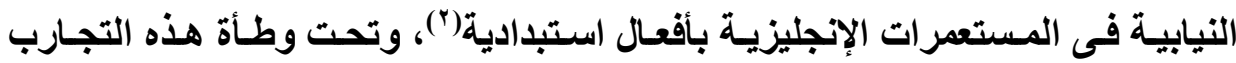

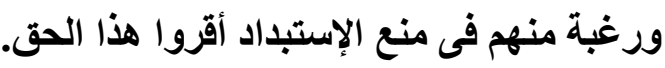

\section{ثانياً: إعتبار هبلس الشيوخ هبلساً تنفيذياً لرئيس الدولة:}

فى مقابل حق رئيس الدولة فى التدخل فى أعمال السلطة التشريعية، منحت

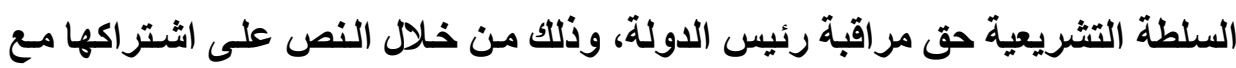
رئيس الدولة فى بعض الأعمال من ذلك ("):

1ـ تعيين الوزراء والسفراء وغيرهم من المثلين السياسيين، والقناصل والقضاه، وهذا الامر تقوم به السلطة التشريعية من خلال مجلس الشيوخ وذلك بإعتباره

مجلساً تنفيذياً.

$$
\begin{aligned}
& \text { (1) د.عبد الحميد متولى، المرجع السابق، ص rVV وما بعدها. }
\end{aligned}
$$

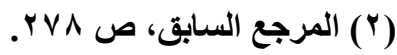

$$
\begin{aligned}
& \text { (r) المرجع السابق، ص r^v }
\end{aligned}
$$$$
\text { VAo مجلتّ البحوث القانونيت والإقتصاديت }
$$ 
وتجدر الإشارة هنا إلى أن موافقة مجلس الثيوخ تقتصر على التعيين فلا تمتـ للعزل، كما أنه من المستقر ومن باب المجامله ألا يعترض مجلس الشيوخ على اختيار الرئيس لأعوانه من وزراء، وقد مثل هذا عرفاً يتنهجه الأفراد منذ صدور الدستور. r ـ موافقة السلطة التشريعية ممثله فى مجلس الشيوخ على المعاهدات التى يبرمها

$$
\text { رئيس الدولة مع الدول الاجنبية. }
$$

وهذا الامر هو ما برر رفض امريكا معاهدة فرساى بعد الحرب العالمية الأولى، إذ أنـه بـالرغم مـن موافقة الرئيس "ولسن" عليها، إلا أنهله لم يستطع الحصول على موافقة مجلس الثيوخ(') ومفاد ما سبق كله أن النظام الرئاسى قد تضمن مبدأ الفصل بين السلطات، وذلك على أساس إعتباره دعامه من دعامـات حريات الأفراد، وإن لـم يعكس أفكار مونتسكيه بشكل صحيح، وذلك بإعتناقه المبدأ بصورته المطلقة، وذلك نتيجة للتجارب التى مر بها واضعوا الاستور المتضمن النظام الرئاسى.

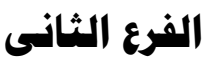

\section{التطبيبق العمطى للامبدأ}

تتضمن النظام الرئاسى مبدأ الفصل بين السلطات فى صورته المطلة، حيث لم توجـأى هيمنـه لسلطة على أخرى او تعـاون بينهم، وهذا مـا تقرر وفق المبـادئ النظريةكما سبق الذكر-، إلا أن الواقع قد شهـ اختلافً فى التطبيق، حيث سـادت علاقة

$$
\text { (1) المرجع السابق، ص Y و وما بعدها و هامشها. }
$$

BarthelemyTraiteelementaire de droit constitutionnel. 1933, p.153

VA مجلتّ البحوث القانونيت والإقتصاديت 
تعاون بين السلطات المختلفة ليتحول تطبيق المبدأ من الصورة المطلقة إلى الصورة

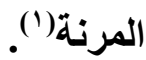

ومسن مظـاهر هـذا التعـاون أن الواقع العملى شـهـ مـنح الـرئيس حقى تتبيـه الكونجرس إلى أن موضوع معين فى حاجها إلى تلدخل تشريعى، كما منح حق وضع الميزانية العامة للإتحاد، هذا بالإضافة لتفويض الرئيس فى التشريع فى أوقات الأزمات

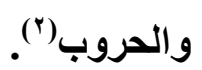

ليس هذا فحسب بل منح أعضاء السلطة التنفيذية حق المشاركة فى مناقشات القوانين أو الإعتمادات المالية الدائرة داخل لجسان الكونجرس لتوضيح وجهة نظرهم، وهذا فى مقابل خضوعهم للتحقيقات التى تجريها هذه اللجان (ז). ومفاد ذلك أن التطبيق العملى لمبدأ الفصل بين السلطات قد شـهـ تعاونـاً بين السلطات، وذلك بخلاف النصوص التى أعتنقت الفصل المطلق بينها. ويكمن سـر هـا التحـول مـن الصوره المطلقة إلى المرنـة لمبـأ الفصل بـين السلطات فى النظام الرئاسى الأمريكى فى ثلاث عوامل، تمثلت فى (؛)؛

(1) burdeau: Manuel droit constitutionnel et institutions politiques, paris, 1959, p. 207 et .S.

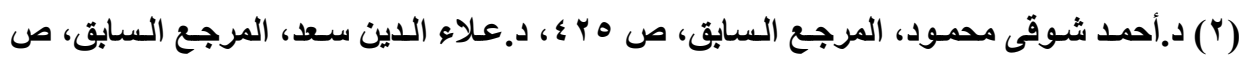

Vedel(G): op .cit. p.68.

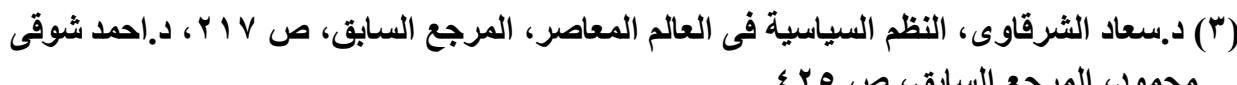

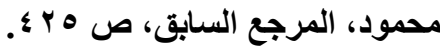

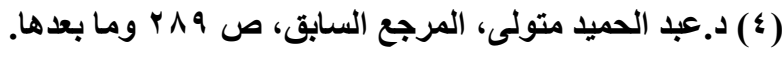


أولاً: ظهور الأحزاب السياسية، حيث أن الأحزاب لم تكن معروفه وقت إنشاء الدولـة ووضع دستور IVAV ، حيث تمثلت رغبة واضعى الاسستور فى عدم وجـود احزاب، لما كان لايهم من صوره تبعد الخير فيها.

إلا أنه لم يمض فترة حتى تكونت الاحزاب، بل أصبح رئسيس الدولـة أحل زعمـاء الحزب الحائز على أغلبية البرلمان، لذا كسان من الطبيعى وجود تعاون بين السلطتين التنفيذية ممثله فى رئيس الدولة وحزبه فى السلطة التشريعية. ثانيساً: اقتراح القوانين: حيث كـان لظهور الأحزاب وتمثيل رئيس الدولـة كزعيم لحزب الأغلبية أثره فى إستقرار العرف على تقديم مشروعات للقوانين. فإذا كاتت النصوص لم تمنح السلطة التنفيذية حق إقتراح مشروعات القوانين، فإن الواقع شـهـ قدرة رئيس الدولة على إقتراح القوانين، وذلك بواسطة أحد رجـال حزبه من أعضاء البرلمان.

فالرئيس هو زعيم الحزب الحائز على الأغلبية يستطيع من خلالهم تقايم ما يراه

$$
\text { من قوانين للبرلمان. }
$$

ثالثا: اللجان البرلمانية: شهد الواقع العملى إنشاء العديد من اللجان التى لم تدر فى ذهن واضعى الاستور، إذ ان هذه اللجـان نشئت تحت مظلة البرلمـان من خلال

$$
\text { اللوائح وليس الدستور. }
$$

وتقوم هذه اللجـان بتحضير مشروعات القوانين فـى البرلمـان، بـل إن الواقـع شـهـ تركز النشاط الحقيقى فيها، إذ فى سـاحتها تتخذ القرارات الهامـة، وذلك على أسـاس أنها تقوم بالعديد من الأبحاث والمناقشات الدقيقية بغية الوصول إلى القرار

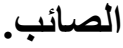


وقد شهـت هذه اللجـان تعاون بين الككومـة "السلطة التنفيذيـة" و البرلمـان "السلطة التشريعية"، إذ ان الوزير الذى يريد إصدار قـانون معين، يقوم بالإتصال برئيس اللجنة البرلمانية المختصة. كمـا أن هذه اللجـان تقوم بمراقبـة أفعـال الوزراء وأعمـالهم، إذ لها إستـاعاء الوزير أو أى من الموظفيين لمسألتهم عن تصرفاته، وهذا مـا يمثل رقابة من السلطة التشريعية على السلطة التنفيذية. فمفاد ذلك أن اللجـان البرلمانية عدت حلقة اتصال وأداة التعاون بين السلطة التنفيذية ممثله فى الرئيس ووزرائه من جهة، والسلطة التشريعية ممثله فى البرلمسان

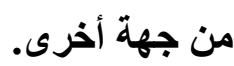

\section{المطاب الثالث}

\section{الفصل بين السلطات لدى نظم حكوهات الجمعية النيابية}

يعد نظام حكومة الجمعية النيابية من أقل النظم السياسية السائده فى الدول، إذ

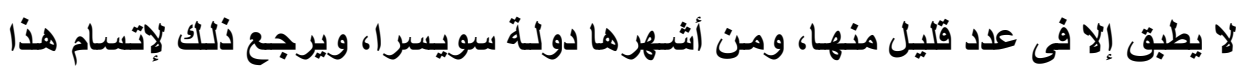
النظام بخصائص قلما وجدت فى نظام سياسى ('). ولكن ما موقف هذا النظام من مبأ الفصل بين السلطات، وهل أختلف التطبيق العملى عن النصوص النظرية، وللإجابة نتناول الأسس النظرية لنظام حكومة الجمعية، ثم التطبيق العملى، وذلك فيما يلى:

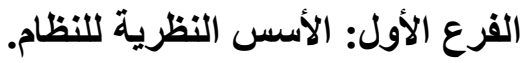
الفرع الثانى: التطبيق العملى للنظام. 


\section{الفرع الأول}

\section{الاسس النظرية للنظام}

قام نظام حكومة الجمعيـة على أسـاس سيطرت سلطة من سلطات الدولة على كافة الامور، إذ اتسم هذا النظام بعدم المساواة بين السلطات، ففى ظل هذا النظام تتمتع السلطة التشريعية بالهيمنة على كافة السلطات الأخرى، إذ أن السلطة التشريعية تحوز سلطة التشريع بالإضافة إلى سلطة تنفيذ القوانين، ولكن نظراً لتعذر مباشرة السلطة التشريعية سلطة تنفيذ القواتين بنفسها، فإنها تعهد بها إلى هيئة خاضعة لها، ومن ثم

فإن السلطة التتفيذية تعد خاضعة للسلطة التشريعية ومنفذه لتعليماتها وتوجيهاتها'(') ويكمن أسـاس ذلك فى إعتبار السلطة التشريعية الهيئة المنتخبة من الشعب انتخابًا مباشراً، ومن ثم فهى المعبره عن آرائه ورغباته، وهذا ما أستتبع هيمنتها على

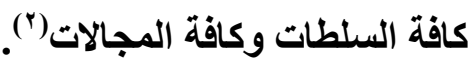
وتجدر الإشارة هنا إلى أن هذه الفكرة تعد إنعكاسـاً لأفكار روسو عن السيادة، والمتمثله فحى ضرورة سيطرة الشعب عليها، ونظراً لصعوبة سبطرة الشعب بصفة مباشرة على كافة السلطات، فإنه يقوم بإنتخاب هيئة نيابية عنه للسيطرة والتعبير عن آرائه ورغباته، هذه السلطة تتمثل فى السلطة التشريعية. وتطبيقًا لذلك هيمن البرلمان ممثل السلطة التثريعية على السلطة التففيذيـة، إذ منح حق اختيار أعضاء السلطة التنفيذيـة، ليس هذا فحسب بـل أنسه يقوم بتوجيههم

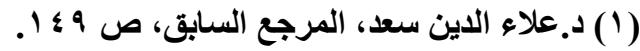

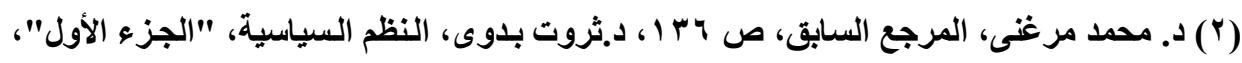

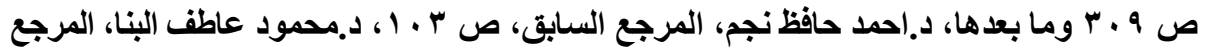


ومراقبة كافة تصرفاتهم من خلال الأسئلة والإستجوابات والأوامر والتعليمـات، بحيث يجب على أعضاء السلطة التنفيذية تنفيذ اوامر وتعليمات البرلمان('). وفى مقابل ذلك لم يكن للسلطة التتفيذية حق حل البرلمـان، ولا الإعتراض على القوانين التى يصدرها البرلمان، وإن كان لأعضاء السلطة التنفيذية حق حضور جلسات البرلمان والإشتراك فى المناقشات وإجراء آرائهم، إلا أنهم لا يشتركون فى التصويت. ليس هذا فحسب بل أن السلطة التنفيذية تلتزم بتقديم تقرير سنوى للبرلمان عن أعمالها، وهى فى ذللك تلتزم بما يبديه البرلمان من ملاحظات عليه، كما لا يحق للسلطة التتفيذية دعوة البرلمان للإنعقاد أو فض الإنعقاد(؟).

ومفـاد مـا سـبق كلـه أن سـيطرة البرلمــان على كافـة السلطات يتضمن إهـاراً صريحاً لمبدأ الفصل بين السلطات، وهذا تطبيقاً لأفكار روسو، حيث أعلى من شـأن السلطة التشريعية المعبره عـن الشعب، وهـا مـا أسـتبع التخلى عـن الفصل بـين

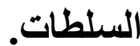

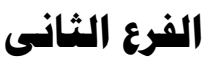

\section{التطبيق العمى لانظام}

تضمن نظام حكومة الجمعية إهداراً لمبدأ الفصل بين السلطات، وذلك تأسيساً على هيمنة البرلمـان ممثل السلطة التشريعية على كافة السلطات، فالسلطة التنفيذيـة خضعت لها خضوعاً تاماً.

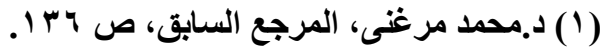

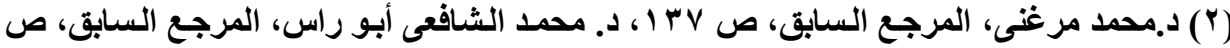


إلا أن الواقع العملى لنظـام جميـة الحكومـة قد عكس اختلافاً عن النصوص

النظرية، إذ ان الواقع شها رجحان سلطان السلطة التنفيذية لا السلطة التشريعية'(1). وقد رجع ذلك إلى أمرين، أولاهمـا أن النظام السويسرى كفل إستقرار كبير للحكومة، إذ ينص الاستور على عدم جواز عزل أعضاء السلطة التنفيذية، فهؤلاء الأعضاء يتم اختيار هم لمدة أربع سنوات، ولا يجوز عزلهم، كما لا يجوز لهم الإستقالة، وهذا ما رتب عدم وجود ما يعرف بالأزمات الوزارية. كما أن العادة قد جرت على إعادة إختيار أعضاء السلطة التنفيذية لمدة أخرى من قبل البرلمان، و هذا ما يستتبع عدم تحديد مدة تولى أعضاء السلطة التنفيذية، ومن ثم فإن الوزراء يتمتعون بنفوذ وسلطان كبير(") وثانيهما أن مدة إنعقاد البرلمان تتسم بالقصر، إذ تتراوح ما بين شهرين وثثلاثة شهور، و هذا ما يتيح للحكومة الإنفراد بالسلطة الددة الباقية التى تمثل الجزء الاكبر من التهن

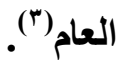

ومفــاد ذلك أن التطبيق العملى قد أختلف عن النصوص، حيث أن السلطة التنفيذية هى التى تسيطر على زمام الامور وليس السلطة التشريعية. ويالرغم من أن التطبيق العملى أختلف عن الأسس النظرية، إلا أن ذلك لم يغير حقيقة أن نظام حكومـة الجمية أهدر مبدأ الفصل بين السلطات، حيث أن هذا النظام

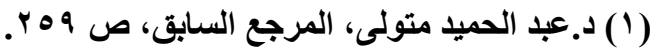

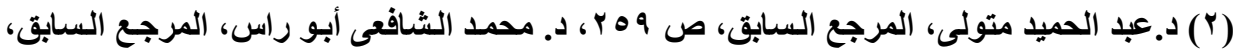
ص الV إن وما بعدها.

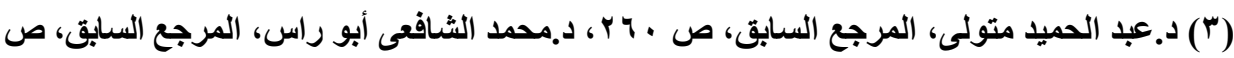

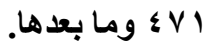


سواء من الناحية النظرية أو العملية لم يعتثق مبدأ الفصل بين السلطات، بل اعلى من شأن سلطة فى مقابل السلطات الاخرى.

وممـا سبق كلـه يتضح أن كلا مـن النظـام البرلمسانى والرئـاسـى قد أعتنقـا مبدأ الفصل بين السلطات سواء بصورته المرنه أو المطلقة، وإن اختلف التطبيق العملى فى كلا منهما عن الاسس النظرية.

ويرجع ذلك الإعتناق إلى الإيمان بأفكار لوك و مونتسكيه عن مبدأ الفصل بين السلطات، وإعتباره أحد ضمانات حريات الأفراد ومنع الطغيان والإستبداد. وفى مقابل ذلك فإن نظام حكومة الجمعية قد أهدرت فكرة الفصل بين السلطات، وذلك تأسيساً على أفكار روسو عن السيادة، وإن السيادة يجب أن تكون للشعب، ولا يمكن التنازل عنها أو تجزئتها. 


\section{المبحث الثانى \\ تطبيق الأساس الفلسفى للفصل بين السلطات فى هصر}

شهدت مصر على مر العصور العديد من النصوص الاستورية التى تحدد شكل

الدولـة ونظامهـا، ومـن ضـن هذه الانظمـة الاخذ بمبـأ الفصل بين السلطات وكيفيـة

$$
\text { تطبيقه. }
$$

وقــ شـهـ المجتمـع المـصرى العديـد مسن التطـورات السياسية والاجتمـاعيـة والاقتصادية، وهذا ما استتبع إصدار دستور جديد ليواكب هذه الاحداث.

كما ثار الخلاف فى الآونـة الأخيرة حول دور المحكمـة الاستورية العليـا، وهل يعد دورها إنتهاكاً لإختصاصات السلطة التشريعية.

وبنـاءً على ذلك نتــاول العلاقة بين سلطات الدولة فى ظل الدسـتير المختلفة

لمصر، وذلك فى سبيل توضيح كيفية تطبيق مبدأ الفصل بين السلطات، ثم دور المحكمة الاستورية لبيان دورها فى ضوء مبدأ الفصل بين السلطات، وهل يعد ذلك تدخل فى شئون اختصاصات السلطة التشريعية، وذلك فيما يلى: المطلب الأول: العلاقة بين سلطات الدولة.

المطلب الثـانى: دور المحكــة الدسـتورية العليـا فـى ضـوع مبـدأ الفـصل بـين السلطات. 


\section{المطاب الأول}

\section{العلاقة بين سلطات الدولة}

مـرت مـصر بالعديــ مـن المراحل على مـر عصورها، فمن حكم ملكى إلى هـ

جمهورى، ومن نظام برلمانى إلى رئاسى، وهذا ما استتبع بلورة النصوص الاستورية

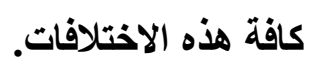

إلا أن ذلك لم يؤثر فى إعتناق كافة الاساتير المصرية مبدأ الفصل بين السلطات،

$$
\text { وذلك فى صورته المرنه، وهذا ما أكده الاستور الجديد. }
$$

ويناءً على ذلك نتناول الدساتير المصرية المختلفة بثأن موقفها من مبدأ الفصل بين السلطات، ثم موقف الدستور الجديد من هذا المبدأ، وذلك فيما يلى: الفرع الأول: موقف الدساتير المصرية من مبدأ الفصل بين السلطات. الفرع الثانى: موقف الدستور الجديد من مبأ الفصل بين السلطات.

\section{الفرع الأول}

\section{هوقف الدساتيز المصرية هن هبدأ الفمل بين السلطات.}

أكدت كافة الاساتير المصرية السابقة على أعتنقها مبدأ الفصل بين السلطات،

وذلك بالرغم من التباين فيما بينها فى طبيعة الحكم والأوضساع السياسية والاقتصادية والاجتماعية السائده، ويمكن تفصيل ذلك فيما يلى : بائر

* مقتبس من رسالتنا للاكتور اه، ص V ₹ ؛ وما بعدها. 


\section{"أولاً: دستور rarr:}

أخذ دستور بr 9 r بمبدأ الفصل بين السلطات إلا أن هذا الفصل لم يكن جامداً بل أوجد نوعاً من الرقابة والتعاون بين السلطتين التشريعية والتفيذية، بحيث عكس توافر الركن الثانى من أركان النظام البرلمانى.

فبالنسبة للتعاون فقد ظهر فى مجال التشريع حيث اشتركت السلطة التنفيذية مع السلطة التشريعية فى تثريع القوانين، فقد أقر الاستورحقها فى القوانين(')، وحقها فى التصديق على القوانين بحيث لا يصدر القانون إلا بتصديق السلطة التنفيذية عليه(؟)، هذا بالإضافة لحق الملك ممثل السلطة التففيذية بإصدار القوانين(") .

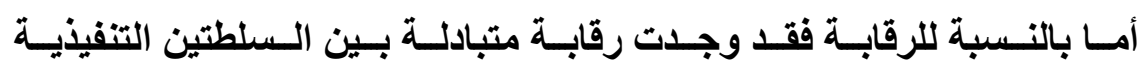
والتشريعية، فمن جهة رقابة السلطة التشريعية فقد تمثلت فى حق البرلمـان باعتباره السلطة التشريعية فيما يأتي (؛):

- هـق السسؤال: وهو عبـارة عن حق الأعضاء فـى توجيه الأسـئلة للـوزراء

$$
\text { لاستيضاح أمر معين فى أعمال الوزارات. }
$$

r - حق الاستجماب: وهو أكبر من السؤال، حيث يهذف العضو منـه انتقاد سياسـة

الوزارة.

$$
\begin{aligned}
& \text { (1) المادة ^ ^ من الاستور. }
\end{aligned}
$$

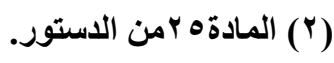

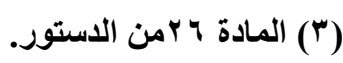

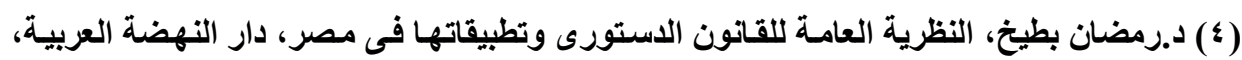

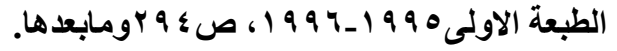

V مجل مجلت البحوث القانونيت والإقتصاديت 
r - التحقيق البرلمانى: وهو تحقيق تقوم به لجنة دائمـة أو خاصـة تابعة للبرلمـان

لتقصى الحقائق حول مسألة معينة.

\section{ع - المسئولية الهزارية:}

وهـى أهـم وأخطر وسـيلة مسن وسـائل الرقابـة، حيث قرر الاسـتور مسئولية

الوزراء التضامنية عن السياسة العامـة للوزارة من جانب، ومن جاتب آخر مسئولية الوزراء الفردية كل فى وزارته وذلك أمام البرلمـان، وهذه المسئولية مقررة فقط أمسام

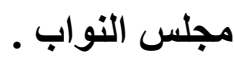
وتجدر الإثـارة إلى أن هذا الحق ولخطورته قد أحيط بضمانات عديدة للحد من سوء استخدامه، حيث منح الوزراء حق طلب مهلة ثمانية أيام قبل الاقتراع على طرح الثقة، هذا بالإضافة إلى أن التصويت فى حالـة طرح الثقة يكون بالمناداة على الأعضاء بالاسم وبصوت عال مما يوفر العلانية التى تنهى أى شك فى المؤمرات الخفية، إلا أن

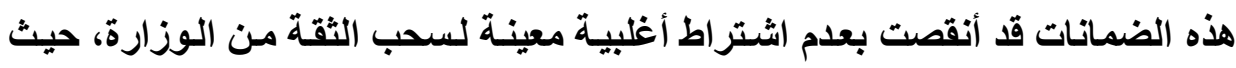
اكتفى بالأغلبية المطلقة لعدد الأعضاء الحاضرين وهو مايعد انتقاصـاً من الضمانات الواجب توافرها.

أما من جهة رقابة السلطة التنفيذية على السلطة التشريعية فقد تمثلت فى (')

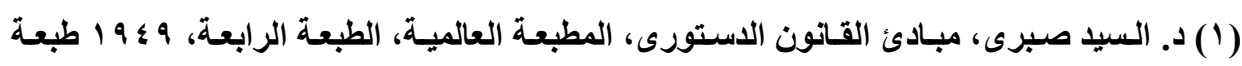

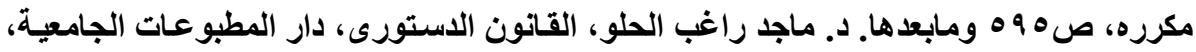

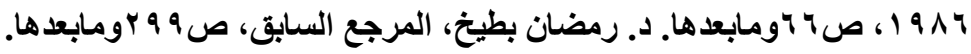


ا ـ التـدخل فـى تكـوين وانعقـاد البرلمــان، حيـث تشرف السلطة التنفيذيـة على الاتتخابـات البرلمانيـة وتعلن نتيجتهـا، هذا بجانب حقهـا في دعوة البرلمــان للانعقاد وفضه فى الأدوار العادية وغير العادية. r - حق حل مجلس النواب: فقد منحت السلطة التنفيذيـة حق حل مجلس النواب وذلك فى مقابل حق مجلس النواب فى سحب الثقة من الوزارة، والحل يـأتى من الملك ويسمى الحل الملكى أو الرئاسى، والملك يلجبأ لذلك فى عدة أحوال منها قيام نزاع بينه وبين الوزارة والبرلمان، أو الاعتقاد لتغير الظروف بأن البرلمان أصبع لا يمثل الأمة. r- وقد أحيط هذا الحق بعدة ضمانات نظراً لخطورته منها، أنه لايجوز حل المجلس مرتين لذات السبب، ويرجع ذلك إلى أن الحل كان بمثابة أخذ رأى هيئة الناخبين فى أمر معين وليس هناك أى سبب أو مبرر لأخذ رأى هيئة الناخبين مرة أخرى بعد أن أبلات رأيها فيه. هذا بالإضـافة لضمانة ضرورة تضمين أمر الحل أمراً بدعوة النـاخبين لإجراء انتخابات جديدة فى ميعاد قريب لا يتجاوز الشهرين، وبجاتب هذا فقد حرمت السلطة التنفيذية من القيام بأعمـال ذات خطورة خاصـة

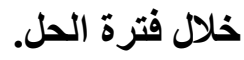
ثانيا: دلستور 1907 : أعتنق دستور 1 ه نظاماً برلمانياً، ومن المعروف أن النظام البرلمانى يقوم على توافر عنصرين أولهما ثنائية الجهاز التففيذى وثثاتيهما التعاون والرقابة المتبادلة بين السلطتين التشريعية والتنفيذيـة، ولـم ينص الدستور على هذين العنصرين بـل أغفل 
عنصر الثنائية بينما نص على التعاون والرقابة بين السلطتين التنفيذية والتشريعية، فاللستور لم يقرر النظام البرلمانى بصورة كاملة.

ويتضح عنصر التعاون والرقابة فيما قرره الاستور من نصوص، فمن جهة فإن التعاون يظهر فى المجال التشريعى، حيث منح الدستور للسلطة التنفيذية حق اقتراح القوانين والاعتر اض على المشروعات التى يقرها مجلس الأمسة، هذا بالإضافة لحق

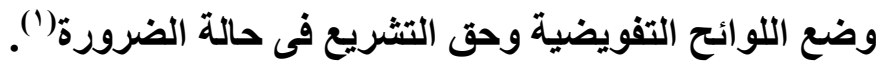
أما من جهة الرقابة بين السلطتين فقد أوجد الاستور رقابة متبادلة، فبالنسبة لرقابـة السلطة التشريعية على التنفيذيـة قرر الدستور حقى مجلس الأمسة فى سؤال الوزراء و استجو ابهم، كما استقر الفقه على حق المجلس فى اجراء تحقيق برلمسانى، هذا بجانب حقه فى طرح موضوع عام للمناقشة، وتقرير المسئولية الفردية للوزراء أمام المجلس، كما تقرر حق المجلس فى اتهام رئيس الجمهورية جنائياً وذلك في حالية

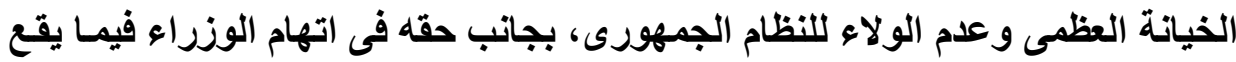

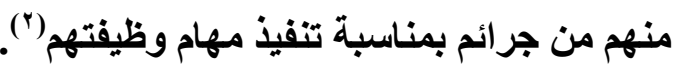
ويلاحظ أن مسئولية الـوزراء إنمسا هـ مسئولية فرديـة فقط أمسا المسئولية التضامنية فلا محل لها، ويرجع ذلك لقيام رئيس الجمهورية بنفسه بوضع السياسة

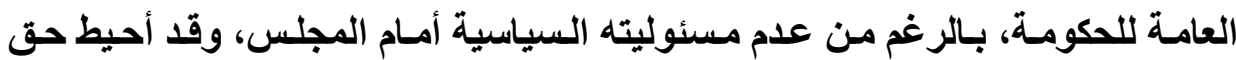

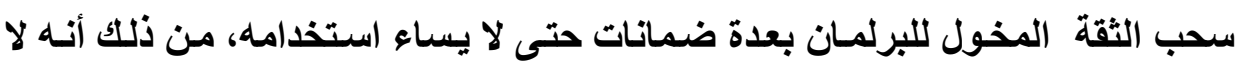

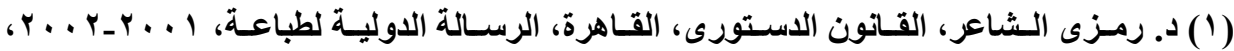

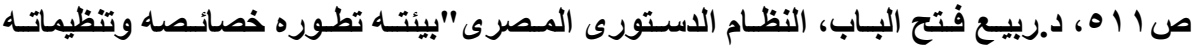

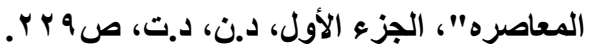

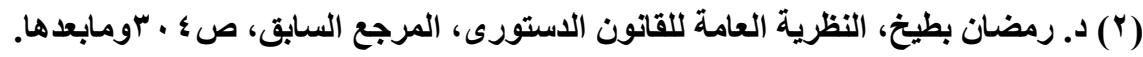




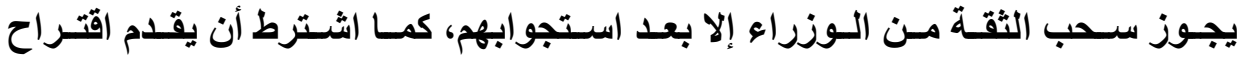
ســب الثقــة مـن عـشر أعـضاء المجلـس علـى الأقـل، وأن يــدر القـرار بأغلبيـة

أما بالنسبة لرقابة السلطة التنفيذية على التشريعية، فقد منح الاستور للسلطة التنفيذية حق دعوة مجلس الأمة للانعقاد العادى أو غير العادى، وذلك فى عدة حالات منها الضرورة وطلب أغلبية أعضاء مجلس الامة وإعلان حالة الطوارئ، كمـا لها حقى فض الدورات، هذا بجانب الوسيلة الأهم وهى حق الحل، حيث أعطى الدستور لرئيس الجمهورية حق حل مجلس الأمة وذلك فى حالـة نشوب خلاف بينه وبين المجلس، أو اعتقاده أن المجلس لم يعد يمثل الأمة، وقد أحيط هذا الحق بعدة ضمانات منها عدم حل المجلس لذات السبب مرتين، وضرورة أن يتضمن قرار الحل دعوة النـاخبين لإجراء

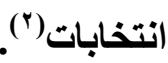

ومما سبق يتضح أن دستور $ه$ ه أعتنق مبدأ الفصل بين السلطات فى صورته المرنة.

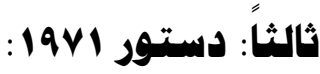

تضمن الاستور أركان النظام البرلمـانى من ثنائية الجهاز التنفيذى والتعـاون

والرقابة بين السلطتين التشريعية والتفيذية.

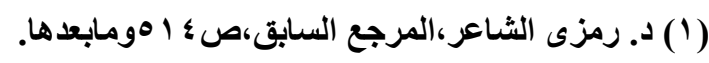

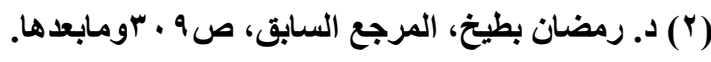

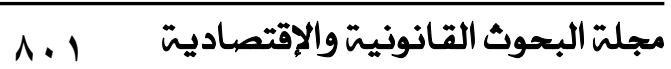


فمن جهة ثنائية الجهاز التنفيذى فقد أقر دستور 19V1 هذا المبدأ ـوذلك عكس مـا كـان مقرراً فـى دستور 1901 1-، حيث فصل بين شخص رئيس الدولـة وشخص رئيس الوزراء ، آخذاً بمجلس الوزراء ومنحه اختصاصات فعلية'(1). ومن جهة التعاون والرقابة بين السلطتين التشريعية والتفيذيـة، فقد أقر الدستور الأمرين فبالنسبة للرقابة بين السلطتين، قرر الدستور للسلطة التشريعية على

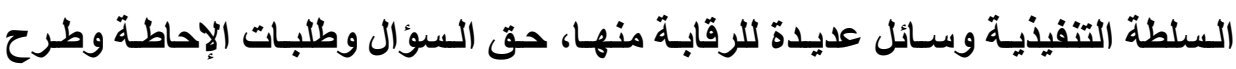
موضوع عام للمناقثة، وإجراء تحقيق مع أعضاء السلطة التنفيذية، حق الاستجواب، هذا بجانب تقرير المسئولية الفردية والتضامنية للوزراء أمام مجلس الثعب("). وتجدر الإشارة إلى أن المسئولية التضامنية قد عادت من جديد للتطبيق، لإقرار الدستور وجود مجلس للوزراء، وذلك عكس دستور 1904 الذى لم يوجد بـه مجلس

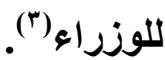
وبالمقابل فقد منحت السلطة التنفيذية ممثلة فى شخص رئيس الجمهورية حق دعوة البرلمان للانعقاد العادى أو غير العادى())، هذا بجانب حق حل البرلمان فى حالية

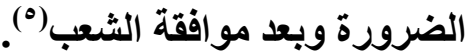
أما من جهة التعاون فقد منحت السلطة التتفيذية حق اقتراح القوانين واصدارها

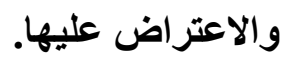

$$
\text { (1) د. دمزى الثاعر،المرجع السابق،ص • بT". }
$$

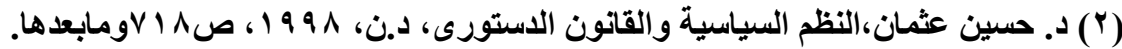

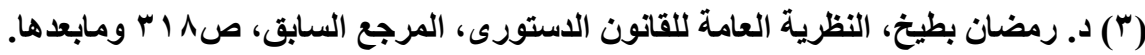

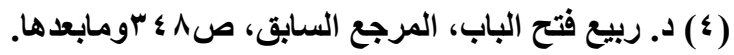

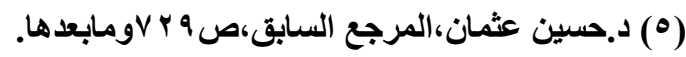


ويتضح من ذلك إعتناق الاستور مبأ الفصل بين السلطات فى صورته المرنـه،

بل بصورة تقترب من أفكار مونتسكيه عن المبدأ عن أى دستور سابق"('".

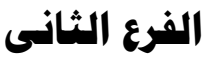

\section{هوقف الدستور الجديد r r r هن هبدأ الفصل بين الساطات}

شهر المجتمع المصرى العديد من التطورات فى الأونة الاخيرة، من قيام ثورتين أدت إلى تغيير فى أنظمة الدولة، وهذا مـا أستتبع صدور دستور جديد يتوائم مـع هذه

$$
\text { التطورات الحديثة. }
$$

وقــ نـص الاستور الجديد صـراحة على إعتنـاق مبـدأ الفصل بـين السلطات

وبصورته المرنة، فقد تضمنت المـادة "ף " منـه على أن "النظام السياسى يقوم على إلى مبـادئ الايمقراطيـة والشورى، والمواطنـة والتعدديـة السياسية والحزبيـة، والتـداول السلمى للسلطة، والفصل بـين السلطات والتـوازن بينهـا"، وهـا مـا أكده التعـيل الاستورى فى ع ا ب أيضاً فى مادته الخامسة.

فالاسـتور بنـاءُ على هذا النص قد أعلن صـراحة إعتناقـه مبـدأ الفصل بـين السلطات، وهو لـم يقف عند ذلتك الأمر بل أوضـح إعتناقه المبدأ فى صورته المرنـة القائمة على التوازن بين السلطات.

وتطبيقًا لهذا النص تتضمنت أحكام الاستور تنظيم الثلاث سلطات من تشريعية وتنفيذية وقضائية بصوره تحقق هذا المبدأ، إذ وزعت هذه السلطات على ثُلاث هيئات مختلفة، كما تمتعت كل منها بإستقلال عن الاخرى.

(1) رسالتنا للاكتوراه المرجع السابق، صبV \& وما بعدها

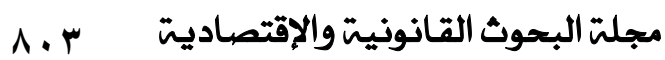


فمن جهة السلطة التشريعية فقد منحت سلطة التشريع والرقابة على أعمال

السلطة التنفيذية، وذلك بواسطة مجلس النواب(')

وقد تتضمن الدستور تشكيلها من مجلسين هـا النواب والشورى(")، وتجدر

الإثدارة إلى أن تعديل الاستور قد قصر السلطة التشريعية على مجلس النواب فقط"(")،

وقد منح أعضاء الهيئة التشريعية حق إبداء رغبة لرئيس الوزراء أو أحد الوزراء

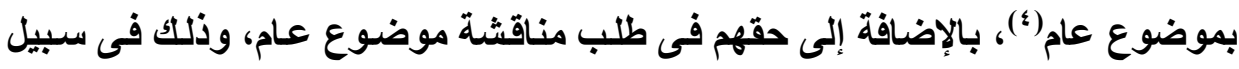
تبين سياسة الحكومة بصدده(ْ)

وتحقيقاً لإعمال الرقابة على السلطة التنفيذية، فقد قرر الاستور حق أعضاء

مجلس النواب فى توجيه الأسئلة لأعضاء الحكومـة كافة، وذلك فى أى موضوع يلخل ضمن إختصاصاتهم، وقد أوجب الاستور على الحكومة الرد على هذه الأسئلة'("). كما منح أعضاء مجلس النواب حق تقديم طلب إحاطة أو بيانـاً عاجلاً لأعضاء

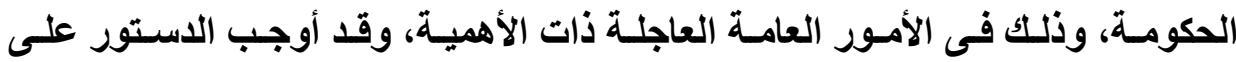

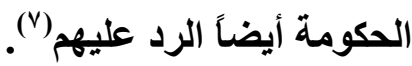

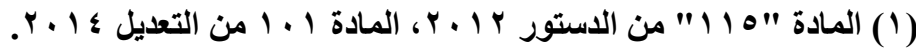

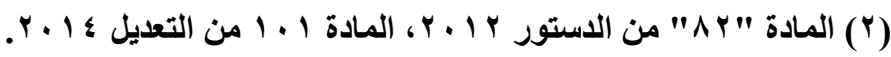

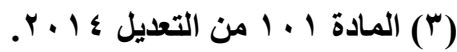

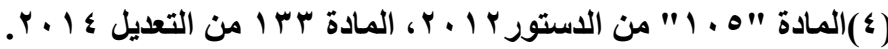

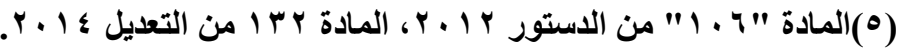

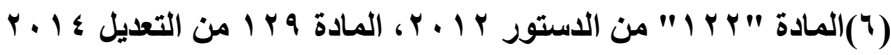

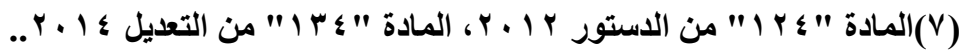

مجلتّ البحوث القانونيت والإقتصاديت 
هذا بالإضافة إلى حق أعضاء مجلس النواب فى توجيه أستجوابات لأعضاء الحكومة، وذلك فى سبيل مساءلتهم عن الثئون التى تلخل ضمن أختصاصاتهم (')، وقد عد الإستجواب ضرورة إلى ما هو أبعد ألا وهو سحب الثقة. فقد نص الاستور على أنه يجوز لمجلس النواب تقرير سحب الثقة من رئيس الوزراء أو احد نوابه أو أحد الوزراء، إلا أن ذلك لا يجوز إلا بعد استجواب("). كمــا أن الاســتور قـــ مـنـح مجلـس النـواب حـق تـشكيل لجــان خاصـة أو تكليف أحد لجانـه بفحص إحدى الجهات الإداريـة أو الهيئـات، وذلك من أجل تقصى

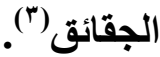
أمسا مـن جهـة السلطة التنفيذيـة فقـــــرر الاسـتور رئاسـتها لـرئيس الدولـة، وهـو

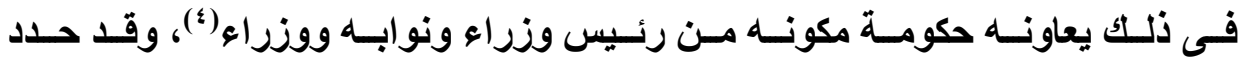
الاستور مهام الرئيس ومن ضمنها مراعاة مصالح الشعب، والحدود بين السلطات،

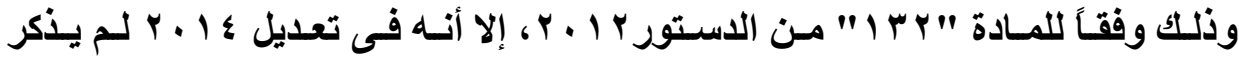
الحدود بين السلطات، إكتفـاءَ بذكر الإلتزام بأحكام الاستور التى تضمنت الفصل بين

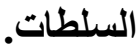

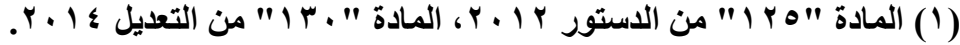

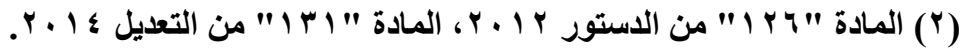

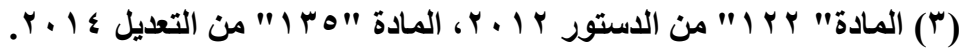

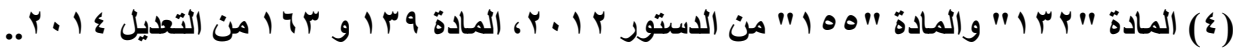
مجلت البحوث القانونيت والإقتصاديت 
وقد منحت السلطة التفيذية حق دعوة السلطة التشريعية بمجلسيها للإنعقاد،

وذلكك فى دورات الإنعقاد العادية أو غير العادية، وذلك من خلال رئيس الدولة'(')

كمـا مـنح أعضاء الحكومـة من رئيس وزراء ونوابـه والوزراء ونـوابهم حق

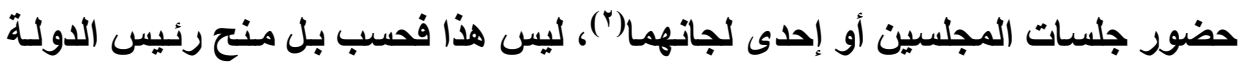
والحكومة حق إقتراح القوانين(")

هذا بالإضافة إلى حق رئيس السلطة التنفيذية "رئيس الدولة" فى حل مجلس

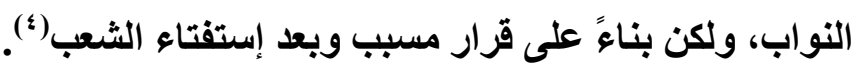
أما من جهة السلطة القضائية فقد قرر الاستور إعتبارهـا سلطة مستقلة تقوم بتطبيق القانون وتحقيق العدالة(ه) ومفاد ما سبق كله أن دستور مصر r ا ب ب بتعديله قـ أعتنق مبدأ الفصل بين السلطات، وذلك فى صورته المرنه والتى تقترب من أفكار لوك و مونتسكيه. حيث أوجد نوعاً من التعاون والرقابة فيما بين السلطات، فمن جهة التعاون منح أعضاء الحكومة ممثلى السلطة التنفيذية حثى حضور جلسات السلطة التشريعية ممثلـه فى البرلمسان، هذا فى مقابل حق البرلمسان فى طلب المعلومسات من السلطة التنفيذية كوسيلة لتقصى الحقائق.

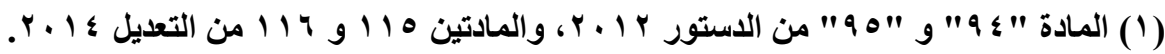

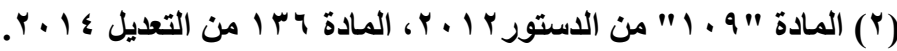

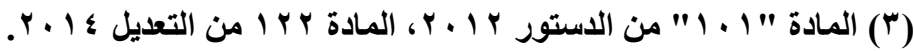

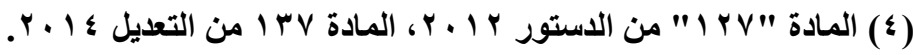

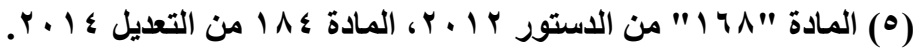


أما من جهة الرقابة، فقد منحت السلطة التشريعية العديد من الحقوق تطبيقًا لذلك، مـن أهمها حق توجيه الأسئلة و طلبـات الإحاطة، و حق الإسـتجواب لأعضاء السلطة التنفيذية، ليس هذا فحسب بل إن السلطة التشريعية ممثله فى مجلس النواب له حق سحب الثقة من رئيس الوزراء أو أحد الوزراء. وتجدر الإشـارة هنـا إلى أن تعديل ـ ا ب r منع السلطة التشريعية حق سـب الثقة من رئيس الجمهورية ذاته، وذلك بضوابط حددت بطلب مسبب موقع من أغلبية الأعضاء، هذا بالإضافة لضرورة موافقة ثلثى أعضاء المجلس، وذلك قبل أن يعرض من من على الشعب لإستفتائه(')

وهذا الأمر يعد أمراً جديداً لم تعرفه الاساتير المصرية من قبل، فمن المتعارف عليه هو حق السلطة التشريعية فى سحب الثقة من الوزراء، أمسا أن تسحب الثقة من

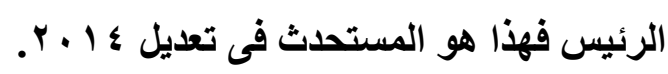
وفى مقابل ذلك منحت السلطة التفيذية حق إقتراح القوانينوهذا مخالفة لأفكار مونتسكيه- وحق دعوة البرلمان للإنعقاد، بالإضافة إلى حق السلطة التتفيذية ممثله فى رئيس الدولة فى حل البرلمان. ومما سبق يتضح أن الاستور أقر مبدأ التعاون والرقابة بين السلطات، وهذا مـا يعكس إعتناقـه مبـدأ الفصل بـين السلطات فى صـورته المرنـه، وذلك على مستوى النصوص. 
وتجدر الإثــارة هــا إلى أن اللستور قـ أعطى للـرئيس حق اختيـار رئسيس

وزرائه، وإن وضع فرض حال عدم إكتسابه ثقة البرلمسان ممثل فى مجلس النواب، إذ إذ إذائ قرر تكليف الرئيس لرئيس وزراء من الحزب الحائز على أكثرية برلمانية(')

وهذا الامر هو ما قد يخل بمبدأ الفصل بين السلطات من الناحية العملية، إذ قد ينثأ رجحان كفة السلطة التنفيذية ممثلة فى الحكومة على السلطة التثريعية، وذلك لما قد تمثله قوة الحزب من سند للحكومة يصعب معها مساعلتها، وهذا ما أتضح من خلال التطبيق العملى لهذا الأمر فى النظام الإنجليزىكما سبق الذكر-.

\section{المطاب الثانى}

دور المكمة الدستورية العليا فى ضوء هبدأ الفصل بين السلطات

ثار الجل مؤخراً حول دور المحكمة الدستورية العليا فى الرقابة على دستورية القوانين، ومدى اعتبار ذلك تدخل من السلطة القضائية فى أعمال السلطة التشريعية، وهذا ما يعد إفتتات على مبدأ الفصل بين السلطات الذى أقره الاستور الجديد. وقد ألقى الجدل الضوء على جدل قديم فى الفقه والقضاء حول مدى الأخذ بالرقابة على دستورية القو انين.

ويناءً على ذلك نتناول الخلاف الذى ثار فى الفقه حول مدى الاخذ بالرقابة على

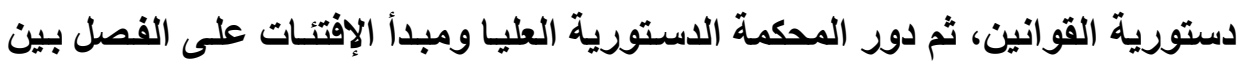

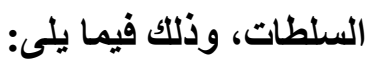
الفرع الأول: الخلاف حول الاخذ بالرقابة الاستورية. الفرع الثانى: الرقابة على دستورية القو انين ومبدأ الفصل بين السلطات. 


\section{الفرع الأول \\ الخلاف حول الأخذ بالرقابة الدستورية}

أتسم موقف الدساتير المصرية قبل دستور 19 أبالسلبية فيما يخص الرقابة

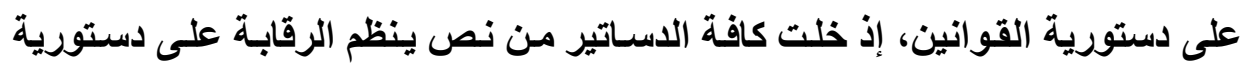

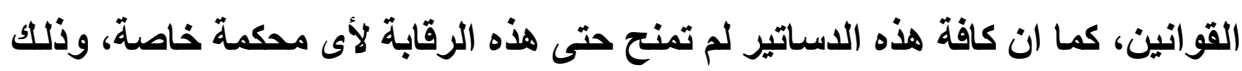

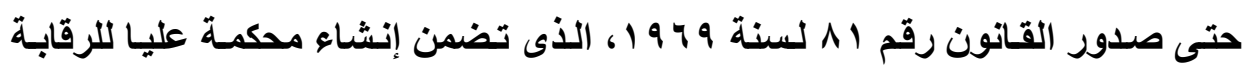
على دستورية القوانين(')

هذا السكوت من قبل الدساتير المختلفة قد أثثار الجدل فبينمـا أتجه فريق لرفض

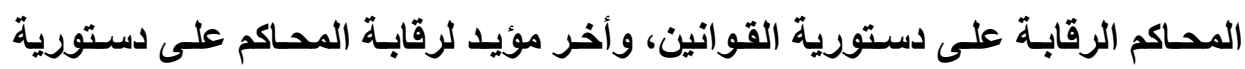

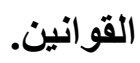

أما من جهة الفريق الرافض لرقابة المحاكم على دستورية القوانين، فقد أستتـ

$$
\text { على الرفض على عدة حجج تمثلت فى (ن) }
$$

أولاً: أن المادة "ه إ" من لانحة ترتيب المحاكم الوطنية و التى تقابلها المسادة

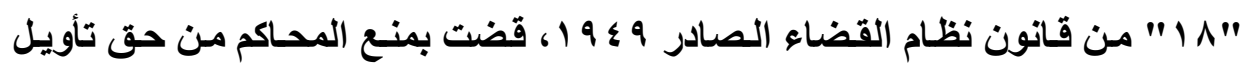

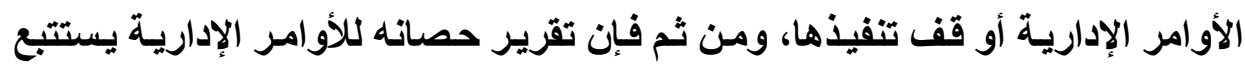
سريانها على القوانين من باب أولى.

(1) د. نبيله عبد الحليم، الرقابة على دستورية القوانين "القضاء الاستورى"، دار النهضة العربية، (T)

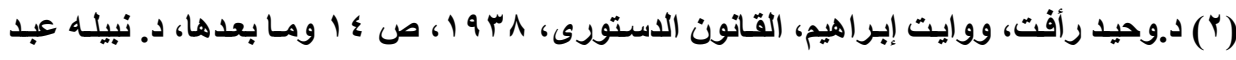

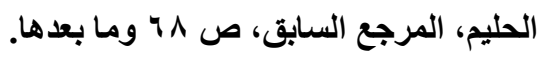

مجلم البحوث القانونيت والإقتصاديتة 
ثانيـاً: أن القضاء الفرنسى يساتده بعض الفقهـ(')ـولمـا لـه مسن نـأثير على القضاء المصرى-قد أقر عدم جواز رقابة المحاكم على دستورية القوانين، ويرجع هذا الموقف من الرفض إلى أسباب تاريخية وسياسية وقانونية. أما من الناحية التاريخية فقد شهدت فرنسا نوعاً من المحاكم التى كانت تسمى

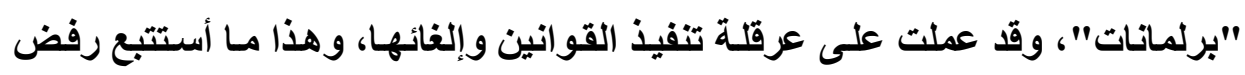
الرقابة من قبل المحاكم، وقد وجدت العديد من النصوص فى القوانين القرنسية التى ترفض رقابة المحاكم صراحة. أما من الناحية السياسية فقد أستتد فقهاء هذا الرأى إلى رأى روسو بأن القانون هو مظهر لإرادة الامة التى تسيطر على زمام الامور، لذا لا يمكن أن يكون عليها رقيب سوى ضمير أعضائها وممثليها.

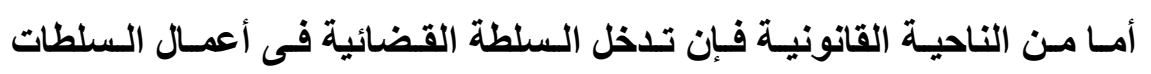
الاخرى، كالسلطة التشريعية مثلاً أو التنفيذية وتعطيل قرارتهما لهو إهداراً لمبدأ الفصل بين السلطات.

ثالثاً: أن القضاه فى مصر يخضعون للسلطة التففيذية، وذلك من خلال قيام

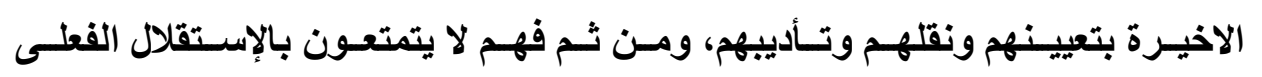
والضرورى للقيام بهذه المهمة الدقيقة(؟).

(1) Carre de malberg: contribution a le theoriegenerale de l etat, 1920, T1, p.747, et $\mathrm{T} 2, \mathrm{p.50}$ et .s.

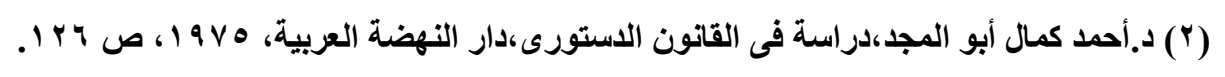

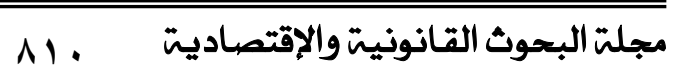


أما من جهة الفريق المؤيد لرقابة المحاكم على دستورية القوانين(')، فقد رأى أن خير الوسائل لممارسة الرقابة على دستورية القو انين هى قيام الححاكم بهاب(")، وذلك الك الكائ

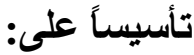

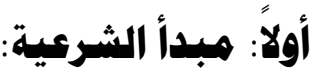

إذ أن الدول فى قيامها بعملها من خلال السلطات التشريعية والتففيذية تصدر

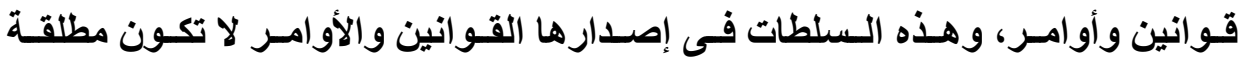
السلطات، و إنما هى مقيده بحدود مرسومة لها، وذلك من قبل الاستور. وتتسم الحكومات أو الدول بقانونيتها من عدمه على أسساس خضوع الكافة من حكام ممثلين فى رئيس الدولة والوزراء والبرلمان والمحكومين للقانون، وهذا مـا يمثل

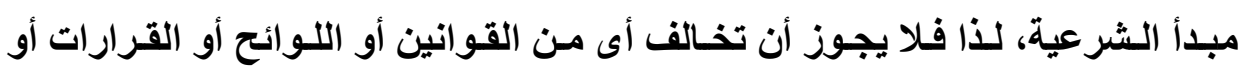

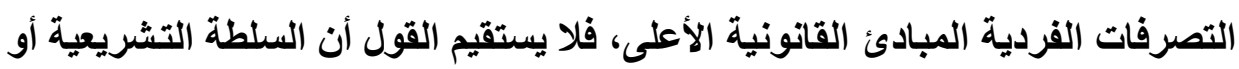
التنفيذية لا رقيب عليهما سوى ضمير أعضائها ومسئوليتهم أمام الامة.

فالحكومة لا يمكن أن تتصف بالثرعية إلا إذا أتفقت تصرفاتها ميع القانون، أمسا

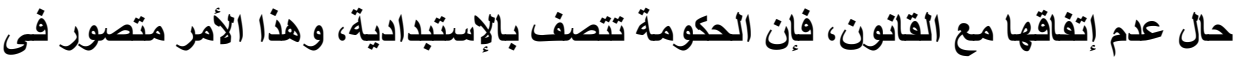
كافة الحكومات الإستبدادية والايمقراطية ذات البرلمانـات المنتخبة(")، لذا وجب التاكد

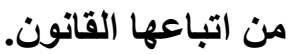

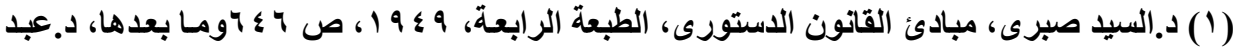

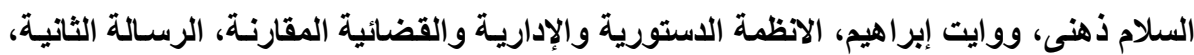

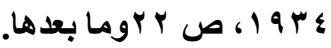

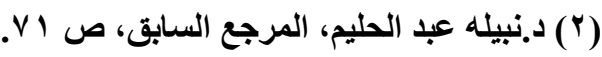

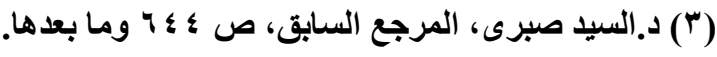

مجلتم البحوث القانونيت والإقتصاديت 


\section{ثانيا: طبيسعة عمل القاضى:}

إن إسناد الرقابة على دستورية القوانين للمحاكم مناطه أن وظيفة القاضى تتمثل فى تطبيق القانون، فهو مقيد فى عمله بـالقوانين ومن بـاب أولى بالاستور الذى هو أعلى من كافة القوانين.

وتطبيقًا لذلك فِان القاضس ملزم بتطبيق القانون الأعلى وترك القانون الأدنى المخالف، وذلك سواء أكان المعروض عليه خلاف بين قانون ولايحه، أو من بـاب أولى

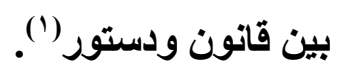

وتجدر الإثـارة إلى أن القاضسى فى ذلك لا يخرج عن نطاق عمله،فهو لا يلغى قانون وإنما يطبق قانون أعلى، ومن ثم فإن إمتناع السلطة القضائبة عن تطبيق قانون

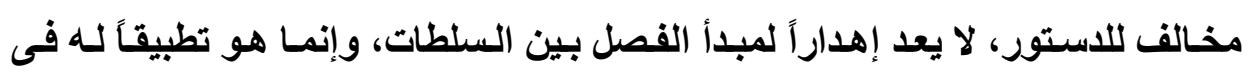
تفسيره السليم. وتفصيل ذلك أن كل من السلطتين التشريعية والقضائية مستقلتين، وتقوم كل منها بأعمالها فى ضوء الاستور، فبإذا مـا قامـت السلطة التشريعية بمخالفة القواعد الأعلى ألاوهى الاستور، فإن ذلك لا يمثل إجباراً على السلطات الأخرى ومنها السلطة القضائية لإنتهاج ذات النهج فى الإعتداء، والقول بغير ذلك من أن السلطة القضائية تقف موقف المشاهد ولا تتحرك ساكناً ضد هذا الإعتداء، يستتبع القول بخضوع السلطة القضائية للسلطة التشريعية، وهذا ما يخالف مبدأ الفصل بين السلطات(؟). 
وبغض النظر عن هذا الخـلاف فى ذاته، فإن من الاهمية تركيز الإهتمسام على

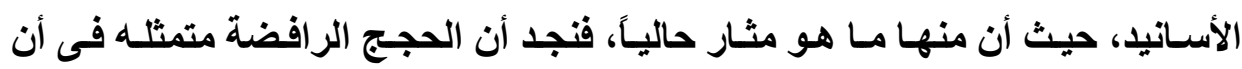
الرقابة تعد إهداراً للفصل بين السلطات، وإن القضاه خاضعين للسلطة التنفيذيـة، وإن السلطة التشريعية تمثل تعبيراً عن الإرادة الأعلى وهى إرادة الشعب، فلا يجوز إعمال الرقابة عليها، قد ظهرت مجدداً.

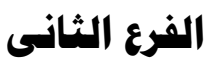

\section{الرقابة على دستورية القوانين وهبدأ الفصل بين السلطات}

تم تاكيـ وجـود المحكمة الدستورية العليـا بموجب النص عليهـا في دستور

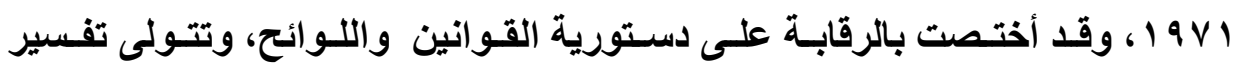

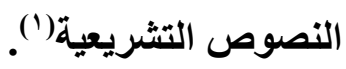

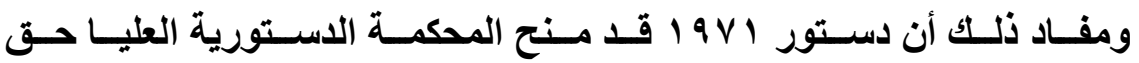
رقابـة دستورية القوانين واللـوائح، وقد تمثلت هذه الرقابـة فـى رقابـة لاحقـة على القوانين، إذ كان يشترط لتفعيل رقابة المحكمة أن يكون هنايك قانون أو لائحه قد صدرت

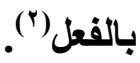

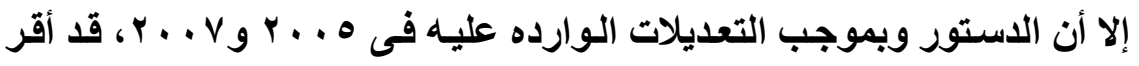

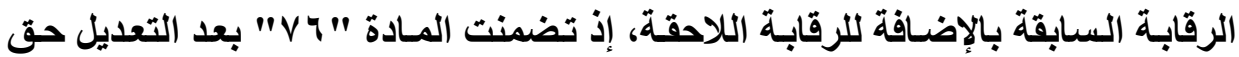
رئيس الاولـة فى عرض مشروع القـانون المنظم للإنتخابـات الرئـاسية على المحكمـة 
الدستورية العليا بعد إقراره من مجلس الشعب وقبل إصداره لتقرير مدى مطابقته للاستور.

ومفاد ذلك أن دستور 19 ا قد أقر على سبيل الإستثناء الرقابة السابقة على

دستورية القوانين، وذلك فيما يخص القانون المنظم للإنتخابات الرئاسية فقط. وقد وجلت العديد من الاسس التى دعت هذا التعديل، من ضمنها أن هذا النوع

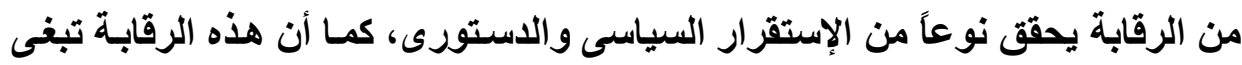
إصدار القوانين والتشريعات بعد أن تكون أستكملت الدراسـة والبنيـان، وذلكت بفعل

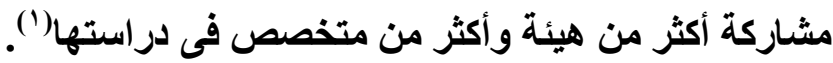

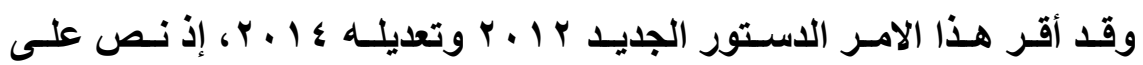

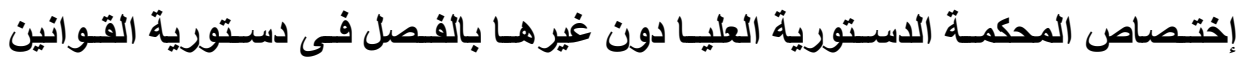
واللوائح(")، وهذا ما يمثل الرقابة اللاحقة على دستورية القوانين. كما أنه أقر الرقابة السابقة وذلك بتضمنه نص يلزم كل من رئيس الدولية و مجلس النـواب بعرض مسروعات القـوانين المنظــة لمباشـرة الحقـوق السياسية،

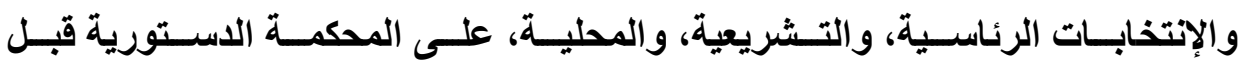

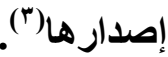

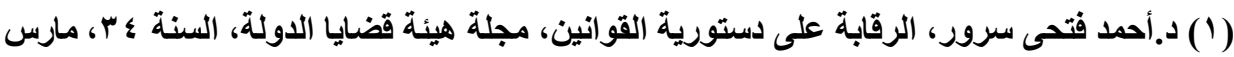

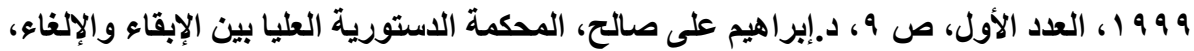

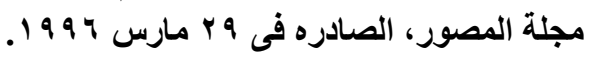

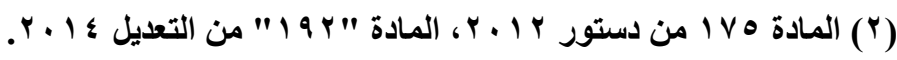

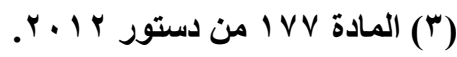


وقد يرجع هذا الامر إلى تعرض الدولة لبطلان الإنتخابـات التشريعية لمجلس

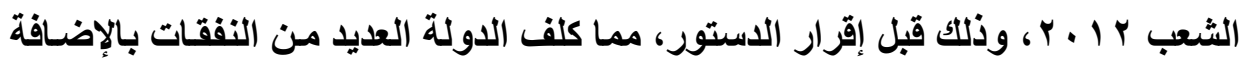
لما خلفه من فراغ سياسى وتشريعى لفترة ما. إلا أن الخلاف قد ثار مجدداً حول مدى ضرورة عرض النصوص التى قررت المحكمة الاستورية العليا إنها مخالفة للاستور على المحكمة من جديد بعد تعديلها من

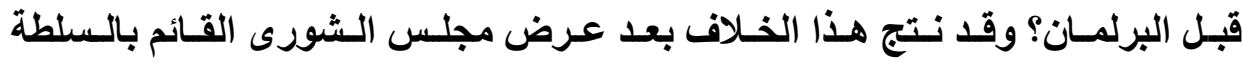
التشريعية مؤقتاً فى غياب مجلس النواب، لقانون الإتتخابـات التشريعية على المحكمة الاستورية العليا، ورفضها بعض نصوص هذا القانون.

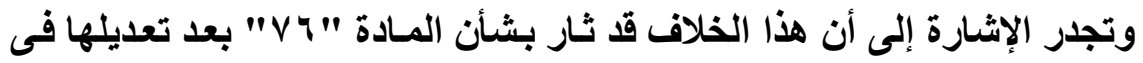
دستور 19V1، حيث أغقلت هذه المادة كما هو الدستور الجديد هذا الفرض.

وفى ظل المادة " " " ذهب جاتب إلى وجوب إعـادة هذه النصوص للمحكمة الاستورية العليا قبل صدورها، وذلك على أساس أن الدستور قد جعل من هذه الرقابـة وجوبية، لذا وجب تطبيقاً لها عرض النصوص الجديدة على المحكمة الدستورية العليا، حيث أن إصدارها بدون عرضها على المحكمة الدستورية العليا ثانية يحصنها، وهذا ما يستتبع قيام المحكمة بالحكم بعدم قبولها الطعن حسل قيـام أحد بالطعن بالاستورية بعد صدورها، وذلك تأسيساً على عدم اتصالها بالمحكمة فى الأوضاع المقررة(') فيما ذهب فريق أخر إلى عدم ضرورة ذلك، إذ أن أشتراط ذلك الامر قد يـخلنا فى حلقة مفرغة، إذ قد تعرض النصوص مرة اخرى على المحكمة الاستورية فترى 
إنها مخالفة للاستور، فتعود أدراجها للتعديل وهكذا، كمـا ان حكم المحكمة بعدم القبول وفقاً للرأى الأول لامحل له إذ أن لا الاستور ولا القانون يمنع الطعن عليها مرة أخرى

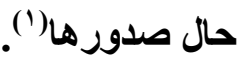
وقد أقترح البعض لتجنب ذلتك تبيـان المحكمة أوجـه عدم الاسـتورية عندما يعرض عليها لأول مرة، أو أن تقترح صياغة للنصوص المعيبة مباشرة، على أن يلتزم مجلس الشعب بهذه التعديلات حتى تتقق مع الدستور(). وهذا الجدل هو ما ثار حول المادة "VV" IV فى الدستور الجديد، وذلك لإغفالها هذا الفـرض، إلا أنتـا ومـن جاتبنـا نـرى ضـرورة عرضـها مـرة أخرى على المحكمـة الاستورية العليا، وذلك لأن نص المـادة قد أغلق صراحة الطعن على هذه القوانين

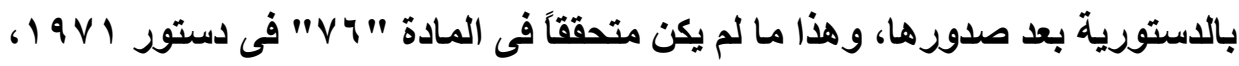

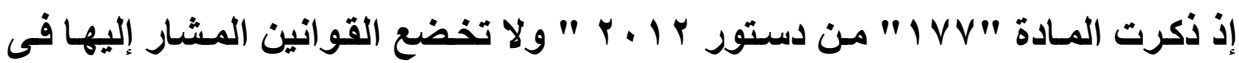
الفقرة الأولى للرقابة اللاحقة المنصوص عليها فى المادة "ه ا I من الدستور ". فوفقاً لهذه الفقرة من المادة أخرجت هذه القوانين من نطاق الرقابة اللاحقة، لذا وللتأكد من إتفاق النصوص القانونية مع الاستور، وجب إعادتها للمحكمة الاستورية العليا مرة أخرى للتأكد من ذلك. وقد حسم هذا الخلاف بإلغاء تعديل \& 1 ـ ب الرقابة السابقة على القوانين من قبل المحكمة الدستورية العليا، وهذا الأمر ما لا يمكن تفسيره، فالرقابة السابقة قصرت على 
القوانين الهامة كقوانين الإنتخابات الرئاسية والبرلمانية، وهذا ما كان يعد أمراً محموداً لخطورة هذه القوانين، ولمـا لهـا مـن أثـار قـد تلحق بالدولـة جراء بطلانهـا أو عدم

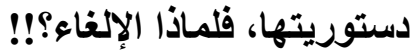
ومما سبق يتضح أن دور المحكمة الاستورية العليا يقتصر على مجرد التأكد من إتفاق القوانين من الاستور، وهذا ما لا يخالف مبأ الفصل بين السلطات، فالدستور الجديل بـالرغم من إعتناقه مبدأ الفصل بين السلطات صراحة، إلا أنه أقر إختصاص المحكمة الاستورية العليا بالرقابة على دستورية القوانين، مما لا يستقيم معه القول أن هذا الإختصاص يعد إهداراً لمبدأ الفصل بين السلطات.

\section{ويمكن تأسيس ذلك على العديد هن الاهور، هنها:}

أولاً: إن إلغاء تشريعًا أو إبطاله من قبل المحكمة الدستورية العليا، لا ينتقص من اختصاص السلطة التشريعية ولا ينال منها، إذ ان كافة سلطات الدولة تدور فى فلتك وحده الفكر القـانونى ووحدة وعلـو كلمـة الاسـتور، للذا وجب إعلائهـه مـن قبل كافـة

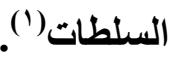

ثانيـا:أن رقابـة دستورية القوانين من قبل القضاء تعد عنصراً من عناصر أستقلال القضاء فى مواجهة السلطات الاخرى، إذ يمثل ذلك ضماناً لعدم فرض قانون غير دستورى من قبل السلطات الأخرى وإلزام القضاه بتطبيقه(؟).

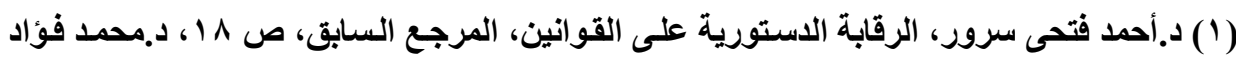

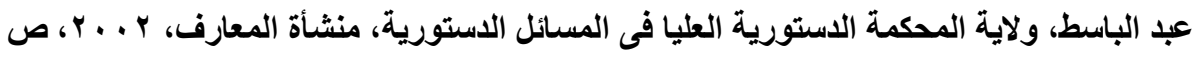

(2) Jacques cadart: Institutions politiques et droit constitutionnel, 1975, T1, p. 312. 
ثالثاً: إن القول بأن السلطة التثريعية منتخبة وهى ممثله الثعب، لذا لا يجب خضوعها للرقابة، لهو أمر محير فإن صفة الإتتخاب لا تنفى صفة القانون أو تضع مـا تصدره فى مرتبة أعلى من النصوص الاستورية. فـالقوانين حتى وإن صسرت مسن سـلطة منتخبـة فيجب ان تكون متفقـة مـع الاستور، إذ ان هذا الاخير أقر بإستفتاء الشعب عليه، أى أنه يعكس إرادتهم ورغباتهم، وهذا ما أكدته المحكمة الدستورية العليا ذاتها فى أحكامهاب(؟).

(1) حيث قضت" بأن الاستور لا يندرج في مفهوم القوانين التي تباشر المحكمة الاستورية العليا

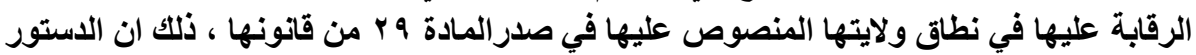

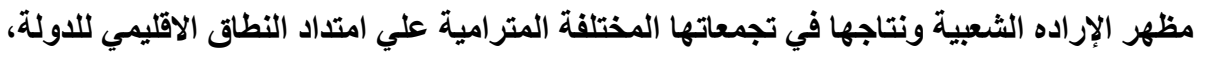

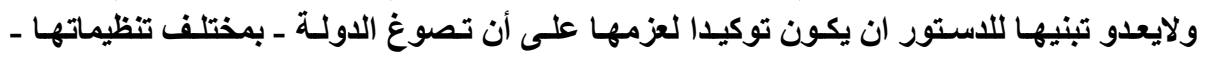

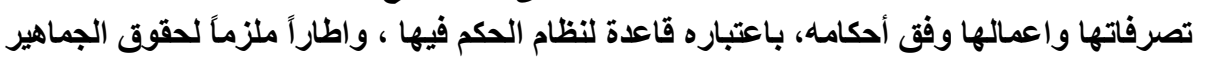

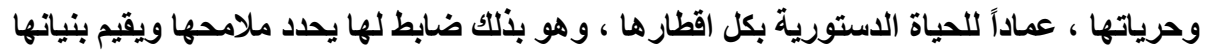

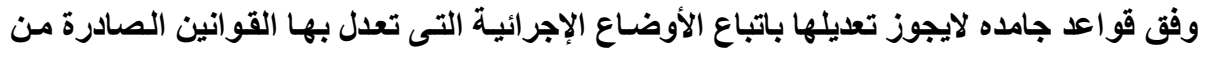

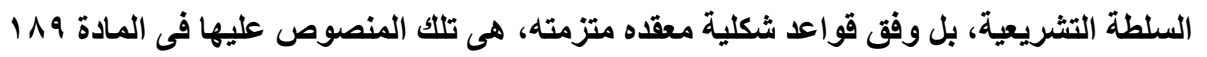

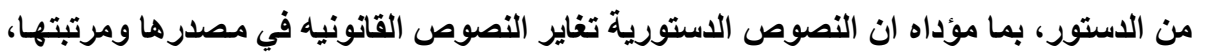

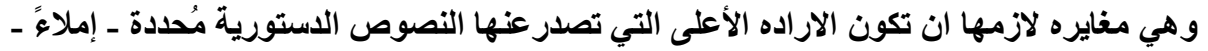

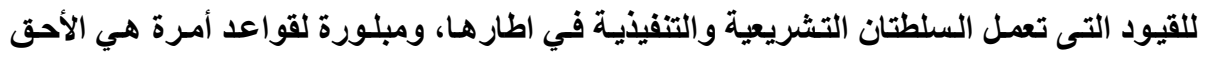

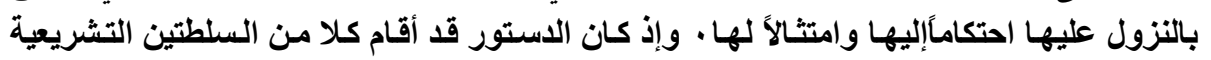

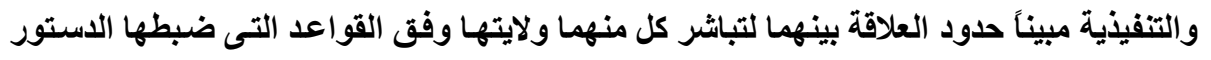

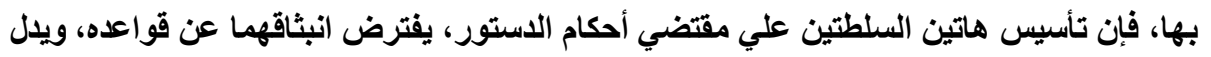

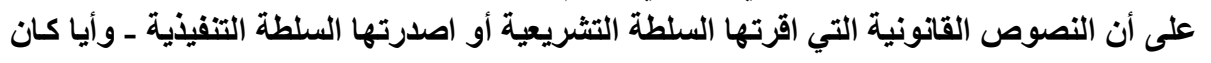

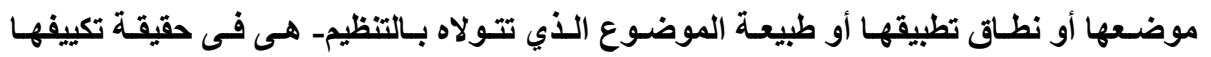

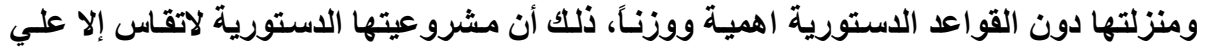

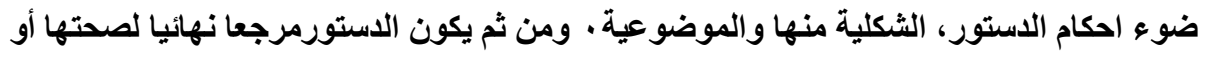

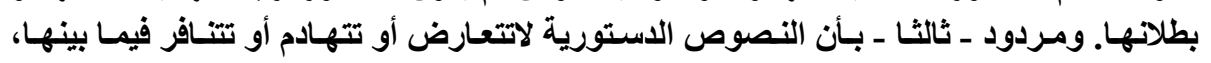

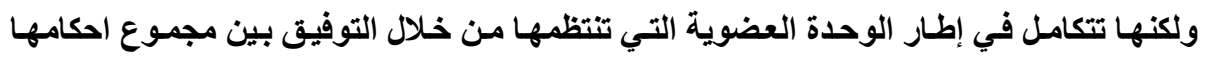
وربطها بالقيم العليا التي تؤمن بها الجماعة في مر احل تطور ها المختلفة. 
وأخيراً فإن القول بأن هذه الرقابـة تعد إهداراً للفصل بين السلطات، لا نجد مـا

يجدده سوى حكم المحكمة الاستورية ذاتها، حيث قضت "وحيث إن اختصاص السلطة التشريعية بـإقرار القواعد القانونيـة ابتـاع، وكـلك تفويـها السلطة التفيذيـة فى إصدارها فى الحدود التى بينها الدستور، لايخول إحداهما التدخل فى أعمـال أسندها

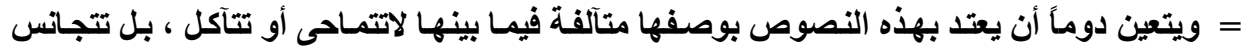

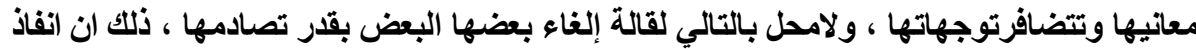

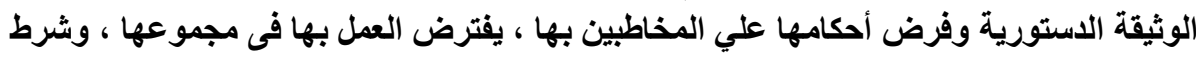

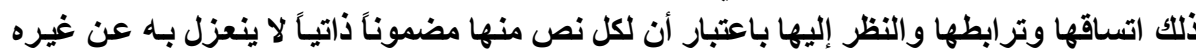

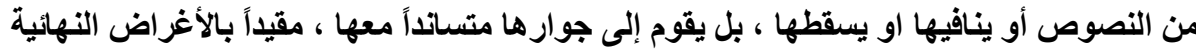

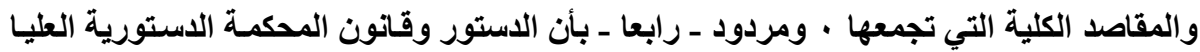

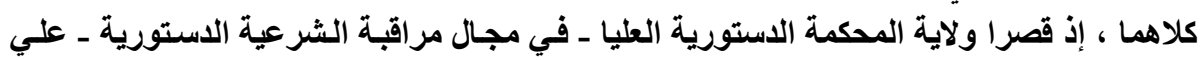

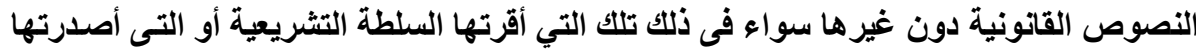

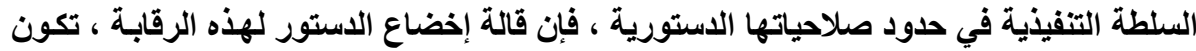

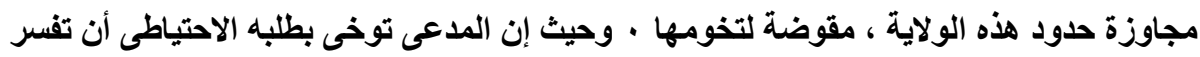

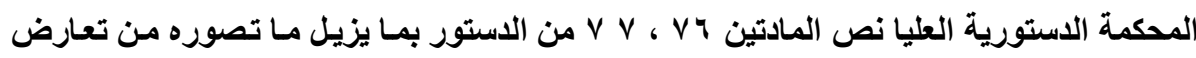

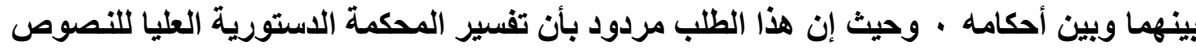

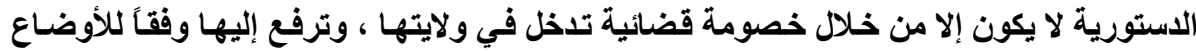

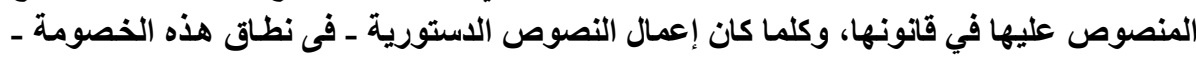

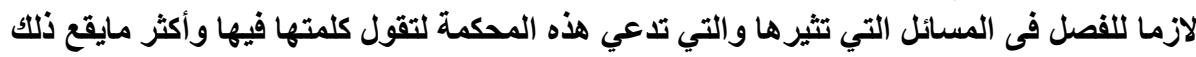

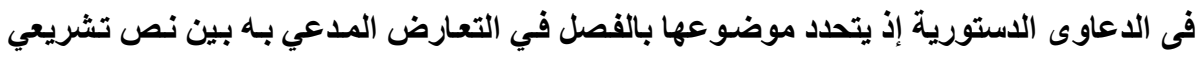

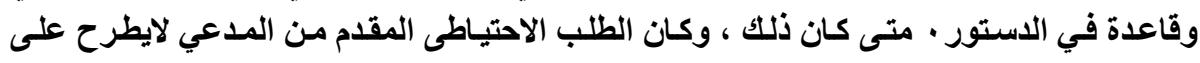

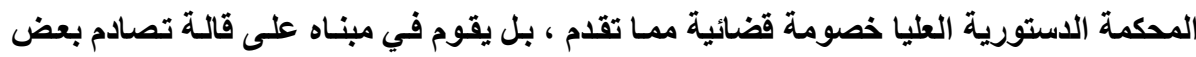

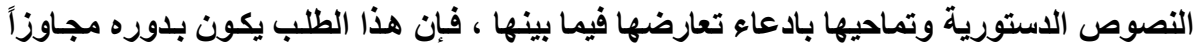

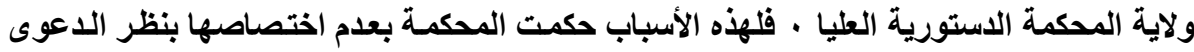

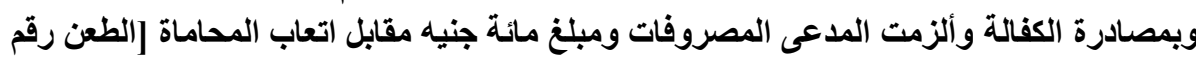

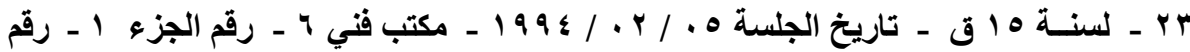


الاستور إلى السلطة القضائية وقصر ها عليها، وإلا كـان ذلك إفتئاتـا على ولايتها، وإخلالاً بمبدأ|لفصل بين السلطات"(') ومفاد ذلك أن إنكار رقابة دستورية القوانين من قبل القضاء، هو ما يمثل إهداراً لمبدأ الفصل بين السلطات، وذلك تأسيساً على أن الاستور قـ منحـه هذه السلطة صراحة، ومن ثم فإن حجبها يعد تلخل فى شئونها. وممـــــق كلـه يتـضح أن دور المحكمـة الدسـتورية العليـا فـى الرقابـة على دستورية القوانين، يعد من أهم دعائم مبدأ سيادة القانون، الذى تلتزم الدولة بموجبه

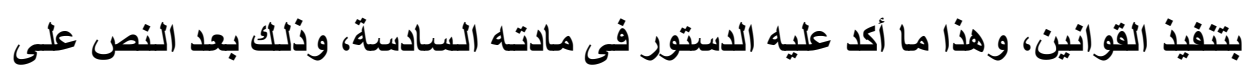
مبدأ الفصل بين السلطات فى ذات المادة. 


\section{الخاتهة}

يعد مبدأ الفصل بين السلطات مـن المبادئ التى أستقرت فـى غالبيـة أنظمـة الدولة، وإن أختلفت كل دولة فى تطبيقه عن الأخرى، لذا وجب معرفة أساسـه الفلسفى لفئ

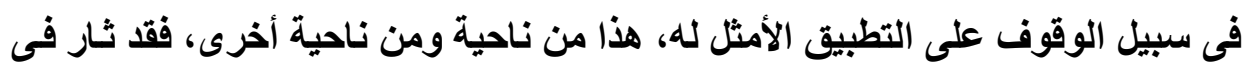

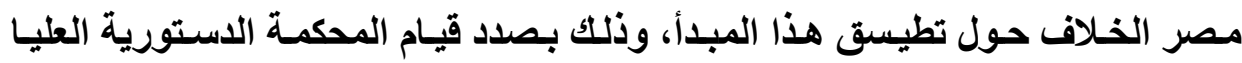
بدورها فى الرقابة على دستورية القوانين، وهذا مـا أستتبع تناول تطبيق المبدأ فى هي مصر فى ظل الاستاتير المختلفة، ودورالمكمة الدستورية العليا ومدى إهداره لمبدأ

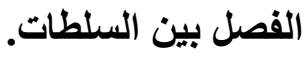

وفى سبيل تبيان ذلك تناولنا فكرة الفصل بين السلطات للاى فلاسفة الإغريق أفلاطون وأرسطو، وذلك لما لفلاسفة الإغريق من أثر حتى يومنا هذا. وقد تبين أن أفلاطون فى ظل قيامه برسم جمهوريته المثالية أهدر مبدأ الفصل

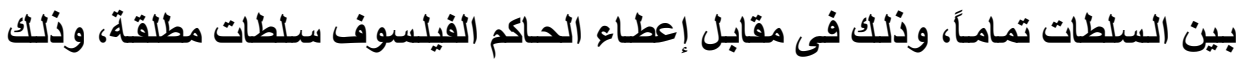
تحقيقاً للعدالة والنظام المثالى الذى أعثقده.

إلا أنه وبإصطامه بالو اقع من حيث صعوبة سيطرة الفلاسفة على الحكم، أقر مبدأ خضوع الكافة للقانون أى مبدأ سيادة القانون، وهذا مـا جعله ضمنياً يعرف فصل بالئل السلطات. - ات 
أما أرسطو فيرجع إليه تقسيم سلطات الدولة إلى ثلاث سلطات، حيث يعد أول

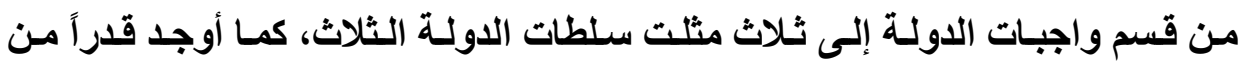
الرقابة و التعاون فيما بينهק.

وبالرغم من هذا إلا أن الفقه لم يرجع أساس مبدأ الفصل بين السلطات له، وذلك تأسيساً على أن هذا التقسيم لم يكن إلا تقسيماً وظيفياً لسلطات الدولة، فلم يكن تقسيم

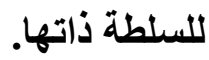

وقد سار على ذات النهج لوك الذى فصل بين السلطتين التشريعية والتفيذية للاولة، وأوجد نوعاً من الرقابة بينهما، و هذه المبادئ هى مـا تلقفها مونتسكيه ويلور مبدأ الفصل بين السلطات، وهذا ما أستبع إرجاع الأساس الفلسفى للمبدأ له. وقد صاغ مونتسكيه المبدأ بحيث تضمن وجود قدر من التعاون والرقابة بين سلطات الدولة الثلاث، بحيث عد هذا المبدأ صوناً لدرية الأفراد ومنع إستبداد أى هيئة من هيئات الاولة بالسلطة، وهذا مـا عكس الصورة المرنـة للمبدأ الذى دعى إليها

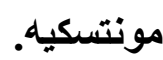
وبالرغم من ذلك إلا أن روسو قد خالف هذا المبدأ، وذلكك تأسيساً على نظريته عن السيادة وعدم قابليتها للتجزئة، فالسيادة من حق الشعب فقط ولا يجوز التنازل عنها أو تجزئتها، وهذا مـا أستتبع هيمنة السلطة المثلـه للشعب على كافة السلطات

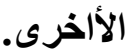

وقد وجد تطبيقاً لهذه الأفكار فى الأنظة المختلفة، فبينما أنتهج النظام البرلمانى الصوره المرنـة للمبدأ، أعتنق النظام الرئاسى الصورة الجامدة، فهى حين أن نظـام

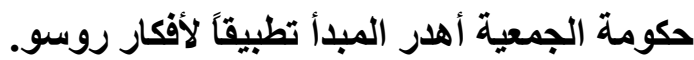


وتجدر الإثارة إلى أن التطبيق العملى لهذه الأسس قد أظهر إختلافاً عن المبادئ أو النصوص المقرره، فالفصل الجامد الذى أعتنقه النظام الرئاسى، قد تحول إلى فصل مرن مشوب بالتعاون، كما أن النظام البرلمانى قد أظهر إمكانية رجحان كفة سلطة على الجى أخرى فى التطبيق.

وفى مجال تطبيق هذا المبدأ فى مصر، فقد اتضح انتهاج الاساتير المختلفة لهه،

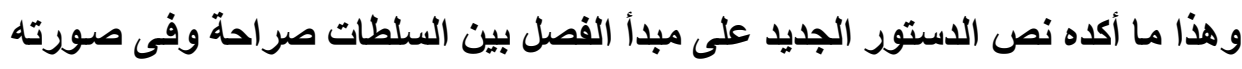
المرنة، وقد عكست قواعد تنظيم السلطات هذا المبدأ. كما ظهر أن دور المحكمة الدستورية العليا لا يتنافى مع المبدأ، بل أن هذا الدور

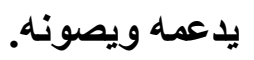

\section{وهن ذلك كله يمكن استخلاص ها يلى:}

أولاً: أن مبدأ الفصل بين السلطات يضرب بجذوره فى أعماق القلسفة اليونانية من

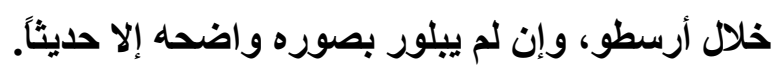

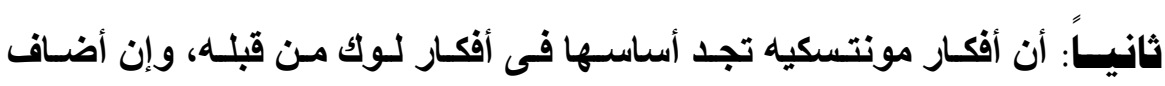
مونتسكيه على هذه الأفكار صابعاً خاصاً.

ثالثاً: أن أفكار مونتسكيه تبين أن مبدأ الفصل بين السلطات في صورته المرنة، هى ما يجب أن تسود وليس الفصل المطلق.

رابعاً: أن الدساتير المصرية قد أعتنقت مبدأ الفصل بين السلطات فى صورته

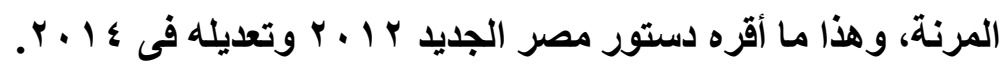


خاهسساً: أن نص الدستور بصدد تشكيل الحكومسة وتضمنه فرض تكوينها مـن

الحزب الحائز على الأغلبية، لزم إعـادة النظر فيه، وذلك تأسيساً على أن التطبيق العملى أظهر إمكان رجحان كفة السلطة التفيذيـة بنـاءً على وجود سند قوى لها ممثل فى الأغلبية البرلمانية. سادساً: أن دور المحكمة الدستورية العليـا فى رقابـة دستورية القوانين، لا يمثل إنتهاكاً لمبدأ الفصل بين السلطات، بل أنه يمثل صوناً وتطبيقاً له. سابعاً: أن مجلس النواب أو رئيس الدولة وجب عليهما عرض القوانين الخاصـه

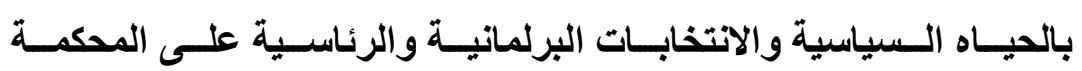
الاستورية العليا، كما يجب إعادة عرضها حال وجود ملحوظات عليها من قبل المحكمة، وذلك تأسيساً على أن الاستور قد حصنها حـال صدورها من الطعن، لذا لزم التأكد من اتفاقها مع الدستور. 


\section{المراجع

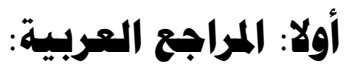

1

• د. إبراهيم درويش،النظام السياسى،دار النهضة العربية،الطبعة الرابعة، ^ \9 1 . • إبراهيم دسوقى أباظه، عبد العزيزالغتام،تاريخ الفكرالسياسى، بيروت، دارالنجاح، $.19 \vee 4$

• أبـن منظور،لسـان العرب المحيط، الجزءالرابـع، بيـروت دارالجليل ودار لسـان

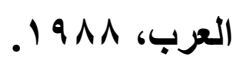

• د. احمد أمين ود. زكى نجيب، قصة القلسفة اليونانية، مكتبة النهضة المصرية،

الطبعة الثامنة.

• د.أحمـد كمـال أبـو المجـ، دراسـة فى القـانون الاسـتورى، دارالنهضة العربيـة،

$.19 \vee 0$

• د.أحمد وفيق، علم الدولة "فى أطوار فكرة الدولة"،الجزء الثانى، القاهرة، مطبعة

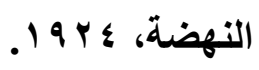

• أدمون ربـاط، الوسيط فى القـانون الاستورى العـام، الجزء الثانى، بيروت، دار

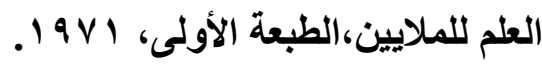

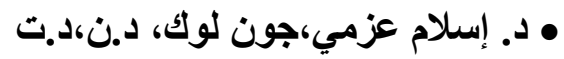

• د. السيد صبرى، الوزيرالأولفى إنجلترا، القاهرة، د.ن، V\& 9 ـ ـ 
• د. السـيد صـبرى،مبادئ القــانون الاسـتورى،المطبعة العالمية،الطبعـة الرابعـة،

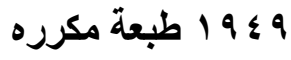

• د. السيد عبد الحميد فودة، النظريـة الاسـتورية للايمقراطية الإثينيـة، القـاهرة،

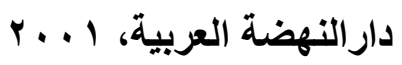

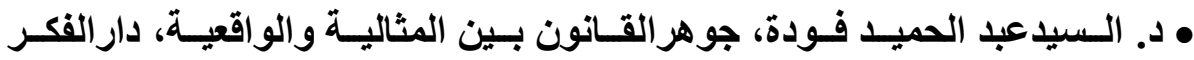

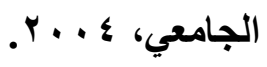

• د.امام عبد القتاح، الطاغية،الكويت،عالم الفكر، ؛ 99 • د. أميرةحلمي مطر،في فلسفة السياسة، دارالثقافة للنشر والتوزيع، بدون عام.

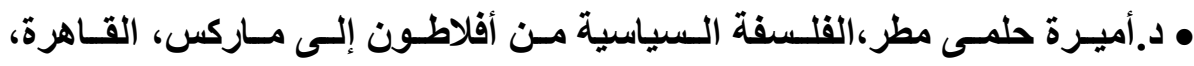
دارالمعارف.

• د.ثروت بـدوى، أصـول الفكر السياسى والمـاهب السياسية الكبرى، القـاهرة،

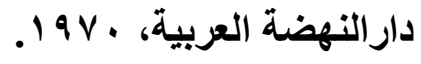

• د.ثروت بدوى،أصول الفكر السياسى، القاهرة، دارالنهضة العربية، Vج 9 ا ـ • د. حسن الظـاهز، دراسـات فـى تـاريخ الفكر السياسى، القـاهرة، مكتبـة الأنجل

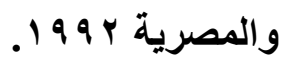
• د. حسن شـاته سعفان، اسـاطين الفكر السياسى والمـارس السياسية، القـاهرة، دارالنهضة العربية،

• د. حسين عثمان، النظم السياسية والقانون الاستورى، د.ن، 99 19 
• د.حوريـة مجاهد، الفكر السياسى مـن أفلاطون إلى محمد عبده، القـاهرة، مكتبـة

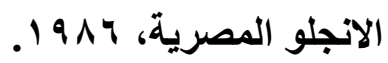

• رفقى زاهر، أعلام القلسفة الحديثة، القاهرة،المكتبة الحديثة، 9 و 9 ـ . • د.ربيع فتح الباب، النظام الدستورى المصرى"بيئته تطوره خصائصه وتنظيماته

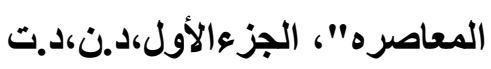

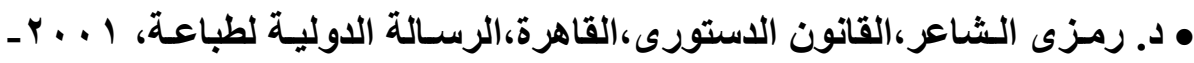

$$
r \ldots r
$$

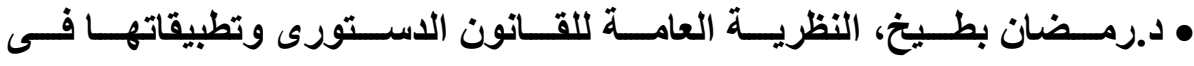
مصر،دارالنهضة العربية، الطبعة الاولى ه 99 1 ـ 999 19

• د. رمضان بطيخ، النظم السياسية والدستورية "دراسـة فى الوثائق المصرية

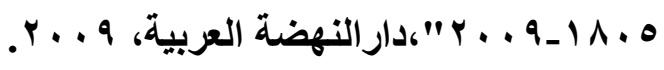

• د.سعاد الثرقاوى، النظم السياسية فى العالم المعاصر،الجزء الأول، القـاهرة، دار

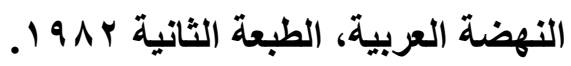

• د.سليمان الطماوى، السلطات الثثلاث فى الاسـاتير العربية المعاصرهو فى الفكر

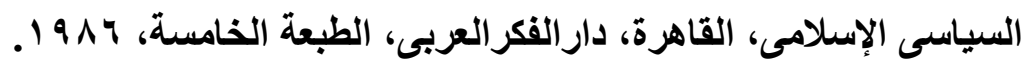
• د.طعيمة الجرف، نظرية الدولة والمبادئ العامـة للأنظمـة السياسية ونظم الحكم،

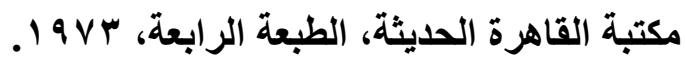
• د.طه بدوى، أصول علم السياسة، الإسكندرية،المكتب المصرى الحديث، الطبعة

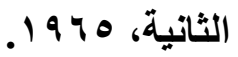


• د.طه عـوض غــازى، فكرة العدالـة فـى فلـسفة أقلاطون، القـاهرة، دارالنهضة

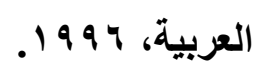

• د. عبد الحكم حسن العيلى،الحريات العامة فى الفكر والنظام السياسى فى الإسـلام

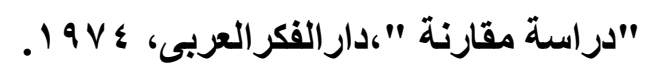

• د. عبدالحميـــ متـولى، الـوجيز فـى النظريــات والانظمـة الـسياسية، القـاهرة،

$$
\text { دارالمعارف، }
$$

• د. عبدالحميد متولى، أزمة الأنظمة الديمقراطية، الطبعة الثانية، ؛ ج 9 ـ. • د.عبد الحميد متولى، د.محسن خليل، د.سعد عصفور، القانون الاستورى والنظم السسياسية "مقومسات القـانون الاسـتورى، مـصـادرالقانون الاســتورى، رقابـة

$$
\text { دستورية القوانين" ،الإسكندرية، منشأة المعارف، د.ت. }
$$

• د.عبد الحميد متولى، القانون الدستورى والأنظمة السياسية، الإسكندرية، منشأة

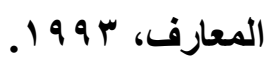

• د.عبد الكريم أحمد، بحوث فى تاريخ النظرية السياسية، معهد البحوث والدراسـات

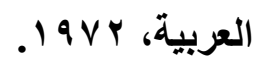

• د. عبد المنعم محفوظ، علاقة الفرد بالسلطة الحريـات العامـة وضمانات ممارستها

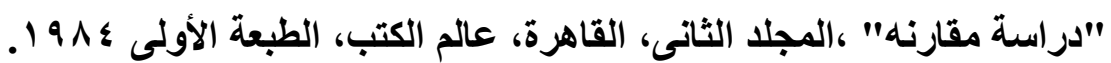
• د. على أحمـد عبـد القـادر، تطـور الفكرالسياسى، طا، القـاهرة، مكتبـة نهـة

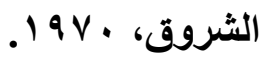


• د.على عبد المططى، الفكر السياسى الغربى، الإسكندرية، دار المعرفة الجامعية، .1911

• فتحى عبد الكريم، الدولـة والسيادة فى الفقه الإسلامى، القـاهرة، مكتبة وهبه، $.19 \wedge \varepsilon$

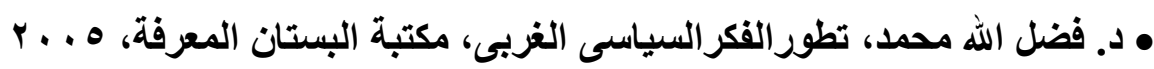
• د.فضل الله محمـد إسـماعيل، رواد الفكرالسياسى الغربسى الحديث، دارالجامعـة

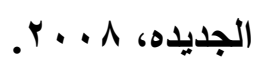

• د.فؤاد العطار، النظم السياسية والقانون الدستورى، القاهرة، دارالنهضة العربية، $.1974-1970$

• د.فؤاد زكريـا، جمهوريـة أفلاطون، الهيئة المـصرية العامـة للكتـاب، القـاهرة، .1910

• د. ماجد راغب الحلو، القانون الاستورى، دارالمطبوعات الجامعية، 1911. • د.ماهر عبد الهادى، السلطة السياسية فى نظريـة الدولة، القاهرة، دار النهضة العربية، ع ا9 الطبعة الثانية.

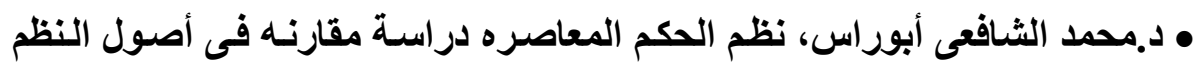
السياسية، الجزء الأول النظرية العامة فى النظم السياسية، القاهرة،عالم الكتب، $.191 \varepsilon$ • د. محمد بكرحسين، النظم السياسية "الدولة والحكومة، القاهرة، مكتبة السعادة، 
• د.محمد مرغنى خيرى، الوسبط فى النظم السياسية والقانون الاستورى المغربى،

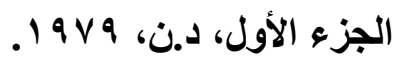

• د.محمد طه بـدوى، فلسفتنا السياسية والثوريـة، الإسكندرية، منشأة المعسارف،

$$
\text { د.تص،ص اس اسا }
$$

• د.محمد طـه بدوى،أصول علم السياسة،الإسكندرية، المكتب المصرى الحديث،

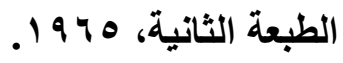

• د. محمــ على أبـو ريان،تـاريخ الفــر السياسى "القلـسفة اليونانيـة"، ، جا،

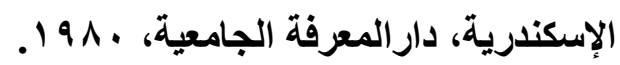

• د.محمد فتحى الشنيطى، نمـاذج من الفلسفة السياسية، مكتبة القاهرة الحديثة،

• د. محمد كامل ليلة، النظم السياسية الدولـة والحكومـة، دار النهضة العربية، عـام

• د. مصطفى أبو زيد فهمى، النظريـة العامـة للاولـة، الإسكندرية، منشـأة المعـارف،

$$
.1910
$$

• د. مصطفى خشاب، تـاريخ القلسفة والنظريـات السياسية، القـاهرة، لجنـة البيـان

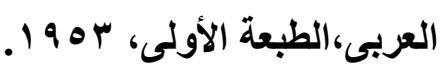

• د. ملحم قربـان، قضايا الفكر السياسي العدالـة، المؤسسسة الجامعيـة للاراسـات

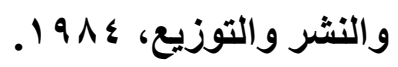


• د. نبيله عبد العليم، الرقابـة على دستورية القوانين "القضاء الاستورى" ،دار

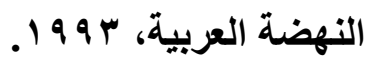

• د. وحيد رأفت، د. وايت إبراهيم، القانون الاستورى، القاهرة، المطبعة العصرية، $.194 \mathrm{~V}$

• د. يوسف كرم،تاريخ القلسفة اليونانيـة، لجنة التأليف والترجمة والنشر، الطبعة السادسة.

\section{r-الرسائل والمقالات:}

• أ.إبراهيم الصغير إبراهيم، مبدأ الفصل بين السلطات بين النظرية والتطبيق، مجلة

إدارةهيئة قضايا الحكومسة، السنة الرابعـة والعشرون، العـدد الثالـث يوليـو -

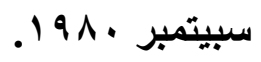

• دـ إبـراهيم على صـالح، المحكمـة الدسـتورية العليـا بـين الإبقـاء والإلغـاء، مجلـة

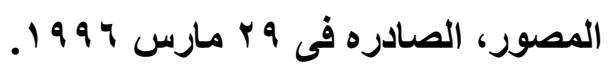

• رسالتنا للاكتوراه، التأصيل التاريخى والفلسفى لفكرة الديمقراطية، حقوق عين

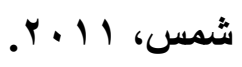

• د.أحمد حافظ نجم، الفصل بين السلطات وتطور العلاقة بين السلطات التشريعية والتنفيذية فى الدساتير المصرية، مجلة العلوم الادارية، السنة الثالثة والعشرون،

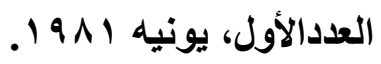

• د. أحمد سـلامة بلدر، الاختصاص التشريعى لرئيس الدولـة فى النظـام البرلمسانى

$$
\text { "دراسة مقارنة"،رسالة دكتوراه حقوق عين شمس، ب . . ب. }
$$


• د.أحمد شوقى محمود، الرئيس فى النظام الدستورى للولايـات المتحده الأمريكية، رسالة دكتور اه،

• د.أحمد فتحى سرور، الرقابة على دستورية القوانين، مجلة هيئة قضايا الدولة، السنة ؟ ب،مارس 999 19 1، العددالأول.

• د.أحمد كمـال أبو المجد، ضـمانات مبدأ المشروعية، العدد V،د، السنة التاسـعة

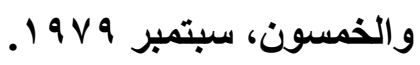

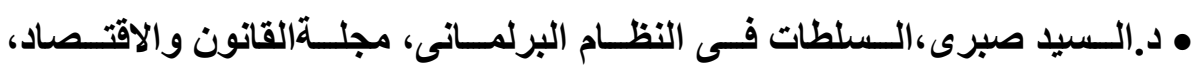

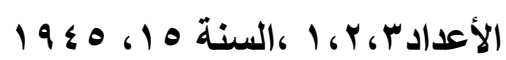

• د. السيد صبرى، السلطات فى النظام البرلمسانى، مجلة القـانون والاقتصاد، السنة الخامسة عشرة، الأعداد الاول والثانى والثالث، يناير فبراير مارس، 0 ؛ 9 ـ . • ـ ـ أنور احمد رسلان، الديمقراطية بين الفكر الفردى والفكر الإشتراكى، رسـالة

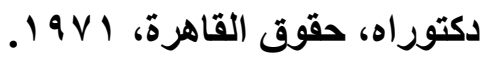

• ـ د.سـال محمود أحمد، مبـأ الفصل ببين السلطات فى النظـام السياسى الأردنى "دراسة مقارنة"،رسالة دكتور اه،حقوق عين شمس، V . . . .

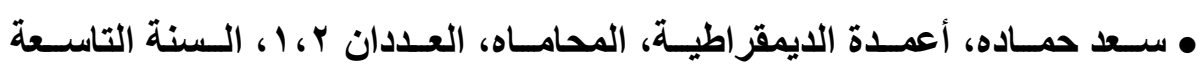
والخمسون، يناير- فبراير، 9 و 9 و • د. سعيد السيد صالح، حقيقة الفصل بين السلطات فى النظام السياسى والاستورى للولايات المتحده الأمريكية، رسالة دكتوراه عين شمس، 999 19. 
• ،د. عبد السلام ذهنى، ووايت إبراهيم، الانظمـة الدستورية والإداريـة والقضائية

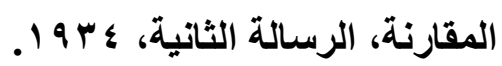

• د. علاء الدين سـد خطاب، التطور التاريخى لمبدأ الفصل بين السلطات، رسـالة دكتوراه، حقوق القاهرة، ..... - د.

• د.فوزية عبد الستار، الرقابة السابقة وتحصين القوانين، جريدة الأهرام، العدد

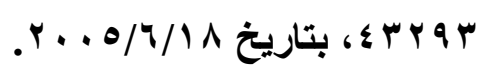

• د.محمد عبد اللطيف، الرقابـة السابقة وتحصين القوانين، جريـدة الأهرامـا لعدد

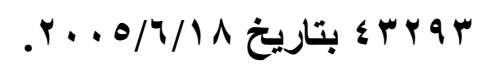

• د. محمد على الصافوري، أراء أفلاطون في القـانون والسياسة، بحث منشور بمجلـة البحـوث القانونيـة والاقتـــادية التـي تـصدر ها كليـة الحقـوق - جامعـة

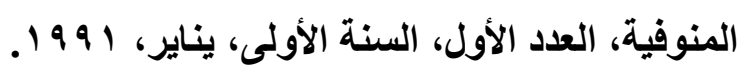
• د.محمد فؤاد عبد الباسط، ولاية المحكمة الدستورية العليا فى المسائل الاستورية،

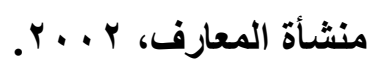

• د.محمـود عـاطف البنـا، الاسـتور الجديــ ومبـدأ الفـصل بـين السلطات، المجلـة المصرية للعلوم السياسية، العدد \& 197 مايو يونيه 197 .

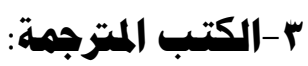

• أرسطو، السياسة،الكتاب السـادس،الباب الحـادى عشر فقرة " ا"“ترجمـة أحمد

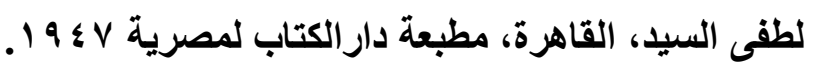


• أرنست بـاركر، النظريـة السياسية عنداليونان، ترجمة لـويس إسكندر، بيروت،

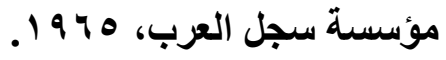

• أفلاطون، الجمهوريـة، ترجمـة فؤاد زكريـا، القـاهرة، المؤسسة العامـة للتـأليف

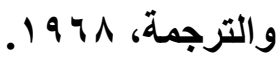

• أندريه كريسون، تيارات الفكر القلسفى منا لقرون الوسطى حتى العصر الحديث، ترجمة نهاد رضا، لبنان، بيروت، منشورات عويدات، د.ت.

• أندريه هوريو، القانون الاستورى والمؤسسـات السياسية، الجزء الأول، ترجمة

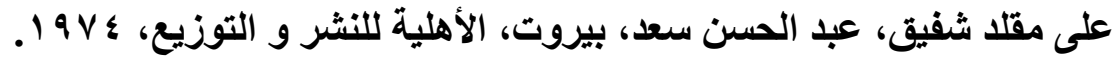
• برتزانــ رسل، تـاريخ الفلسفة الغربية، الكتاب الثالث، القلسفة الحديثة، ترجمـة د.محمد فتحى الثنيطى، القاهرة، الهيئة المصرية العامة للكتاب، 9VV I . • جانتوشـار،تاريخ الفكر السياسى، الدار العالميـة للطباعة والنشر،الطبعة الثانيـة،

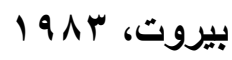
• جانج اكثوفالييه، تاريخ الفكر السياسي، ترجمة د. محمد عربص اصيلاً، بيروت، المؤسسة الجامعية للاراسات والنشر والتوزيع، ه19 1 . • شوف الييه، المؤلفات السياسية الكبرى من مكيافيللى إلى أيامنـا، ترجمة إلياس

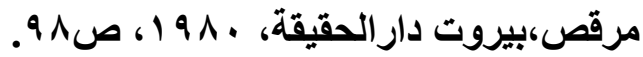
• جورجسباين، تطور الفكر السياسى،ترجمة حسن جـلال العروسس،، تصدير د.عبد الرزاق السنهورى، وتقديم د.عثمان خليل، القاهرة، دارالمعارف، الطبعة الثالثة، 
د/ أحمد على ديهوم

القلــسفة،ترجمة أنورعبــــ الله، الدار المــصرية

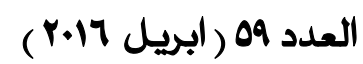

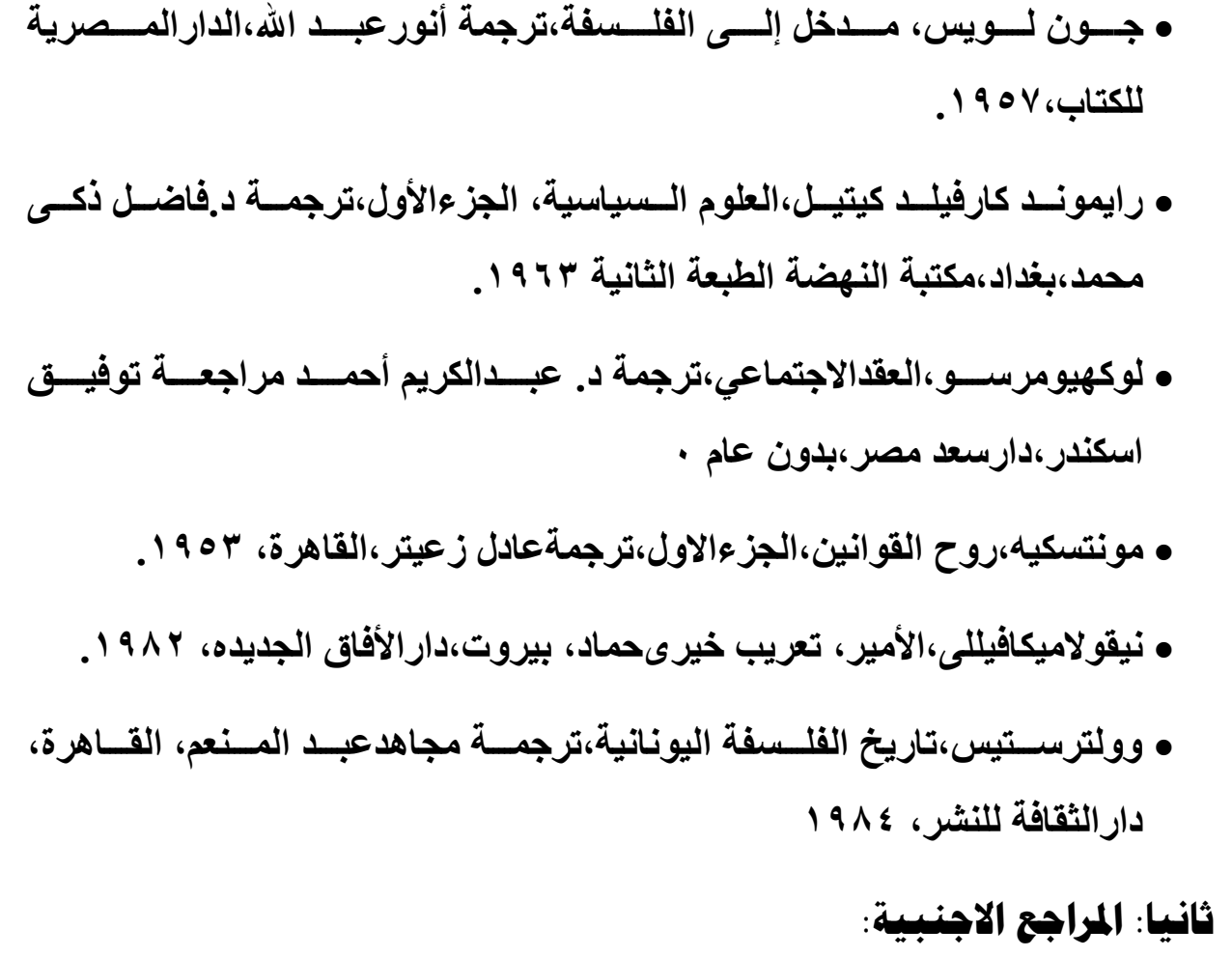

- Albert Brimo:Les grands courants de la philosophie du droit et d l etat, paris, 1967.

-A.C. Kapaor: Principles of political scierce, New delhi press, 1987.

- BarthelemyetDuez: Trait de droit constitutionnel, paris, 1920.

- Barthelemy: Traiteelementaire de droit constitutionnel. 1933.

مجلت البحوث القانونيتً والإقتصاديت 
د/ أحمد على ديهوم

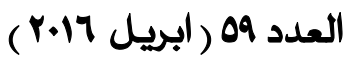

- burdeau: Manuel droit constitutionnel et institutions politiques, paris, 1959.

- Carre de malberg: contribution a le theoriegenerale de I etat, 1920, T1, T2.

- Del vecchio:philosophie du droit, Dalloz, 1953.

- Duguet: Lecons de droit public General, paris, press universitairs de france, 1976.

- Duguet: Siverainiteetliberte, parissirey 1922.

- Ellul"Jacques": Histoire des institutions, tome premier, 1955.

- Esmein(A): Elements de droit constitutionnelFrancais et compare, tom 1, paris, 1927.

- F.W.coker: Reading in political philosophy, U.S.A, macmillan co, 1959.

- G.D.H.cole, Essays in the social theory, London old banrne science library, 1962.

- Henri Rommen: Le droit naturel, Traduction par Emile Marny, paris.

• Impert "Jean": Le droit antique, 3e edition 1976.

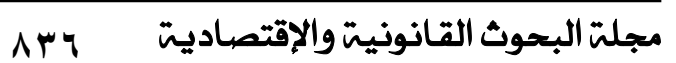


- Sir Ivor Jennings: The law and The constitution, London, fifth edition, E.L.B.S, 1979.

- J.Maillet:Histoire des institutions et des faitssociaux, dalloz, 1956.

- Jacques cadart: Institutions politiqueset droit constitutionnel, 1975, T1.

• Jeanniere"Abel": Lire platon, Edition de Aubien.

- Jean brun: platonet I academie, paris, 1960.

- Karminck Isaac "Editor": Essays in the history of political thought, New jersey prentice hall Englewood clifs, 1969.

- Locke:Essay concerning the true origin, Extene and end of civil Government, London, Allen \& unwin, 1960, p.68

- Locke, Hume, Rousseau: Social contract, London, oxford university press, 1948.

- M.Humbert:Institutionspolitiques et sociales de I antiquite, 1994.

- Michel villey: la formation de la penseejuridique modern, paris, 1968. 
د/ أحمد على ديهوم

العدد 09 ( ابريل 17 (1) )

- Montesquieu: The spirit of laws, translated by Thomas Nugent, new York, hadner publishing, co, 1949.

- P.c.Timbel: Histoire des institution, dollaz, 1966.

- Rousseau: Social contract, oxford university press, 1948.

- Sabine: A History of political theory, New York, holt, 1946.

- S.Plamkrechf: The Moral and political philosophy of J.locke, Newyork, the macmillan ca, 1961.

- T.A.Sinclain: Histoire de la penseepolitiqueGreceque, paris, 1953.

- Vedel "G": Manuel elementaire de droit constitution, paris, 1949.

-W.T.jones: Masters political though, boston, houghter Mifflin, 1941.

- William Ebnestien: Great political Thinkers from plato to the present, Illinis, Dryden, press, 1969. 